\title{
Photodynamic Therapy and Hyperthermia in Combination Treatment-Neglected Forces in the Fight against Cancer
}

\author{
Aleksandra Bienia (D, Olga Wiecheć-Cudak, Aleksandra Anna Murzyn and Martyna Krzykawska-Serda *(D) \\ Faculty of Biochemistry, Biophysics and Biotechnology, Jagiellonian University, 30-387 Kraków, Poland; \\ aleksandra.bienia@student.uj.edu.pl (A.B.); olga.wiechec@doctoral.uj.edu.pl (O.W.-C.); \\ aleksandra.murzyn@doctoral.uj.edu.pl (A.A.M.) \\ * Correspondence: martyna.krzykawska@uj.edu.pl
}

\section{check for} updates

Citation: Bienia, A.; Wiecheć-Cudak, O.; Murzyn, A.A.; Krzykawska-Serda, M. Photodynamic Therapy and Hyperthermia in Combination Treatment-Neglected Forces in the Fight against Cancer. Pharmaceutics 2021, 13, 1147. https://doi.org/ 10.3390/pharmaceutics 13081147

Academic Editors: Gabriela

Romero Uribe, Sergio Moya and Twan Lammers

Received: 18 May 2021

Accepted: 16 July 2021

Published: 27 July 2021

Publisher's Note: MDPI stays neutral with regard to jurisdictional claims in published maps and institutional affiliations.

Copyright: (c) 2021 by the authors. Licensee MDPI, Basel, Switzerland. This article is an open access article distributed under the terms and conditions of the Creative Commons Attribution (CC BY) license (https:// creativecommons.org/licenses/by/ $4.0 /)$.
Abstract: Cancer is one of the leading causes of death in humans. Despite the progress in cancer treatment, and an increase in the effectiveness of diagnostic methods, cancer is still highly lethal and very difficult to treat in many cases. Combination therapy, in the context of cancer treatment, seems to be a promising option that may allow minimizing treatment side effects and may have a significant impact on the cure. It may also increase the effectiveness of anti-cancer therapies. Moreover, combination treatment can significantly increase delivery of drugs to cancerous tissues. Photodynamic therapy and hyperthermia seem to be ideal examples that prove the effectiveness of combination therapy. These two kinds of therapy can kill cancer cells through different mechanisms and activate various signaling pathways. Both PDT and hyperthermia play significant roles in the perfusion of a tumor and the network of blood vessels wrapped around it. The main goal of combination therapy is to combine separate mechanisms of action that will make cancer cells more sensitive to a given therapeutic agent. Such an approach in treatment may contribute toward increasing its effectiveness, optimizing the cancer treatment process in the future.

Keywords: photodynamic therapy (PDT); hyperthermia; chemotherapy; radiotherapy; surgical intervention; cancer; combination therapy; hypoxia; drug delivery

\section{Introduction: Aims of Anti-Cancer Combination Therapy}

Cancer is a disease that is increasingly affecting our society. It is one of the reasons for high mortality across the world. Cancer is a leading cause of death worldwide, and is ranked as first or second in noncommunicable diseases (NCD) in developed countries [1]. In the majority of cases, current cancer treatments are not effective. In 2020, the estimated numbers of new cancer cases amounted to more than 1.8 million, and an estimated 0.6 million cancer-related deaths were predicted [2]. These numbers indicate that 1 of 3 cancer patients die from the disease [2]. Common treatment options include surgical intervention, chemotherapy, and radiotherapy. For some types of cancer, there are new, more popular treatment methods (e.g., immunotherapy for melanoma) [3]. Anti-tumor therapeutic problems include systemic toxicity, pain, reduced immunity, and anemia (it depends on the treatment used). Hence, treatment dosages should be high enough to fight cancer cells, and, at the same time, low enough to prevent serious side effects. The question is: where do cancer cells develop resistance to treatment? The resistance of cancer cells to the administered drugs/radiation and the high toxicity of systemic therapy have contributed to the development of new approaches in cancer treatment. Therefore, attempts have been made to combine various available methods that are used to treat tumors. The main goal of this strategy is to combine different mechanisms of action that lead to sensitizing cells to the next therapeutic factor. Thus, combination therapy is promising for patients, due to the fact that it contributes toward increasing the effectiveness of cancer treatment, and reducing the toxicity for normal cells (as a result of lowering chemotherapeutic doses). 


\subsection{Combination Treatment-Definition, Pros, and Cons}

Combination therapy is defined as a form of therapy where a minimum of two standard forms of therapy are applied. The most common combination therapy is, likely, the application of two chemotherapeutics drugs. However, it is the same type of therapy. The most common combination of different types of therapies is the application of chemotherapy and radiation therapy. Combination therapy offers the most effective treatment results. By using this method, greater treatment effectiveness is achieved, and the toxic effects of chemotherapeutic agents is reduced (Figure 1). The results of the applied combination therapy can be additive or synergistic. Their advantages stem from the fact that anti-cancer treatment is targeted at many biological pathways. In addition to cancer treatment, slowing down tumor development, as well as reducing the resistance of tumors to, e.g., chemotherapy or radiation therapy, is also possible. This approach can have much greater results than using monotherapy. It is postulated that cancer cells are often unable to adapt to the simultaneous harmful effects of two therapeutic methods [4]. This requires answering more questions and having deep knowledge about standard therapy and combinatory results.

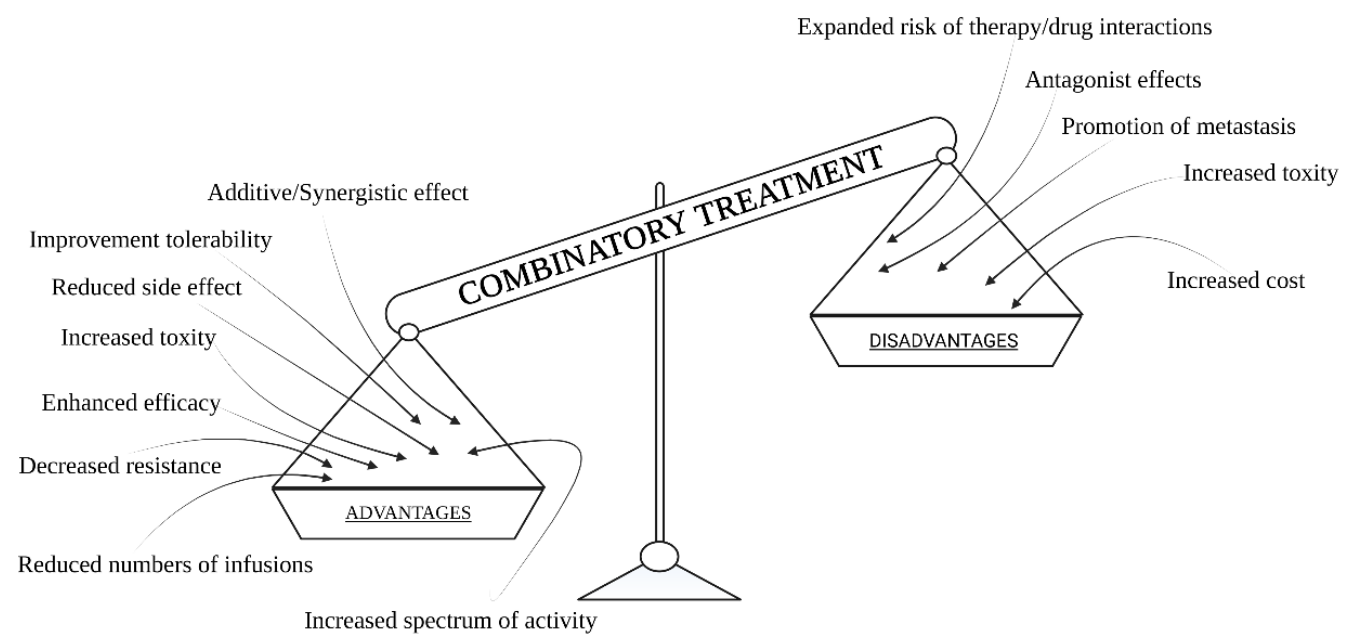

Figure 1. Pros and cons of combination treatment.

In addition to killing cancer cells, targeting different pathways through a combination of treatment techniques can reduce the risk of cancer cells becoming more aggressive and resistant [4]. The undoubted advantage of this strategy is the possibility of achieving such an optimization of treatment elements where, in general, the therapy can be targeted against the particular mechanism. Resistance to the drugs used can be reduced, which was already mentioned before, but it also reduces aggressiveness and metastasis, which contributes to the increase in the effectiveness of fighting cancer. The multi-module approach allows consideration of the heterogeneity of cancerous tumors, which increases the chance of killing all cancer cells. Most importantly, it proves a chance to kill cancer stem cell populations that are known to contribute to drug resistance and cancer recurrence after remission in later years [5,6]. Combination therapies can also reduce side effects by lowering doses of individual monotherapies. Unfortunately, combining different treatments can increase harm to the patient [7]. It is worth emphasizing the further side effects of using photodynamic therapy and hyperthermia. Another important issue is the promotion of metastasis due to increased permeability [8]. However, it is not a simple matter. This is a fairly complex problem. It is important to note that a cancer cell must survive after treatment and be able to pass through the blood vessels within the tumor, and then must survive in a completely different niche, which is not a straightforward matter.

This can make it difficult to identify the agent responsible, and may result in the difficulty to assess which agent's dose should be reduced. If therapeutic agents work similarly and their side effect profiles are similar, the accumulation of side effects can cause more severe clinical symptoms [4]. The problem (and, at the same time, disadvantage) of 
using combination therapy is the cost of such therapy. It is widely known that the use of monotherapy is much cheaper than the use of two or even more treatment methods. In addition, there are some questions about the method of maximizing the use of more than one therapy. These questions are related to identification of a "therapeutic window": what time is best to apply the second stage of treatment in order to maximize benefits? Next, which method should be the leading one, and when should we start each therapy in order to achieve the best results? The issue of using combination therapy is an individual matter and it all depends on the tumor vasculature and the type of cancer, but thanks to the individual approach, and combination of various methods suitable for a given type and stage of cancer, we can achieve surprising results. It is especially important to understand the interaction between two or more anti-cancer agents in a combination regimen to obtain maximum efficacy with the least toxicity. To conclude, the new quality of combination treatment emerges from the selected anti-cancer agents for particular tumors and evolves in the time scale. It requires deep knowledge about treatment mechanisms. On the other hand, there are many combinatory protocols already used in clinics, and they are applied successfully without good understanding of the mechanisms of action.

\subsection{Action Strategies and the Greatest Successes in the Fight against Cancer}

In the context of the use of combination therapies in cancer treatment, there are some very interesting results obtained by the use of chemotherapy, radiotherapy, hyperthermia, photodynamic therapy or surgery, and immunotherapy in various combinations. Currently, a combination treatment of chemotherapy, radiotherapy, and often surgery is used commonly in cancer treatment. With this approach, we can effectively stop cancer development and obtain the best possible results based on current knowledge (but one of three cancer cases still lead to patient death). There is no doubt that combination treatment provides very good results, as opposed to using only one method due to the comprehensiveness of the multi-module treatment. Based on many simulations with the use of computer models, cancer treatment strategies were optimized using a combination of possible treatments [9-11]. The crucial elements for optimization are drugs and their doses, as well as the dose of light and radiation, in the context of cancer type and the degree of its aggressiveness. Fractionation of the radiation dose also proved to be more crucial, giving better results [12,13].

In addition, cutting out cancerous tissue, with a margin of healthy tissue, combined with chemotherapy cycles, provides the best results and reduces tumor metastasis. It also allows for targeted treatment and effectiveness increase due to a long-term and selective action. Taking into account the occurrence of cell cycles and cell resistance at various stages of the cell cycle for selected methods, it offers more significant results. Scientific research has also shown that the cells present in the phase that is the most resistant to radiation, i.e., those that are in the $S$ phase (replication phase), are also very sensitive to hyperthermia [14]. Therefore, it was concluded that hyperthermia allows sensitization of cells to X-rays in the further treatment phase [15]. When considering combination therapy, one may come across concepts, such as thermochemotherapy, thermoradiotherapy, and thermochemoradiotherapy. Considering thermoradiotherapy, the general mechanism of action is primarily the possibility of destroying cancer cells that are insensitive to radiation. It also inhibits the process of repairing damage to DNA under the influence of a dose of ionizing radiation. Due to this approach, combination therapy in cancer treatment offers more effective therapeutic results. In turn, analyzing the introduced concept of thermochemotherapy in the treatment of cancer, one may observe an increase in sensitivity and reduction in cancer cell resistance to chemotherapy. With this approach, it is possible to increase the accumulation of chemotherapeutics in the cancer location $[15,16]$. All of this contributes toward increasing the effectiveness of this complementary method, which, in this context, has been linked to phenomena, such as hyperthermia. Undoubtedly, new classes of chemotherapeutics, as well as various mechanisms of action of drugs, such as the use of drugs that are not dependent on the rate of proliferation, or those that depend on 
the phase of the cell cycle, and attempts to combine drugs with non-overlapping toxicity, or a use of a combination of drugs that have different mechanisms of action [17], as well as the way of adding drugs, for example using targeted liposomes, significantly improve the effects of treatment and show us the importance of using combination therapy. On the other hand, the use of thermochemoradiotherapy shows that multi-module treatment brings the most beneficial and the best results [18]. Researchers have studied the interaction between hyperthermia and radiation therapy, as well as chemotherapy using chemotherapeutic agents, such as cisplatin. Scientific research has shown that a synergistic effect can be obtained, but only when this three-modular therapy is used on cell lines that are not resistant to cisplatin $[19,20]$. Considering photodynamic therapy, this combination of therapy with chemotherapy gives quite good results due to direct destruction of cancer cells and strong influence on blood vessels in the tumor surrounding. It was shown that different PDT protocols can significantly damage the vasculature or temporally increase blood flow and tissue oxygenation in the treated area [21]. However, as a result of photodynamic therapy, when not all of the cells are destroyed, the use of chemotherapy in the second wave allows killing the remaining cancer cells that have survived PDT. Additionally, it was shown that PDT can have strong influence on the immune system [22]. With this approach, combining methods can stop the cancer or lead to a complete cure.

The list of combination therapies (with mixed treatment types) conducted in 2015-2020 was presented in Table 1. The data are presented only for the four most common cancers in the world according to GLOBOCAN 2018 [1] and for pancreatic cancer, which was chosen due to our interest.

Table 1. Completed, combined anticancer therapies; study started in the years 2015-2020 (ClinicalTrials.gov).

\begin{tabular}{|c|c|c|c|c|c|c|c|}
\hline Cancer & $\begin{array}{l}\text { Combination } \\
\text { Therapy Scheme }\end{array}$ & Trial Design & $\begin{array}{l}\text { Clinical } \\
\text { Stage }\end{array}$ & $\begin{array}{l}\text { Median OS * } \\
\text { (Months) }\end{array}$ & $\begin{array}{l}\text { Median PFS* } \\
\text { (Months) }\end{array}$ & $\begin{array}{l}\text { ClinicalTrial.gov } \\
\text { ID }\end{array}$ & Ref. \\
\hline $\begin{array}{l}\text { Non-small cell } \\
\text { lung cancer stage } \\
\text { III }\end{array}$ & $\begin{array}{l}\text { Chemoradiotherapy } \\
\text { and } \\
\text { immunotherapy }\end{array}$ & $\begin{array}{l}\text { cis-/carboplatin + vinorelbine } \\
\text { + etoposide/pemetrexed, } \\
\text { radiation, and Nivolumab }\end{array}$ & II stage & 38.8 & 12.7 & $\begin{array}{l}\text { NCT02434081 } \\
{[23]}\end{array}$ & {$[24,25]$} \\
\hline $\begin{array}{c}\text { Unresectable } \\
\text { non-small cell } \\
\text { lung cancer }\end{array}$ & $\begin{array}{l}\text { Chemotherapy and } \\
\text { radiotherapy }\end{array}$ & $\begin{array}{l}\text { Vinorelbine, Cisplatin, and } \\
\text { radiation }\end{array}$ & II stage & 35.6 & 11.5 & $\begin{array}{l}\text { NCT02709720 } \\
{[26]}\end{array}$ & [27] \\
\hline $\begin{array}{l}\text { Small cell lung } \\
\text { cancer }\end{array}$ & $\begin{array}{l}\text { Chemotherapy and } \\
\text { immunotherapy }\end{array}$ & Paclitaxel and Pembrolizumab & II stage & 9.2 & 5.0 & $\begin{array}{c}\text { NCT02551432 } \\
{[28]}\end{array}$ & {$[29,30]$} \\
\hline $\begin{array}{l}\text { Non-small Cell } \\
\text { Lung Cancer }\end{array}$ & $\begin{array}{l}\text { Chemotherapy and } \\
\text { immunotherapy }\end{array}$ & $\begin{array}{c}\text { Carboplatin/Paclitaxel and } \\
\text { SB8 (A proposed bevacizumab } \\
\text { biosimilar) } \\
\text { Carboplatin/Paclitaxel and } \\
\text { Bevacizumab }\end{array}$ & III stage & $\begin{array}{l}14.90 \\
15.80\end{array}$ & $\begin{array}{l}8.5 \\
7.9\end{array}$ & $\begin{array}{c}\text { NCT02754882 } \\
{[31]}\end{array}$ & [32] \\
\hline $\begin{array}{l}\text { Non-small Cell } \\
\text { Lung Cancer }\end{array}$ & $\begin{array}{l}\text { Chemotherapy and } \\
\text { immunotherapy }\end{array}$ & $\begin{array}{c}\text { Nivolumab and Ipilimumab } \\
\text { EGFR } \\
\text { Nivolumab plus Ipilimumab } \\
\text { ALK } \\
\text { Experimental: Nivolumab + } \\
\text { Carboplatin + Pemetrexed } \\
\text { with EGFR chemo-naive } \\
\text { Nivolumab + Carboplatin + } \\
\text { Pemetrexed ALK chemo-naive }\end{array}$ & II stage & $\begin{array}{c}22.3 \\
7.6 \\
7.75 \\
5.9\end{array}$ & $\begin{array}{c}1.3 \\
0.7 \\
4.65 \\
2.8\end{array}$ & $\begin{array}{c}\text { NCT03256136 } \\
\text { [33] }\end{array}$ & - \\
\hline $\begin{array}{l}\text { Small cell lung } \\
\text { cancer }\end{array}$ & $\begin{array}{l}\text { Immunology and } \\
\text { radiotherapy }\end{array}$ & $\begin{array}{c}\text { Durvalumab and } \\
\text { Tremelimumab } \\
\text { Durvalumab and } \\
\text { Tremelimumab and } \\
\text { hypofractionated } \\
\text { radiotherapy/stereotactic body } \\
\text { radiation therapy }\end{array}$ & II stage & $\begin{array}{l}2.8 \\
5.7\end{array}$ & $\begin{array}{l}2.1 \\
3.3\end{array}$ & $\begin{array}{l}\text { NCT02701400 } \\
{[34]}\end{array}$ & {$[35]$} \\
\hline $\begin{array}{l}\text { Non-small cell } \\
\text { lung cancer }\end{array}$ & $\begin{array}{l}\text { Target therapy and } \\
\text { Immunotherapy }\end{array}$ & Ensartinib and Durvalumab & I/II stage & - & - & $\begin{array}{c}\text { NCT02898116 } \\
{[36]}\end{array}$ & - \\
\hline $\begin{array}{l}\text { Non-small cell } \\
\text { lung cancer }\end{array}$ & $\begin{array}{l}\text { Surgery and } \\
\text { immunotherapy }\end{array}$ & $\begin{array}{l}\text { Cryosurgery and NK } \\
\text { Immunotherapy }\end{array}$ & I/II stage & - & - & $\begin{array}{l}\text { NCT02843815 } \\
\text { [37] }\end{array}$ & [38]. \\
\hline Lung neoplasms & $\begin{array}{l}\text { Cryotherapy and } \\
\text { target therapy }\end{array}$ & Cryotherapy and Icotinib & IV stage & - & - & $\begin{array}{c}\text { NCT02744664 } \\
{[39]}\end{array}$ & - \\
\hline $\begin{array}{l}\text { Non-small cell } \\
\text { lung cancer }\end{array}$ & $\begin{array}{l}\text { Chemotherapy and } \\
\text { immunotherapy }\end{array}$ & $\begin{array}{c}\text { Atezolizumab and Carboplatin } \\
\text { and Paclitaxel (APC) } \\
\text { Atezolizumab, Bevacizumab, } \\
\text { Carboplatin, and Paclitaxel } \\
\text { (ABCP) } \\
\text { Bevacizumab, Carboplatin, } \\
\text { and Paclitaxel (BCP) }\end{array}$ & III stage & $\begin{array}{c}\text { In the ITT * } \\
\text { population: } \\
\mathrm{ACP}=19.5 \text { vs. } \\
\mathrm{ABCP}=19.8 \\
\text { vs. } \mathrm{BCP}=14.9\end{array}$ & $\begin{array}{c}\text { In the ITT * } \\
\text { population: } \\
\mathrm{ACP}=- \text { vs. } \\
\mathrm{ABCP}=8.4 \text { vs. } \\
\mathrm{BCP}=6.8\end{array}$ & $\begin{array}{c}\text { NCT02366143 } \\
{[40]}\end{array}$ & [41-44] \\
\hline $\begin{array}{l}\text { Small cell lung } \\
\text { cancer }\end{array}$ & $\begin{array}{l}\text { Chemotherapy and } \\
\text { immunotherapy }\end{array}$ & Irinotecan and Dinutuximab & II/III stage & 6.9 & 3.5 & $\begin{array}{c}\text { NCT03098030 } \\
{[45]}\end{array}$ & {$[46]$} \\
\hline
\end{tabular}


Table 1. Cont.

\begin{tabular}{|c|c|c|c|c|c|c|c|}
\hline Cancer & $\begin{array}{l}\text { Combination Therapy } \\
\text { Scheme }\end{array}$ & Trial Design & $\begin{array}{l}\text { Clinical } \\
\text { Stage }\end{array}$ & $\begin{array}{l}\text { Median OS * } \\
\text { (Months) }\end{array}$ & $\begin{array}{l}\text { Median PFS } \\
* \text { (Months) }\end{array}$ & $\begin{array}{l}\text { ClinicalTrial.gov } \\
\text { ID }\end{array}$ & Ref. \\
\hline Breast cancer & $\begin{array}{l}\text { Chemotherapy and } \\
\text { immunotherapy }\end{array}$ & Paclitaxel and Durvalumab & I/II stage & - & - & $\begin{array}{c}\text { NCT02628132 } \\
{[47]}\end{array}$ & - \\
\hline Breast cancer & $\begin{array}{l}\text { Chemotherapy and } \\
\text { immunotherapy }\end{array}$ & $\begin{array}{c}\text { Nab-paclitaxel and } \\
\text { Durvalumab (MEDI4736) } \\
\text { Epirubicin and } \\
\text { Cyclophosphamide and } \\
\text { Durvalumab (MEDI4736) }\end{array}$ & II stage & - & - & $\begin{array}{c}\text { NCT02685059 } \\
{[48]}\end{array}$ & [49] \\
\hline Breast cancer & $\begin{array}{c}\text { Chemotherapy and target } \\
\text { therapy }\end{array}$ & Eribulin and PQR309 & I/II stage & - & - & $\begin{array}{c}\text { NCT02723877 } \\
{[50]}\end{array}$ & [51] \\
\hline Breast cancer & $\begin{array}{l}\text { Chemotherapy and } \\
\text { immunotherapy }\end{array}$ & $\begin{array}{c}\text { Docetaxel and carboplatin and } \\
\text { trastuzumab } \\
\text { Epirubicin and } \\
\text { cyclophosphamide followed } \\
\text { by docetaxel and trastuzumab }\end{array}$ & II stage & - & - & $\begin{array}{l}\text { NCT03140553 } \\
{[52]}\end{array}$ & [53] \\
\hline Breast cancer & $\begin{array}{l}\text { Chemotherapy and } \\
\text { immunotherapy }\end{array}$ & $\begin{array}{l}\text { Cyclophosphamide and } \\
\text { Pembrolizumab }\end{array}$ & II stage & - & - & NCT03139851 & - \\
\hline Breast cancer & $\begin{array}{l}\text { Surgery and } \\
\text { immunotherapy }\end{array}$ & $\begin{array}{c}\text { Cryosurgery and NK } \\
\text { immunotherapy }\end{array}$ & I/II stage & - & - & $\begin{array}{l}\text { NCT02844335 } \\
{[55]}\end{array}$ & - \\
\hline Breast cancer & $\begin{array}{l}\text { Chemotherapy and } \\
\text { immunotherapy }\end{array}$ & $\begin{array}{c}\text { Non-pegylated liposomal } \\
\text { Doxorubicin and Trastuzumab }\end{array}$ & I stage & - & 7.2 & $\begin{array}{c}\text { NCT02562378 } \\
{[56]}\end{array}$ & {$[57,58]$} \\
\hline Breast cancer & $\begin{array}{l}\text { Chemotherapy and } \\
\text { immunotherapy }\end{array}$ & $\begin{array}{l}\text { Docetaxel and Pertuzumab } \\
\text { and Trastuzumab }\end{array}$ & IV stage & - & 23.0 & $\begin{array}{l}\text { NCT02445586 } \\
{[59]}\end{array}$ & - \\
\hline Breast cancer & $\begin{array}{l}\text { Chemotherapy and } \\
\text { immunotherapy }\end{array}$ & Eribulin and Durvalumab & I stage & - & - & $\begin{array}{c}\text { NCT03430518 } \\
{[60]}\end{array}$ & {$[61]$} \\
\hline Breast cancer & $\begin{array}{l}\text { Chemotherapy and } \\
\text { immunotherapy }\end{array}$ & $\begin{array}{l}\text { Docetaxel and Pertuzumab } \\
\text { (Perjeta) and Trastuzumab } \\
\text { (Herceptin) }\end{array}$ & III stage & - & 18.7 & $\begin{array}{c}\text { NCT02402712 } \\
{[62]}\end{array}$ & [63] \\
\hline Breast cancer & $\begin{array}{l}\text { Target therapy and } \\
\text { immunotherapy }\end{array}$ & Ibrutinib and Durvalumab & I/II stage & 4.2 & 1.7 & $\begin{array}{c}\text { NCT02403271 } \\
{[64]}\end{array}$ & {$[65]$} \\
\hline Breast cancer & $\begin{array}{l}\text { Hormone } \\
\text { therapy and } \\
\text { targeted therapy }\end{array}$ & Letrozole and Palbociclib & IV stage & - & - & $\begin{array}{c}\text { NCT02679755 } \\
{[66]}\end{array}$ & - \\
\hline $\begin{array}{l}\text { Metastatic Breast } \\
\text { Cancer }\end{array}$ & $\begin{array}{c}\text { Chemotherapy and target } \\
\text { therapy }\end{array}$ & Paclitaxel and S81694 & I/II stage & - & - & $\begin{array}{c}\text { NCT03411161 } \\
{[67]}\end{array}$ & - \\
\hline Breast cancer & $\begin{array}{l}\text { Hormone } \\
\text { therapy and } \\
\text { targeted therapy }\end{array}$ & Letrozole and Nintedanib & I stage & - & - & $\begin{array}{c}\text { NCT02619162 } \\
{[68]}\end{array}$ & [69] \\
\hline Breast cancer & $\begin{array}{l}\text { Hormone } \\
\text { therapy and } \\
\text { targeted therapy }\end{array}$ & Letrozole and Ribociclib & II stage & - & - & $\begin{array}{l}\text { NCT03248427 } \\
{[70]}\end{array}$ & [71] \\
\hline Breast Cancer & $\begin{array}{l}\text { Chemotherapy and } \\
\text { immunotherapy and } \\
\text { hormone therapy }\end{array}$ & $\begin{array}{c}\text { Epirubicin, } \\
\text { Cyclophosphamide, } \\
\text { Nivolumab, Triptorelin, } \\
\text { Exemestane }\end{array}$ & II stage & - & - & $\begin{array}{l}\text { NCT04659551 } \\
{[72]}\end{array}$ & - \\
\hline $\begin{array}{c}\text { Breast Cancer } \\
\text { Bone-dominant } \\
\text { metastatic breast } \\
\text { cancer }\end{array}$ & $\begin{array}{l}\text { Immunotherapy and } \\
\text { hormone therapy and } \\
\text { radiopharmaceutical drug }\end{array}$ & $\begin{array}{c}\text { Denosumab and } \\
\text { Tamoxifen/Fulvestrant and } \\
\text { Ra-223 dichloride }\end{array}$ & II stage & - & $\begin{array}{c}7.4 \text { or } 16 \\
\text { (bone- } \\
\text { dominant } \\
\text { metastases) }\end{array}$ & $\begin{array}{l}\text { NCT02366130 } \\
{[73]}\end{array}$ & [74] \\
\hline $\begin{array}{l}\text { Estrogen } \\
\text { receptor positive } \\
\text { breast cancer }\end{array}$ & $\begin{array}{l}\text { Hormone } \\
\text { therapy and } \\
\text { targeted therapy }\end{array}$ & Tamoxifen and TAK-228 & II stage & - & - & $\begin{array}{l}\text { NCT02988986 } \\
{[75]}\end{array}$ & {$[76,77]$} \\
\hline Breast cancer & $\begin{array}{l}\text { Chemotherapy and } \\
\text { immunotherapy }\end{array}$ & $\begin{array}{l}\text { Docetaxel and Pertuzumab } \\
\text { and Trastuzumab }\end{array}$ & III stage & NA & 14.5 & $\begin{array}{l}\text { NCT02896855 } \\
{[78]}\end{array}$ & [79] \\
\hline Prostate cancer & $\begin{array}{c}\text { Hormone } \\
\text { therapy and } \\
\text { immunotherapy }\end{array}$ & $\begin{array}{l}\text { Abiraterone and TRC105 } \\
\text { Enzalutamide and TRC105 }\end{array}$ & II stage & - & - & $\begin{array}{l}\text { NCT03418324 } \\
{[80]}\end{array}$ & \\
\hline Prostate cancer & $\begin{array}{c}\text { Immunotherapy and } \\
\text { surgery }\end{array}$ & $\begin{array}{l}\text { huJ591 and } 89 \mathrm{Zr}-\mathrm{J} 591 \text { and } \\
\text { radical prostatectomy }\end{array}$ & I stage & - & - & $\begin{array}{c}\text { NCT02693860 } \\
{[81]}\end{array}$ & - \\
\hline $\begin{array}{l}\text { Castration } \\
\text { resistant prostate } \\
\text { cancer }\end{array}$ & $\begin{array}{l}\text { Chemotherapy and } \\
\text { cryoimmunotherapy and } \\
\text { immunotherapy }\end{array}$ & $\begin{array}{l}\text { Cyclophosphamide and } \\
\text { Dendritic cell-based } \\
\text { cryoimmunotherapy and } \\
\text { Ipilimumab }\end{array}$ & I stage & - & 5 (150 days) & $\begin{array}{c}\text { NCT02423928 } \\
{[82]}\end{array}$ & [83] \\
\hline Prostate cancer & $\begin{array}{c}\text { Hormone } \\
\text { therapy and } \\
\text { targeted therapy }\end{array}$ & Enzalutamide and LY3023414 & II stage & - & 7.5 & $\begin{array}{c}\text { NCT02407054 } \\
{[84]}\end{array}$ & [85] \\
\hline $\begin{array}{l}\text { Castrate- } \\
\text { resistant prostate } \\
\text { cancer }\end{array}$ & $\begin{array}{l}\text { Immunotherapy and } \\
\text { radiopharmaceutical drug }\end{array}$ & $\begin{array}{c}\text { Atezolizumab and Radium-223 } \\
\text { Dichloride }\end{array}$ & I stage & 16.3 & 3.0 & $\begin{array}{c}\text { NCT02814669 } \\
{[86]}\end{array}$ & [87] \\
\hline Prostate cancer & $\begin{array}{l}\text { Hormone } \\
\text { therapy and surgery }\end{array}$ & $\begin{array}{l}\text { Apalutamide and Radical } \\
\text { Prostatectomy }\end{array}$ & II stage & - & - & $\begin{array}{c}\text { NCT03124433 } \\
{[88]}\end{array}$ & - \\
\hline Prostate cancer & $\begin{array}{l}\text { Hormone } \\
\text { therapy and } \\
\text { target therapy }\end{array}$ & $\begin{array}{c}\text { Prednisone and } \\
\text { Apalutamide/Abiraterone } \\
\text { Acetate and Niraparib }\end{array}$ & I stage & - & - & $\begin{array}{l}\text { NCT02924766 } \\
{[89]}\end{array}$ & {$[90,91]$} \\
\hline $\begin{array}{c}\text { Prostate } \\
\text { carcinoma } \\
\text { metastatic to the } \\
\text { bone }\end{array}$ & $\begin{array}{c}\text { Hormone } \\
\text { therapy and } \\
\text { radiopharmaceutical drug }\end{array}$ & $\begin{array}{c}\text { Enzalutamide and Radium-223 } \\
\text { Dichloride }\end{array}$ & II stage & - & - & $\begin{array}{l}\text { NCT02507570 } \\
{[92]}\end{array}$ & [93] \\
\hline
\end{tabular}


Table 1. Cont.

\begin{tabular}{|c|c|c|c|c|c|c|c|}
\hline Cancer & $\begin{array}{l}\text { Combination Therapy } \\
\text { Scheme }\end{array}$ & Trial Design & $\begin{array}{l}\text { Clinical } \\
\text { Stage }\end{array}$ & $\begin{array}{l}\text { Median OS * } \\
\text { (Months) }\end{array}$ & $\begin{array}{l}\text { Median PFS } \\
{ }^{*} \text { (Months) }\end{array}$ & $\begin{array}{c}\text { ClinicalTrial.gov } \\
\text { ID }\end{array}$ & Ref. \\
\hline Prostate cancer & $\begin{array}{l}\text { Hormone } \\
\text { therapy and } \\
\text { target therapy and } \\
\text { radiotherapy }\end{array}$ & $\begin{array}{l}\text { Leuprolide acetate/Goserelin } \\
\text { acetate/Degarelix, PLX3397, } \\
\text { Radiation Therapy }\end{array}$ & I stage & - & - & $\underset{[94]}{\mathrm{NCT} 02472275}$ & - \\
\hline Colon cancer & $\begin{array}{l}\text { Chemotherapy and } \\
\text { immunotherapy }\end{array}$ & $\begin{array}{l}\text { TAS-102 (Trifluridine/tipiracil) } \\
\text { and Panitumumab }\end{array}$ & I/II stage & - & 5.8 & $\begin{array}{c}\text { NCT02613221 } \\
{[95]}\end{array}$ & {$[96,97]$} \\
\hline Colorectal cancer & $\begin{array}{c}\text { Chemotherapy and } \\
\text { target } \\
\text { therapy }\end{array}$ & $\begin{array}{c}\text { Hydroxychloroquine, } \\
\text { Entinostat, Regorafenib }\end{array}$ & I/II stage & - & - & $\underset{[98]}{\text { NCT03215264 }}$ & - \\
\hline $\begin{array}{l}\text { Solid tumor } \\
\text { Colorectal cancer }\end{array}$ & $\begin{array}{c}\text { Immunotherapy and } \\
\text { target } \\
\text { therapy }\end{array}$ & Magrolimab and Cetuximab & I/II stage & $\begin{array}{l}9.5 \\
7.6\end{array}$ & $\begin{array}{l}3.6 \\
1.9\end{array}$ & $\begin{array}{l}\text { NCT02953782 } \\
{[99]}\end{array}$ & [100] \\
\hline $\begin{array}{l}\text { Metastatic } \\
\text { colorectal cancer }\end{array}$ & $\begin{array}{c}\text { Chemotherapy and } \\
\text { target } \\
\text { therapy }\end{array}$ & FOLFIRI and Aflibercept & II stage & 12.6 & 7.4 & $\begin{array}{l}\text { NCT02970916 } \\
{[101]}\end{array}$ & - \\
\hline $\begin{array}{l}\text { Metastatic } \\
\text { colorectal cancer }\end{array}$ & $\begin{array}{c}\text { Chemotherapy and } \\
\text { target } \\
\text { therapy }\end{array}$ & Pemetrexed and Erlotinib & II stage & 7.3 & 2.5 & $\begin{array}{c}\text { NCT02723578 } \\
{[102]}\end{array}$ & [103] \\
\hline $\begin{array}{c}\text { Metastatic } \\
\text { colorectal cancer }\end{array}$ & $\begin{array}{c}\text { Immunotherapy and } \\
\text { target } \\
\text { therapy }\end{array}$ & $\begin{array}{l}\text { Spartalizumab and } \\
\text { Regorafenib }\end{array}$ & I stage & - & - & $\begin{array}{l}\text { NCT03081494 } \\
{[104]}\end{array}$ & - \\
\hline $\begin{array}{c}\text { Metastatic } \\
\text { colorectal cancer }\end{array}$ & $\begin{array}{l}\text { Chemotherapy and } \\
\text { immunotherapy }\end{array}$ & $\begin{array}{l}\text { TAS-102 (Trifluridine/tipiracil) } \\
\text { and Bevacizumab } \\
\text { Capecitabine and Bevacizumab }\end{array}$ & II stage & $\begin{array}{l}18.0 \\
16.2\end{array}$ & $\begin{array}{l}9.2 \\
7.8\end{array}$ & $\begin{array}{l}\text { NCT02743221 } \\
{[105]}\end{array}$ & [106] \\
\hline $\begin{array}{l}\text { Microsatellite } \\
\text { stable relapsed } \\
\text { or refractory } \\
\text { colorectal cancer }\end{array}$ & $\begin{array}{c}\text { Immunotherapy and } \\
\text { target } \\
\text { therapy }\end{array}$ & $\begin{array}{l}\text { Avelumab and Tomivosertib } \\
\text { (eFT508) }\end{array}$ & II stage & - & - & $\begin{array}{l}\text { NCT03258398 } \\
{[107]}\end{array}$ & [108] \\
\hline $\begin{array}{l}\text { Colorectal } \\
\text { neoplasms }\end{array}$ & $\begin{array}{l}\text { Chemotherapy and } \\
\text { immunotherapy }\end{array}$ & mFOLFOX6 and BI 695502 & III stage & 19.4 & 10.5 & $\begin{array}{c}\text { NCT02776683 } \\
{[109]}\end{array}$ & - \\
\hline $\begin{array}{l}\text { Colorectal } \\
\text { neoplasm }\end{array}$ & $\begin{array}{c}\text { Chemotherapy and } \\
\text { target } \\
\text { therapy }\end{array}$ & mFOLFOX6 and Selinexor & I stage & - & - & $\begin{array}{l}\text { NCT02384850 } \\
{[110]}\end{array}$ & [111] \\
\hline $\begin{array}{c}\text { Refractory } \\
\text { metastatic } \\
\text { colorectal cancer }\end{array}$ & $\begin{array}{l}\text { Chemotherapy and } \\
\text { immunotherapy }\end{array}$ & $\begin{array}{l}\text { TAS-102 (Trifluridine/tipiracil) } \\
\text { and Nivolumab }\end{array}$ & II stage & - & 2.2 & $\begin{array}{l}\text { NCT02860546 } \\
{[112]}\end{array}$ & {$[113,114]$} \\
\hline Colorectal cancer & $\begin{array}{c}\text { Immunotherapy and } \\
\text { target } \\
\text { therapy }\end{array}$ & Durvalumab and Pexidartinib & I stage & - & - & $\begin{array}{l}\text { NCT02777710 } \\
{[115]}\end{array}$ & - \\
\hline Colorectal cancer & $\begin{array}{c}\text { Immunotherapy and } \\
\text { target } \\
\text { therapy }\end{array}$ & $\begin{array}{l}\text { Atezolizumab and } \\
\text { Cobimetinib }\end{array}$ & III stage & 8.87 & 1.91 & $\begin{array}{c}\text { NCT02788279 } \\
{[116]}\end{array}$ & [117] \\
\hline Colorectal cancer & $\begin{array}{c}\text { Immunotherapy and } \\
\text { target } \\
\text { therapy }\end{array}$ & $\begin{array}{c}\text { Atezolizumab and } \\
\text { Bevacizumab and Cobimetinib }\end{array}$ & I stage & & & $\begin{array}{c}\text { NCT02876224 } \\
{[118]}\end{array}$ & - \\
\hline $\begin{array}{l}\text { Colorectal } \\
\text { neoplasms }\end{array}$ & $\begin{array}{c}\text { Chemotherapy and } \\
\text { target } \\
\text { therapy }\end{array}$ & FOLFIRI and Cetuximab & III stage & - & 11.4 & $\begin{array}{c}\text { NCT02484833 } \\
{[119]}\end{array}$ & {$[120,121]$} \\
\hline $\begin{array}{l}\text { Metastatic } \\
\text { colorectal cancer }\end{array}$ & $\begin{array}{l}\text { Chemotherapy and } \\
\text { immunotherapy }\end{array}$ & Irinotecan and AZD1775 & I stage & - & - & $\begin{array}{c}\text { NCT02906059 } \\
{[122]}\end{array}$ & [123] \\
\hline $\begin{array}{c}\text { Metastatic } \\
\text { colorectal cancer }\end{array}$ & $\begin{array}{c}\text { Chemotherapy and } \\
\text { target } \\
\text { therapy }\end{array}$ & $\begin{array}{l}\text { TAS-102 (Trifluridine/tipiracil) } \\
\text { and Brontictuzumab }\end{array}$ & I stage & - & - & $\underset{[124]}{\text { NCT03031691 }}$ & - \\
\hline $\begin{array}{l}\text { Metastatic } \\
\text { colorectal cancer }\end{array}$ & $\begin{array}{c}\text { Chemotherapy and } \\
\text { target } \\
\text { therapy }\end{array}$ & FOLFIRI and OMP-131R10 & I stage & - & - & $\begin{array}{l}\text { NCT02482441 } \\
{[125]}\end{array}$ & - \\
\hline Colorectal cancer & $\begin{array}{c}\text { Immunotherapy and } \\
\text { target } \\
\text { therapy }\end{array}$ & Pembrolizumab and AMG820 & I/II stage & 38.963 & 5.396 & $\begin{array}{l}\text { NCT02713529 } \\
{[126]}\end{array}$ & [127] \\
\hline $\begin{array}{c}\text { Pancreatic } \\
\text { adenocarcinoma } \\
(\text { PDAC) }\end{array}$ & $\begin{array}{l}\text { Local ablative therapy } \\
\text { and } \\
\text { immunotherapy }\end{array}$ & $\begin{array}{l}\text { Irreversible electroporation } \\
\text { (IRE) and allogeneic } \gamma \delta \mathrm{T} \text { cells }\end{array}$ & I/II stage & 14.5 & 11 & $\begin{array}{l}\text { NCT03180437 } \\
{[128]}\end{array}$ & [129] \\
\hline $\begin{array}{l}\text { Pancreatic } \\
\text { neoplasms }\end{array}$ & $\begin{array}{c}\text { Local ablative therapy } \\
\text { and } \\
\text { immunotherapy }\end{array}$ & $\begin{array}{l}\text { Irreversible electroporation } \\
\text { (IRE) and NK cells }\end{array}$ & I/II stage & - & - & $\begin{array}{c}\text { NCT02718859 } \\
{[130]}\end{array}$ & - \\
\hline $\begin{array}{c}\text { Metastatic } \\
\text { pancreatic cancer }\end{array}$ & $\begin{array}{l}\text { Target therapy and } \\
\text { Chemotherapy }\end{array}$ & $\begin{array}{c}\mathrm{RX}-3117 \\
\text { (Fluorocyclopentenylcytosine) } \\
\text { and Abraxane }\end{array}$ & I/II stage & - & - & $\begin{array}{l}\text { NCT03189914 } \\
{[131]}\end{array}$ & [132] \\
\hline $\begin{array}{c}\text { Advanced/ } \\
\text { metastasized } \\
\text { pancreatic cancer }\end{array}$ & $\begin{array}{c}\text { Chemotherapy and } \\
\text { target } \\
\text { therapy }\end{array}$ & $\begin{array}{l}\text { Gemcitabine, nab-paclitaxel, } \\
\text { LED225 (Sonidegib) }\end{array}$ & I/II stage & 6.0 & - & $\begin{array}{l}\text { NCT02358161 } \\
\quad[133]\end{array}$ & [134] \\
\hline Pancreatic cancer & $\begin{array}{c}\text { Chemotherapy and } \\
\text { target } \\
\text { therapy }\end{array}$ & $\begin{array}{l}\text { Gemcitabine and BP31510 } \\
\text { (Ubidecarenone, USP) }\end{array}$ & I stage & - & - & $\begin{array}{l}\text { NCT02650804 } \\
{[135]}\end{array}$ & [136] \\
\hline Pancreatic cancer & $\begin{array}{c}\text { Immunotherapy and } \\
\text { target } \\
\text { therapy }\end{array}$ & $\begin{array}{l}\text { Pembrolizumab and Olaptesed } \\
\text { pegol }\end{array}$ & I/II stage & - & 1.87 & $\begin{array}{l}\text { NCT03168139 } \\
\quad[137]\end{array}$ & {$[138,139]$} \\
\hline
\end{tabular}


Table 1. Cont.

\begin{tabular}{|c|c|c|c|c|c|c|c|}
\hline Cancer & $\begin{array}{l}\text { Combination Therapy } \\
\text { Scheme }\end{array}$ & Trial Design & $\begin{array}{l}\text { Clinical } \\
\text { Stage }\end{array}$ & $\begin{array}{l}\text { Median OS * } \\
\text { (Months) }\end{array}$ & $\begin{array}{l}\text { Median PFS } \\
* \text { (Months) }\end{array}$ & $\begin{array}{l}\text { ClinicalTrial.gov } \\
\text { ID }\end{array}$ & Ref. \\
\hline Pancreatic cancer & $\begin{array}{l}\text { Immunotherapy and } \\
\text { radiotherapy }\end{array}$ & $\begin{array}{c}\text { Nivolumab and Cabiralizumab } \\
\text { and Stereotactic Body } \\
\text { Radiotherapy (SBRT) }\end{array}$ & II stage & - & - & $\begin{array}{c}\text { NCT03599362 } \\
{[140]}\end{array}$ & [141] \\
\hline Pancreatic cancer & $\begin{array}{l}\text { Chemotherapy and } \\
\text { irreversible } \\
\text { electroporation }\end{array}$ & $\begin{array}{l}\text { Gemcitabine and Irreversible } \\
\text { electroporation (IRE) }\end{array}$ & I stage & - & - & $\begin{array}{l}\text { NCT02981719 } \\
{[142]}\end{array}$ & - \\
\hline Pancreatic cancer & $\begin{array}{l}\text { Chemotherapy and } \\
\text { immunotherapy }\end{array}$ & FOLFOX and Pegilodecakin & III stage & 5.8 & 2.1 & $\begin{array}{c}\text { NCT02923921 } \\
{[143]}\end{array}$ & [144] \\
\hline Pancreatic cancer & $\begin{array}{l}\text { Chemotherapy and } \\
\text { immunotherapy }\end{array}$ & $\begin{array}{l}\text { nab-Paclitaxel, Gemcitabine, } \\
\text { ALT-803 }\end{array}$ & I/II stage & - & - & $\begin{array}{c}\text { NCT02559674 } \\
\text { [145] }\end{array}$ & [146] \\
\hline $\begin{array}{c}\text { Metastatic } \\
\text { pancreatic cancer }\end{array}$ & $\begin{array}{c}\text { Immunotherapy and } \\
\text { target } \\
\text { therapy }\end{array}$ & $\begin{array}{l}\text { Pembrolizumab and } \\
\text { Acalabrutinib }\end{array}$ & II stage & - & 1.4 & $\begin{array}{c}\text { NCT02362048 } \\
\text { [147] }\end{array}$ & [148] \\
\hline $\begin{array}{c}\text { Metastatic } \\
\text { pancreatic cancer }\end{array}$ & $\begin{array}{c}\text { Immunotherapy and } \\
\text { target } \\
\text { therapy }\end{array}$ & Durvalumab and Galunisertib & I stage & 5.72 & 1.87 & $\begin{array}{l}\text { NCT02734160 } \\
\text { [149] }\end{array}$ & {$[150,151]$} \\
\hline Pancreatic cancer & $\begin{array}{l}\text { Chemotherapy and } \\
\text { immunotherapy }\end{array}$ & $\begin{array}{l}\text { nab-Paclitaxel, Gemcitabine, } \\
\text { Selicrelumab }\end{array}$ & I stage & - & - & $\begin{array}{c}\text { NCT02588443 } \\
\text { [152] }\end{array}$ & - \\
\hline Pancreatic cancer & $\begin{array}{l}\text { Chemotherapy and } \\
\text { radiotherapy }\end{array}$ & $\begin{array}{c}\text { mFOLFIRINOX and } \\
\text { Stereotactic Body } \\
\text { Radiotherapy (SBRT) }\end{array}$ & II stage & - & - & $\begin{array}{c}\text { NCT03891472 } \\
{[153]}\end{array}$ & - \\
\hline Pancreatic cancer & $\begin{array}{l}\text { Chemotherapy and } \\
\text { immunotherapy }\end{array}$ & Gemcitabine and M7824 & I/II stage & - & - & $\begin{array}{c}\text { NCT03451773 } \\
\text { [154] }\end{array}$ & - \\
\hline $\begin{array}{l}\text { Pancreatic } \\
\text { neoplasms }\end{array}$ & $\begin{array}{c}\text { Chemotherapy and } \\
\text { target } \\
\text { therapy }\end{array}$ & $\begin{array}{l}\text { nab-Paclitaxel, Gemcitabine, } \\
\text { Napabucasin }\end{array}$ & III stage & - & - & $\begin{array}{l}\text { NCT02993731 } \\
\text { [155] }\end{array}$ & {$[156,157]$} \\
\hline
\end{tabular}

Table 1 completed, interventional clinical trials combined anticancer therapies; study started in the years 2015-2020 (ClinicalTrials.gov last assessed on 26 April 2021). Information was retrieved from ClinicalTrials.gov, by searching for 'condition or disease: 'lung cancer'; 'breast cancer'; ' prostate cancer'; 'colorectal cancer'; 'pancreatic cancer', status recruitment: 'completed', study type: 'interventional studies (Clinical Trials)'. Study start: from 1 January 2015 to 31 December 2020. * OS—overall survival, * PFS—progression-free survival, NE—not estimable, ${ }^{*}$ ITT-intention-to-treat.

\section{General Information about Photodynamic Therapy and Hyperthermia}

\subsection{PDT}

In this article we focus on PDT and hyperthermia treatment as a very interesting example of a combination strategy. That is why this section includes basic information about the selected therapies and their modes of action. Photodynamic therapy (PDT) requires three independent factors: photosensitizer (PS), light at proper wavelength to excite PS, and oxygen. We should note that although a photosensibilized reaction can be possible without any oxygen, a photodynamic reaction involves oxygen by definition. The main advantage of PDT as a cancer treatment is based on its double selectivity: PS is a drug that accumulates better in neoplasm tissues, and light can activate only the PS that is localized in an illuminated area. Ideally, PS and light separately are harmless, and in the presence of oxygen, both of them together can create a deadly weapon-reactive oxygen species (ROS). Photosensitizer can be understand as a pro-drug that requires light to become a drug. When we talk about PDT in the context of cancer treatment, the ideal photosensitizer should accumulate selectively only in cancerous tissue, it should have a minimal toxicity before the light exposure and a high toxicity after using light in a given range of wavelengths. At the same time, it must not cause any phototoxic effects on healthy cells. The photosensitizer should absorb light in the range of about 600 to $1200 \mathrm{~nm}$ to perform effectively, in the context of light penetration into the tissues (lower light wavelengths are absorbed by endogenous dyes, longer wavelengths are selectively absorbed by water). There are several subgenerations of photosensitizers [158-161] categorized by their chemical structures. One representative of the first generation photosensitizer is hematoporphyrin. Porphyrins and porphyrin derivatives are examples of second-generation photosensitizers. Moreover, 5-aminolevulinic acid (ALA), which is used to treat skin cancers, is used quite often in PDT. These compounds consist of four pyrrole molecules that are linked together via methylene bridges. Another example of porphyrin derivatives are chlorines. They are chemical compounds that have modified the double bond in their structure and could absorb light in the infrared spectrum more strongly. Due to the fact that chlorines can be excited by infrared light, they are able to penetrate tissue with light more deeply. These 
chemical compounds are removed quite quickly from a human body-they need about $24-48 \mathrm{~h}$ to be cleared, which indicates less toxicity. Bacteriochlorin ale phthalocyanines are also extremely promising photosensitizers in anti-cancer therapies [162]. The can by excited with red/infrared light; pre-clinical and clinical trials show very promising results. Good examples include TOOKAD against prostate cancer [163-166] and LUZ11 against head and neck cancers [167], photosensitizers with advanced clinical trials. Light is an inseparable element of a photodynamic therapy. The theory that solar radiation can be used to treat many diseases is very old $[168,169]$. It was argued that solar radiation could cure diseases, such as albinism and psoriasis. In 1903, Niels Finsen received the Nobel Prize for his work on phototherapy. He used UV radiation to treat skin tuberculosis. Later, photodynamic therapy was used to treat skin cancer. The wavelength should be adjusted to the photosensitizer's absorption spectrum. Different light sources can be used in PDT, e.g., diode, xenon or halogen lasers [170]. It is worth noting that the longer the wavelength, the deeper its beam penetrates into the tissue. Therefore, for about $700 \mathrm{~nm}$, the depth of light penetration is about $1.5 \mathrm{~cm}$ (the light power density decreases in relation to the square of the distance).

The last (but not least) necessary element of PDT is oxygen, specifically molecular oxygen, which is dissolved in the tissues. The presence of oxygen allows the formation of reactive oxygen species, such as singlet oxygen, hydroxyl radical, or superoxide anion radical. The effectiveness of therapy is considered a cytotoxic effect under the influence of oxidation. The combination of these three elements is fundamental when it comes to the principle of PDT. Separately, these three factors are believed to be safe, but their combination has an effect on the cells, it contributes to their destruction, making photodynamic therapy effective, and it is increasingly used to treat various diseases. There are two main mechanisms for the formation of free radicals and reactive oxygen species in PDT.

The type I mechanism occurs when the oxygen concentration is low and free radical forms are present. This mechanism involves the transfer of an electron or hydrogen atom between the excited photosensitizer and the irradiated tumor tissue. As a result of the photochemical reaction, radicals or anion radicals are being formed. The type II mechanism occurs when the oxygen concentration is close to the physiological concentration. There is a transfer of energy between the photosensitizer, which is in the triplet state, and between the excited form-singlet oxygen.

To sum up the basic information about photodynamic therapy, the method is an alternative way of treating cancer. Among the advantages there are: lower toxicity, high selectivity of the method, and reduction of side effects as compared to chemotherapy or surgery. However, this method also has some disadvantages. Unfortunately, the dependence on an external light source makes PDT mainly suitable for the treatment of tumors on or just under the skin, and on the lining of internal organs [171].

In addition, intravenous administration of PDT may cause systemic toxicity, and due to abnormal angiogenesis, non-specific interaction with blood components and the presence of fibroblasts in cancer foci, only a part of PDT sensitizing substances can be used successfully in this therapy [171-173]. Unfortunately, oxygen consumption within the tumor may exacerbate tumor hypoxia, leading to PDT treatment failure [174-176]. This method is also quite expensive. The cost of specialized equipment is particularly high. In addition, the selection of an appropriate photosensitizer is very hard. It must not be toxic to the patient and it should give the least possible side effects. It is also worth mentioning that PDT may cause temporary hypersensitivity to sunlight.

\subsection{Hyperthermia}

Hyperthermia is a state in which temperature is elevated above the physiological norm. The hyperthermia therapy involves a controlled increase in body tissue locally or selectively to the needed area. Many techniques can be used to achieve it and each has its own pros and cons. For example, contact heating can be the easiest way to heat superficial tissue; however, it will generate significant temperature gradient, which can be responsible 
for uneven biological effects. On the other hand, different types of the waves can be used, e.g., ultrasound, radio frequency, or infrared-each is effective based on different tissue parameters (considered pros or cons based on the effects needed). Requirements of a high precision device and advanced dosimeters and treatment planning are for this group of heating techniques. Another hyperthermia induction in the tissue involves a combination of nanomaterials, which can accumulate inside the tissue of choice and be the source of heat, after the activation, e.g., gold nanorods could be activated by the near-infrared light. However, this latter way of heating could be the most precise, but also the hardest to perform because of a wide range of influential factors. It is widely known that elevated temperature informs us about inflammation and diseases, and it is one of the immune system defense mechanisms. The normal human body temperature ranges from $36.2^{\circ} \mathrm{C}$ to $37.5^{\circ} \mathrm{C}$ [177]. The Table 2 shows the temperature range for specific parts of the human body. Human normothermia is reported to be $36.8^{\circ} \mathrm{C}$ [178].

Table 2. Temperature ranges for specific parts of the human body.

\begin{tabular}{cc}
\hline Temperature Range $\left({ }^{\circ} \mathbf{C}\right)$ & Selected Area in the Human Body \\
\hline $36.32-37.76$ & rectal \\
$35.76-37.52$ & tympanic \\
$35.61-37.61$ & urine \\
$35.73-37.41$ & oral \\
$35.01-36.93$ & axillary \\
\hline
\end{tabular}

Generally, we can distinguish between general, systemic hyperthermia, and local sitespecific hyperthermia. Furthermore, in both types, hyperthermia can be generated by the organism itself (e.g., fewer, inflammation) or can be induced artificially (e.g., irradiation). From the biological perspective, one more classification is essential that is based on the established tissue temperature. Hyperthermia is defined as a temperature ranging from $39^{\circ} \mathrm{C}$ and above, where the selective effect of heat on tumors, cancer tissues, promotes killing cancer cells by the influence of high temperature [179].

The temperature range from $40{ }^{\circ} \mathrm{C}$ to $43^{\circ} \mathrm{C}$ is most commonly used in the context of hyperthermia in the treatment of cancer $[180,181]$. Mild hyperthermia is an increase in temperature in the range from $41^{\circ} \mathrm{C}$ to $43^{\circ} \mathrm{C}$ [182]. Hyperthermia has been used to treat cancer from ancient times [183]. A lot of research has shown that artificial temperature raising can damage cancer cells. Hyperthermia affects the angiogenesis process and can also damage the structure and reduce the tumor size $[16,184]$. In this aspect, it is a method of a targeted therapy. However, hyperthermia is used in combination with other methods in order to increase their effectiveness, e.g., by improving drug accumulation [185-187]. Very often, hyperthermia is combined with chemotherapy or radiation therapy [188].

The main goal of hyperthermia is to sensitize cancer cells to the subsequent treatment method, so it can be understand as a physical adjuvant treatment. It is believed that more sensitive cells should be less resistant to X-rays and chemotherapeutics. For example, cells treated with high temperature may inhibit the repair of drug-induced DNA damage by denaturing the proteins involved in this repair [189]. As mentioned above, hyperthermia can be divided by its location. Local hyperthermia can be carried out using external or internal energy sources, regional hyperthermia through organ perfusion; there is also a whole body hyperthermia [190]. If we consider the principle of local hyperthermia, we locate the tumor area and only heat the area where the tumor is located. To provide the right amount of heat, one may use infrared, ultrasound, or microwave wavelength laser. It is possible to both heat the outside of the skin and introduce appropriate probes with a light source that will generate heat inside the body. In the context of hyperthermia, controlling tissue heating is crucial. To have control over all elements of this therapy, we need to correctly locate a selected heating area, put the heating source in the right place, and constantly monitor the temperature rise. An additional important factor for efficient hyperthermia treatment is the time of the established tissue temperature (plateau) 
and the time needed to achieve it (ramp). Based on that, the total energy deposition can be calculated. The dose of heat should be safe and should bring the expected results without, e.g., painful burns. It should be highlighted that this method can have various side effects. The most common side effects are burns, swelling, and bleeding. Therefore, hyperthermia needs to be applied carefully and should act very selectively, and the heating area should be estimated very well. It should be mentioned that different kinds of tissue will heat in a different way. Fat will heat and accumulate the temperature differently than a well perfused muscle. In this context, tumors are very special objects to heat because lack of tissue homeostasis results in pathological mechanisms of tissue cooling, e.g., uncontrolled perfusion that slows down heat dispersion, specific vessel structures that affect the possibilities of vein and artery heat enlargement. Hyperthermia may prove to be a successful adjunctive therapy for drug transport in which nanoparticles are used. An example of nanoparticles that can aid drug transport is fullerene, which can target the delivery of drugs to the tumor area [191].

Although hyperthermia is usually used as a supportive method, it can contribute to cell death directly by causing damage to the protein-lipid cell membrane as well as cause denaturation of intracellular proteins [180]. Hyperthermia also leads to dismantling, denaturation, and reorganization of cytoskeleton proteins [192]. As mentioned, hyperthermia can also lead to degradation of proteins responsible for repairing DNA damage caused by chemotherapeutics and, thus, inhibit the repair of DNA double-strand breaks in the process of homologous recombination [193,194]. High-temperature cell death can occur through both apoptosis and necrosis. The putative biological-molecular mechanism of hyperthermia is based, among others, on the expression of heat shock proteins (HSPs), induction and regulation of apoptosis, and signal transduction and modulation of drug resistance in cells. Hyperthermia can lead to cell death directly. Induction of cell death may be dependent on the p53 suppressor protein. It is also believed that apoptosis is mainly caused by activation of procaspase 2, which entails the entire cascade of Bax- or Bak-type proteins [181].

Hyperthermia also affects the immune system. In the case of local tumor hyperthermia, an influx of NK cells and macrophages to the tumor location can be observed where local heating is applied. Moreover, it is said that hyperthermia activates the immune system and generates an immune response. HT helps to increase the level of TNF-alpha. A fairly quick response from the immune system with the secretion of cytokines, such as TNF-alpha and IL-1-beta, contributes to the activation of the immune system defense mechanisms [195]. Hyperthermia is currently being modified to achieve the best results with better safety. It is proposed to use nanogold to monitor the course of hyperthermia. In addition, this technique is being optimized to heat the tumor location more efficiently, and to obtain a correspondingly long therapeutic window to introduce the drug into the tumor area more effectively, or irradiate the tumor area with X-rays. In general, nanogold particles are supposed to absorb infrared light to heat the area in which the nanogold has been located [196]. To achieve better therapeutic results, hyperthermia is being modified and new possibilities of treatment are being created.

\section{Why Are Hyperthermia and PDT Used in Treatment? Why Are They a Good Option for Combination Treatment?}

Hyperthermia and photodynamic therapy are both used in treatment since, when performed well, they provide relatively small side effects as compared to chemotherapy or radiotherapy. Undoubtedly, the dose administered is critical here, however, PDT and hyperthermia compared to other conventional methods are less toxic, less harmful, and more secure [197]. The reasons why PDT and hyperthermia should be considered as a good option for combination treatment are the following:

\subsection{Selectivity}

When it comes to the selectivity of these therapeutic methods, the photosensitizer in PDT and nanoparticles used for hyperthermia, e.g., gold nanorods, are of significant 
importance. These compounds locate more intensively in tumors than in the surrounding tissues. The light needed for PDT and hyperthermia can be used in selected regions, and the production of heat or reactive oxygen species will be intense in the target region where the appropriate wavelength of light is applied. Sensitivity to these factors may depend on the oxygen concentration in the environment, $\mathrm{pH}$, or the structure of the photosensitizer and other nanoparticles. The photosensitizer accumulates at a specific location of the lesion, and then it is activated by an appropriate wavelength of light and, thus, an excited form is performed. The resulting energy can be used to create reactive oxygen species and then a photodynamic reaction (ROS cascade) takes place.

Very often, in the context of PDT results, the concept of ablation of lesions only within a pathological tissue, which is also a result of the selective operation of this method, is taken into consideration. In addition, it also depends on the specific photosensitizer that will be used during photodynamic therapy, and how selectively it will be excited using the selected light source.

Nanoparticles needed to induce some form of hyperthermia also have the ability of selective accumulation in the cancerous tissues.

\subsection{Precision}

The light source used in these therapies plays an important role in achieving the precision of PDT and hyperthermia. Lasers with high beam collimation can be used for hyperthermia and PDT, and they can illuminate cancerous lesions very precisely. Red light is being used most often, and it can deeply penetrate the tissue. However, precision fiber optics application is opening new possibilities for blue and green light therapies (with minimalized invasiveness). This allows using PDT and hyperthermia to treat both surface lesions and tumors inside the body. According to various studies, good therapeutic effects can also be obtained by using light with a much shorter wavelength. Especially in the context of treating surface changes, blue light with a wavelength of about $400 \mathrm{~nm}$ allows penetration of up to $1 \mathrm{~mm}$, which is quite a sufficient effect. As a result, we work on the skin optimally and do not penetrate deeper skin layers. The process of optimizing PDT and hyperthermia is also important for the precision of the entire treatment. Adjusting the light source, light length, and power, depending on the patient's needs is extremely important. In terms of combining hyperthermia and photodynamic therapy, it is important to choose the appropriate temperature range in which we heat the tissue locally. An exemplary mechanism is the combination of PDT and hyperthermia using porphyrins, which are an interesting choice as photosensitizers [198]. They are used to treat bladder cancer, and they can effectively produce mitochondrial ROS [199].

The photosensitizers used are toxic when excited by light; therefore, patients are sometimes recommended not to expose to light, e.g., for one day for ALA. They may be slightly photosensitizing even without the use of light [200]. The ideal option in PDT are nano-photosensitizers that can precisely reach selected places [201]. In general, PS is safe and non-toxic when not exposed to light. The use of optical fibers and probes that are important in PDT is also of a great significance. They allow access to areas that are hard to reach, e.g., inside the body. This strategy is very successful for the treatment of prostate cancer [202]. It should be mentioned that a well-performed PDT allows reducing tumors without undue damage to properly functioning tissues. A significant increase in tumor response was also observed. It was found that the anti-tumor effect depends on the type and dose of the heat applied, type and dose of the light with a specific wavelength used, as well as the photosensitizer (e.g., mechanism of the photodynamic reaction, cellular localization, biodistribution, and pharmacokinetics), and the sequence of action (time gap between hyperthermia and PDT, time duration between PS administration, and illumination). When it comes to optimizing photodynamic therapy, the dose of the photosensitizer and laser power are crucial.

The phenomenon of hyperthermia allows the cells to be sensitized in a very precise way in order to minimize any possible side effects. Hyperthermia involves providing a 
proper portion of energy that will heat the local tissues or the tumor. The temperature is usually increased during therapy, from $40^{\circ} \mathrm{C}$ to about a maximum of $45^{\circ} \mathrm{C}$, which allows safe heating with little risk of damage to healthy, properly functioning, non-pathogenic tissues [203]. What distinguishes healthy tissues from cancer cells is the fact that healthy tissues are excellent at temperature regulation and adequate heat exchange. By contrast, cancer cells and tissues within the tumor are not able to efficiently dissipate heat due to poor blood supply; therefore, the heat is retained and accumulated, which damages the structure. According to research, cells in the S phase, i.e., in the replication process, are more susceptible to hyperthermia [204,205]. In the context of the hyperthermia mechanism, this method can be divided into external and internal. In the treatment of tumors on the skin, applicators that generate heat within the lesion are used, and thanks to this, the heat is directed into the cancerous area, and the temperature is increased only within the applicator. However, when it comes to the internal heating of, for example, tumors located within important organs, probes are used to bring heat safely and to only heat the specific, designated area inside the body. Due to the fact that heating control in surrounding tissues can be problematic, the nanoparticles are used to increase heating precision by selective nanoparticle accumulation. The next strategy is to use different tissue proprieties, e.g., conductivity, to heat specific tissue type, e.g., by radiofrequency irradiation.

\subsection{Broad Effects on Tumor Cells}

It is worth emphasizing that hyperthermia, just like photodynamic therapy, has a multifactorial effect on cells. Both PDT and hyperthermia as forms of combination cancer treatment seem to give the best results due to synergistic effects that arise when such twomodule treatments are applied. The general scheme of hyperthermia and photodynamic therapy is based on the fact that by increasing the temperature and heating the area where cancer cells are present, which occurs when hyperthermia is used, we increase the amount of mitROS at the same time. This shows that treatment with hyperthermia enhanced the cancer cell-specific PDT activity by increasing the level of mitROS, which led to a reduction in the expression of efflux proteins ABCG2 [206], thereby leading to the accumulation of compounds inside the cell due to the reduced levels of efflux transporters. Another example is the interaction between the hyperthermia used during photodynamic therapy treatment and the presence of the hematoporphyrin derivative. Subsequently, we can examine the following interactions: hyperthermia inhibits the repair of damage that arose as a result of photodynamic therapy, i.e., we can say that there is a cumulative effect aimed at maintaining the damage caused by PDT to achieve better therapeutic results. HpD can accumulate in the tumor, and then it will be excited with laser. During photodynamic therapy and when $\mathrm{HpD}$ accumulation occurs at the time of treatment, when we use additional hyperthermia as another treatment method, a synergistic effect that allows increasing the effectiveness of the treatment can be observed.

The molecular mechanism of cell death in PDT depends on the PS accumulated dose [207], localization of the PS inside the cells or tumor compartments [208,209], PS mechanism of actions [162], oxygen availability [210], light dosage [211], type and places of post-ROS damages [212], cells, and tissue repair potential [213]. Such a mechanism can directly induce cancer cell death. As a result of PDT and hyperthermia, mitochondrial reactive oxygen species (mitROS) are produced, which increase the level of HpD (hematoporphyrin derivative) accumulation in the tumor area. It has been shown that an increase in HpD accumulation stimulates and increases PDT activity. MitROS influences the regulation of the HCP-1 expression (heme carrier protein 1). The aforementioned HpD is a derivative of hematoporphyrin, and in turn, HCP-1 is a heme 1 carrier protein. This protein enables the transport of porphyrins. The use of the two-module therapy, where hyperthermia is applied first, will increase the production of ROS [214], which is important in terms of cancer cell mortality. However, the results indicate that 20-min PDT, where the laser power is $200 \mathrm{~mW} / \mathrm{cm}^{-2}$, and the hyperthermia ranges from $41{ }^{\circ} \mathrm{C}$ to $42{ }^{\circ} \mathrm{C}$ for about $10 \mathrm{~min}$ has some impact on the damage of cancer cells and, consequently, causes 
their death [215]. One may notice its consequences when it comes to the expression of HCP-1 due to the fact that this expression increases, and this allows for more effective transport of porphyrins and their accumulation in cancer cells, which in turn increases the effectiveness of PDT [206]. Furthermore, it has been shown that increasing mitROS not only leads to an increase in HCP-1 expression, but also downregulates the expression of ABCG2 proteins [206]. Overexpression of, among others, these transporters by cancer cells has been identified as a key factor in the development of resistance to chemotherapeutic agents. In addition, $\mathrm{ABCG} 2$ protein (BCRP) has been shown to excrete porphyrins to maintain intracellular porphyrin homeostasis [216]. Tumors can be destroyed using PDT in the following ways: firstly, apoptosis, but also necrosis may occur. Another interesting mechanism of cell death in the context of PDT is the role of autophagy $[217,218]$. Photosensitizers can be given intravenously, intratumorally, or as an ointment to the skin, but they are effectively absorbed and they penetrate quite well. In the context of necrotic areas inside the tumor, researchers have found evidence of PS accumulation in a dose-dependent manner. A high dose during photodynamic therapy, as well as a fairly high concentration of photosensitizer, generally induces cell death in the necrosis pathway. In contrast, low doses of both photosensitizer and light promote cell death through apoptosis [219].

Hyperthermia at the cellular level allows for the induction of cellular stress. In addition, heat can affect cells by damaging them, causing cell death, or elevating their temperature, it can also activate their defense mechanisms [205]. This phenomenon has a significant impact on cells and protein induction. As a result of hyperthermia, heat shock proteins (HSPs) are being induced [220]. It is worth noting that cell membranes are extremely exposed to heat and can be damaged [221]. Hyperthermia primarily reduces the cells repair capacity and, as a consequence, the therapeutic effect increases.

\subsection{Increased Blood Flow in the Tumor}

PDT and hyperthermia also affect blood vessels and blood flow.

It is also postulated that some PDT protocols may induce increased perfusion in tumor tissue due to cell death (this leads to a decrease in the number of cells and decrease in intratumoral pressure) [222] and also leads to stimulation of angiogenesis, as well as angiogenic signaling [223] (e.g., oxygen consumption as a result of a photodynamic reaction may induce an anti-hypoxic mechanism).

As for hyperthermia, the generated heat artificially increases blood flow through the vessels and, thus, affects the drugs used in subsequent treatment. For example, when used in chemotherapy cycles, it is easier for chemotherapy drugs to enter neoplastic cells [191], and the much higher temperature and the increased blood flow sensitize neoplastic cells to chemotherapy [185].

\subsection{Vessels Pruning and Hypoxia}

Some damage to the vessels inside the tumor can lead to damage the tumor itself. In addition, it is important to consider the possibility of changes in the mechanism of action in combination treatment. It must be noted that conducting such a multi-module treatment can give different results and affect the damage of cancer cells or the microenvironment in a different way. To avoid unpredictable effects, the mechanism of the combination treatment should be investigated in vitro and in vivo. It should be mentioned that both PDT and hyperthermia can have dose- and time-dependent results. In the context of cooperation with any form of chemotherapy, hyperthermia can enhance delivery of a drug to an area in which the flow through the blood vessels is more effective. This effect can be used to deliver the photosensitizer to the poorly perfused tumor areas. In the outcome, PDT can be more effective [224]. It is believed that a poorly perfused area can be hypoxic too, and oxygen deficiency can limit the photodynamic reaction. However, changes in blood flow can affect tissue oxygenation as well [225].

In specific cases and conditions, blood vessels may rupture under the influence of photodynamic therapy, especially when the tumor is highly vascularized. This can disrupt 
the supply of nutrients and oxygen to the tumor. For example, PDT can enhance tissue necrosis or induce tissue reoxygenation [21]. Attention should also be paid to the influence on tissue perfusion. Treating patients with PDT hypoxic tissues is still problematic (due to the fact that the molecular oxygen has to be present to perform photodynamic reaction). However, it is postulated that a new generation of photosensitizers and modifications can help solve this problem [226]. It was observed that PDT treatment can induce better oxygenation of cancer at a specific time after treatment and create a "therapeutic window". In this particular time after PDT, some additional therapy, e.g., radiotherapy can be much more effective thanks to the oxygen enhancement effect.

The tumor microenvironment is also critical to hyperthermia. During hyperthermia, i.e., when the temperature in the tumor area increases, blood flow through the vessels may significantly increase, at the same time increasing blood vessel perfusion. This causes an increase in the concentration of nutrients and oxygen; therefore, the area of hypoxia may be eliminated at least for a while. In addition, the tumor hypoxia occurs quite often (low partial pressure of oxygen, generally $<10 \mathrm{mmHg}$ ). The hypoxic area can become more oxygenated due to mild/moderate hyperthermia treatment: heating to several degrees increases the blood flow to the tumor and, thus, increases the oxygen level [227]. Such a pre-treatment can make cells less resistant to radiation therapy. Hyperthermia makes cells more sensitive to radiation [15]. Hypoxia is also crucial in the context of hyperthermia. Hyperthermia can make cells more sensitized and, hence, cause the area of hypoxia to be lifted; this facilitates cell destruction due to hyperthermia.

\subsection{Inflammatory Reaction against Cancer}

Additionally, PDT can induce local inflammation. In this case, it stimulates various pro-inflammatory substances [228]. PDT causes neutrophilia to migrate to a tumor treated with photodynamic therapy, which is associated with the expression of chemokines as well as interleukins [229].

Under the influence of photodynamic therapy, when light is applied and reactive oxygen species are formed, blood vessels dilate, which stimulates the secretion of cytokines and proteins, as well as various growth factors and mediators associated with triggering inflammatory and immune responses. This will stimulate neutrophils and macrophages to migrate to the area where PDT is applied. As a result, according to the research, cancer cells are to be destroyed faster. T-CD4 and T-CD8 lymphocytes, which are known to be cytotoxic, are also activated here.

Thanks to this, the mechanism of apoptosis, i.e., programmed cell death, is activated. PDT, just like hyperthermia, can alert the immune system as well. Increased temperature may lead to increased HSP expression, which also contributes to the activation of the immune system [230]. Significantly increasing the temperature using hyperthermia, it is accompanied by a state of necrosis [231]. As a result of the increased temperature, HSP 70 is activated, which results in the activation of the immune system [232]. In the case of mild hyperthermia, apoptosis is more common [233].

\subsection{Induction of Long-Term Immune Response against Tumor}

The long-term immunological aspect cannot be forgotten either. During cancer treatment, it is very important to remember the immune response [234]. Increasing the temperature stimulates the immune system and has a positive effect on defense mechanisms, which helps in the fight against the disease [235]. It is worth emphasizing that, on the immunological level, hyperthermia allows the activation of immune cells and expression, and influences MHC, both class II and class I [235]. Among the mechanisms present under the influence of the elevated temperature, the role of hyperthermia in regulating expression by increasing MHC class II, CD80, CD86, and CD40 in DCs is worth mentioning [236]. The fact that dendritic cells are involved in this process is also of great significance. NF- $\mathrm{kB}$ is activated on macrophages and dendritic cells, induced by LPS. Additionally, the production 
of cytokines is activated [237]. MHC class I expression on the surface of neoplastic cells is increased [238]. Moreover, the expression of TLR4 is increased as well [235].

\subsection{Targeting Possibility}

The photosensitizers used in PDT and the nanoparticles used in hyperthermia can be targeted to a specific biological mechanism, while at the same time being compatible with the subsequent treatment modality. In the context of combination therapy, chemotherapeutic substances may accumulate more intensively in the neoplastic tissue due to a "therapeutic window" [21]. This method is selective and the issue of combining photosensitizers with nanostructures is increasingly discussed $[239,240]$. An alternative "therapeutic window" mechanism involves creating perfusion/oxygen enhancement in neoplastic tissue. The emergence of various types of nanostructures in cancer therapies, including PDT and hyperthermia, increases the potential for designing effective drug delivery methods to target sites. Such particles may be lipid and polymer nanostructures, nanometal particles, which have the property of attaching targeted ligands, therapeutic agents to their surface, or they may be carriers for therapeutic agents. The use of targeted nanoparticles has the advantage of reduced systemic toxicity [241]. Drugs can be designed to target specific biological structures, such as VEGF receptors [235].

One of the challenge of PDT is to optimize treatment to balance tissue ablation and perfusion enhancement effects. One way to achieve this is to work with the time period between photosensitizer injection (e.g., systemic, intratumoral) and illumination. Therefore, the photosensitizer and light dose can induce different types of effects, e.g., vascular targeted photodynamic therapy (VTP) and cellular targeted photodynamic therapy (CTP) [21] Combined phototherapy with other therapies, e.g., chemotherapy, may bring synergistic therapeutic effects. A frequent target of targeted neoplastic therapies are receptors located on the membranes of neoplastic cells, which are responsible for cell signaling, including various metabolic pathways. They can be inhibited or activated by nanoparticles. However, this is not so simple because of the tumor heterogeneity that makes it difficult to successfully target cancer. Neoplastic cells within the tumor differ from one another, which may mean that the response to a given therapy may differ from cell to cell. This is due to differences in the structure of surface receptors, the expression of receptors on the surface of the cell membrane, the number of receptors, and the fact that different types of cells have completely different sets of receptors. With nanomedicine, it is possible to circumvent this problem by amplifying the tumor target. This can be done in four ways: by increasing the number of existing target molecules, e.g., surface receptors, by targeting the therapy in a double-targeting method, i.e., simultaneous action on two tumor-specific factors, by introducing artificial receptors that are new targets for therapy, and by modifying proteins and peptide building receptors in order to increase their affinity to ligands, which can be used in targeted therapies. Thanks to this type of solutions, we can reduce metastasis and drug resistance of cancer cells [241].

\subsection{Nanomedicine}

Currently, nanomedicine is also used in the context of cancer treatment. It is a very promising field of science. Nanomedicine allows increase of the effectiveness and improves the safety of the standard treatment and diagnostics [242]. Both PDT and hyperthermia use certain aspects of nanomedicine that allow, inter alia, effective treatment, including more effective drug delivery [243]. Research related to the creation of nanoconjugates by combining many chemical compounds, including drugs, with nanoparticles, which are transported and delivered much better to the preferred area of the tumor, is intensively conducted. Additionally, some photosensitizers and nanoparticles used for hyperthermia can be designed to aim at specific biological targets, e.g., VEGF receptors [244]. This brings the opportunity of targeting specific biological mechanisms that can be comprehensive with the next treatment method. Another important biological effect is increasing receptor expression for active targeting, including nanomedicine [245]. 
The use of nanomedicine in PDT translates into a significant improvement in biodistribution of the photosensitizers used and allows very selectively to reach the tumor area, which directly increases the effectiveness of treatment [200]. In the case of PDT, fullerenes can be used, which are commonly known and can act as photosensitizers. Fullerenes as carbon nanomaterials are a great option when it comes to using these materials as a drug carrier [246]. Additionally, liposomes are used in PDT to transport photosensitizers. Liposomes help to reduce the amount of side effects and reach the tumor area more effectively. This is a common nanoscale modification of drug delivery that increases efficacy and benefits drug pharmacokinetics [247]. Moreover, PDT also uses nanotechnology where photosensitizers are modified by adding quantum dots to the system, which also seems to be a great solution [248]. It connects to a photosensitizer, and the task of quantum dots is to target and deliver photosensitizers directly to cells, providing additional enhancement in drug transport to the desired therapeutic area [249].

Hyperthermia is also of great importance in nanomedicine. Therapeutic protocols are constantly being improved and treatments using this technique are modified. The main focus is on the use of nanoparticles to influence local or systemic heat generation. For this purpose, gold nanoparticles can be used, which are characterized by the ability to absorb light in the near-infrared range, which allows the tumor to be heated. Moreover, it is also postulated that nanogold can increase the doses of X-ray radiation in the tumor area [250]. Another very interesting nanoparticle can be silver, whose task is also to generate an appropriate amount of heat, which allows the drugs to penetrate deeper into cells or tissues [251]. On the other hand, silver nanoparticles can also be used in specialized wound dressings resulting from hyperthermia [251]. Additionally, ferromagnetics are used in the case of magnetic hyperthermia. $\mathrm{Ni}-\mathrm{Cu}$ is an example of a molecule that can be used for this purpose. Low concentrations are not toxic, in high concentrations, a toxic effect on neoplastic cells is observed [252]. Another interesting aspect of nanomedicine and nanotechnology is the use of nano thermometers that can determine the temperatures of solutions and biological systems, even at the cellular level [253]. The general principle of operation of such a thermometer is based on the use of nanoparticles that are thermosensitive to fluorescence and capture the change in fluorescence intensity [253].

All this means is that PDT and hyperthermia contribute toward increasing the effectiveness of cancer treatment. These are complementary methods, since their use reduces the side effects of drug delivery in the case of chemotherapy, and reduces cell resistance to radiation, but also because these methods are definitely less harmful by themselves [238]. We claim that these therapies seem to be a good solution for combination therapy and should be explored by clinicians more deeply. Based on scientific evidence, these methods undoubtedly increase the effectiveness and efficiency of therapy. In summary, the phenomenon of PDT and hyperthermia treatment is similar-both therapies can alert cancer on a cellular level and induce cell death. These therapies can also impact tissue perfusion and influence tissue oxygenation (hypoxia) through reducing or increasing the nutrients. They can also induce a local and systemic immune reaction.

\section{What Other Methods Are PDT and Hyperthermia Combined with?}

PDT and hyperthermia as an anti-cancer treatments are most often associated with radiotherapy, chemotherapy, immunotherapy, and surgery (Table 3). These methods can be applied in various combinations. The combination of only two methods and a multi-module treatment can be equally effective. It all depends on the type of cancer, its aggressiveness, metastasis, location, and the therapeutic effect we want to achieve. In order to select the appropriate and optimal treatment methods to achieve the best possible results, all of these factors should be considered [254,255].

The treatment time window should be taken into very careful consideration. In general, a "treatment window" induced by a therapy occurs and lasts for a specific time after the treatment [256]. A treatment combining hyperthermia, chemotherapy, and/or radiation therapy is quite often used in clinics. In this connection, hyperthermia primarily plays 
the role of reoxygenation of cancerous tumors. Thus, tumor reoxygenation may enhance a positive response to radiotherapy [257], as well as sensitize cells to chemotherapy. It was also shown that, in pancreatic cancer, the combination of gemcitabine with cisplatin and hyperthermia gave better results than monotherapy [258]. In contrast, a triple modal treatment was used in a clinical trial of an advanced cervical cancer. It was shown that $74 \%$ of patients survived without any recurrence symptoms, and an additional 5-year overall survival rate amounted to $66.1 \%[259,260]$

PDT, on the other hand, can be used in conjunction with surgery as a neoadjuvant, adjuvant, or repetitive adjuvant treatment, and it is also successfully combined with radiation and chemotherapy. For example, apoptosis-modulating factors, such as rapamycin, Bcl-2 antagonists, and others have been shown to increase PDT-mediated cancer cell death. The combination of PDT and radiation therapy leads to the strengthening of anti-cancer effects. For example, the combination of photodynamic therapy and high-dose brachytherapy in patients with symptomatic lung cancer was tolerated well and gave satisfactory results [261].

Table 3. Combined clinical therapies, including hyperthermia and photodynamic therapy.

\begin{tabular}{|c|c|c|c|c|c|c|c|c|}
\hline \multicolumn{9}{|c|}{ Hyperthermia in Combinatory Anticancer Treatment } \\
\hline $\begin{array}{l}\text { Schema of } \\
\text { Combinatory } \\
\text { Treatment }\end{array}$ & Cancer & $\begin{array}{c}\text { Stage of } \\
\text { Trial }\end{array}$ & Country & $\begin{array}{c}\text { Study Start } \\
\text { Date-Study } \\
\text { Completion } \\
\text { Date }\end{array}$ & Enrollment & Results of Trials & $\begin{array}{l}\text { ClinicalTrial. } \\
\text { Gov ID }\end{array}$ & Ref. \\
\hline $\begin{array}{c}\mathrm{H}(\mathrm{FRWBH})+ \\
\quad \mathrm{R}+\mathrm{CH}\end{array}$ & $\begin{array}{l}\text { Head and } \\
\text { neck cancer }\end{array}$ & 1 phase & Germany & 2018-2020 & 10 & $\begin{array}{l}\text { The median LRC and OS of } \\
\text { all included patients* was } 10 \\
\text { and } 9 \text { months, respectively. } \\
\text { * Due to COVID-19 only } 5 \\
\text { patients received all cycles of } \\
\text { Fever-range whole body } \\
\text { hyperthermia (FRWBH). }\end{array}$ & $\begin{array}{c}\text { NCT03547388 } \\
\text { [262] }\end{array}$ & {$[263,264]$} \\
\hline $\begin{array}{c}\mathrm{H}+\mathrm{CH}+\mathrm{S} \\
\text { (HIPEC + } \\
\text { CRS) }\end{array}$ & $\begin{array}{l}\text { Gastric } \\
\text { cancer }\end{array}$ & 1 phase & $\begin{array}{l}\text { United } \\
\text { States }\end{array}$ & 2016-2018 & 4 & 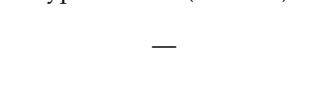 & $\begin{array}{c}\text { NCT02672865 } \\
\text { [265] }\end{array}$ & - \\
\hline $\mathbf{H}+\mathbf{C H}$ & $\begin{array}{l}\text { Bladder } \\
\text { cancer }\end{array}$ & $\begin{array}{l}1 \text { phase } \\
\text { (early) }\end{array}$ & $\begin{array}{l}\text { United } \\
\text { States }\end{array}$ & 2008-2011 & 15 & $\begin{array}{l}\text { With a median follow-up of } \\
3.18 \text { years, } 67 \% \text { experienced } \\
\text { another bladder cancer } \\
\text { recurrence (none were } \\
\text { muscle invasive) and } 13 \% \\
\text { experienced an upper tract } \\
\text { recurrence. }\end{array}$ & $\begin{array}{c}\text { NCT00734994 } \\
\text { [266] }\end{array}$ & [267] \\
\hline $\begin{array}{c}\mathrm{H}+\mathrm{CH}+\mathrm{S} \\
(\mathrm{IPHC}+\mathrm{CRS})\end{array}$ & $\begin{array}{l}\text { Appendix } \\
\text { cancer } \\
\text { colorectal } \\
\text { cancer }\end{array}$ & 1 phase & $\begin{array}{l}\text { United } \\
\text { States }\end{array}$ & $2007-2007$ & 16 & 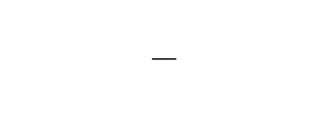 & $\begin{array}{c}\text { NCT00458809 } \\
\text { [268] }\end{array}$ & [269] \\
\hline $\begin{array}{c}\mathrm{H}+\mathrm{S}+\mathrm{CH} \\
(\mathrm{HIPEC})\end{array}$ & $\begin{array}{l}\text { Peritoneal } \\
\text { cavity } \\
\text { cancer }\end{array}$ & 1 phase & $\begin{array}{l}\text { United } \\
\text { States }\end{array}$ & $2007-2011$ & 17 & - & $\begin{array}{c}\text { NCT00625092 } \\
{[270]}\end{array}$ & - \\
\hline $\mathbf{H}+\mathbf{C H}+\mathbf{L S}$ & Lung cancer & 1 phase & $\begin{array}{l}\text { United } \\
\text { States }\end{array}$ & 1999-? & - & - & $\begin{array}{c}\text { NCT00020007 } \\
{[271]}\end{array}$ & - \\
\hline $\mathrm{H}+\mathrm{TT}$ & Liver tumor & 1 phase & $\begin{array}{l}\text { United } \\
\text { Kingdom }\end{array}$ & 2014-2017 & 10 & - & $\begin{array}{c}\text { NCT02181075 } \\
\text { [272] }\end{array}$ & [273-275] \\
\hline $\mathrm{S}+\underset{\text { IT }}{\text { HIPEC }}+$ & $\begin{array}{c}\text { Ovarian } \\
\text { adenocarci- } \\
\text { noma } \\
\text { fallopian } \\
\text { tube adeno- } \\
\text { carcinoma, } \\
\text { primary } \\
\text { peritoneal } \\
\text { carcinoma }\end{array}$ & 1 phase & France & 2011-2015 & 30 & $\begin{array}{l}\text { With a median follow-up of } \\
29.3 \text { months since the } \\
\text { diagnosis and } 23 \text { months } \\
\text { after CCRS + HIPEC. } \\
\text { Median DFS from CCRS + } \\
\text { HIPEC was } 16.7 \text { months and } \\
\text { after CCRS + HIPEC, } 2 \text {-year } \\
\text { DFS and OS were } 27 \% \text { and } \\
71 \% \text {, respectively. The } \\
\text { median PFS was } 16.7 \\
\text { months after surgery. }\end{array}$ & $\begin{array}{c}\text { NCT02217956 } \\
{[276]}\end{array}$ & [277] \\
\hline $\mathrm{H}+\mathrm{DT}$ & $\begin{array}{l}\text { Non-small } \\
\text { cell lung } \\
\text { cancer }\end{array}$ & $\begin{array}{l}1 \text { phase } \\
2 \text { phase }\end{array}$ & $\begin{array}{l}\text { United } \\
\text { States }\end{array}$ & 2015-2018 & $\begin{array}{c}29 \\
(\text { Trial A = 18 } \\
\text { Trial B = 11) }\end{array}$ & $\begin{array}{l}\text { The median OS for the active } \\
\text { arm was } 9.4 \text { months and for } \\
\text { the control arm was } 5.6 \\
\text { months. The median PFS for } \\
\text { the active arm was } 3.0 \\
\text { months and for the control } \\
\text { arm was } 1.85 \text { months. } \\
\text { In Trial A: TTLP, PFS and OS } \\
\text { was } 4.9,4.8,9.0 \text { months, } \\
\text { respectively.In trial B: } 6 \text { of } 11 \\
\text { patients had a clinically } \\
\text { significant quality of life } \\
\text { (QoL) improvement. }\end{array}$ & $\begin{array}{c}\text { NCT00346229 } \\
\text { (trial A) [281] } \\
\text { NCT00826085 } \\
\text { (trial B) [282] }\end{array}$ & {$[279,280]$} \\
\hline
\end{tabular}


Table 3. Cont.

\begin{tabular}{|c|c|c|c|c|c|c|c|c|}
\hline \multicolumn{9}{|c|}{ Hyperthermia in Combinatory Anticancer Treatment } \\
\hline $\begin{array}{l}\text { Schema of } \\
\text { Combinatory } \\
\text { Treatment }\end{array}$ & Cancer & $\begin{array}{c}\text { Stage of } \\
\text { Trial }\end{array}$ & Country & $\begin{array}{c}\text { Study Start } \\
\text { Date-Study } \\
\text { Completion } \\
\text { Date }\end{array}$ & Enrollment & Results of Trials & $\begin{array}{l}\text { ClinicalTrial. } \\
\text { Gov ID }\end{array}$ & Ref. \\
\hline $\begin{array}{c}\mathrm{H}+\mathrm{CH}+\mathrm{S} \\
(\mathrm{HIPEC}+ \\
\text { CRS })\end{array}$ & $\begin{array}{l}\text { Colorectal } \\
\text { cancer }\end{array}$ & $\begin{array}{l}1 \text { phase } \\
2 \text { phase }\end{array}$ & Italia & 2006-2010 & 20 & $\begin{array}{l}\text { Median follow-up was } 65.2 \\
\text { months in the HIPEC group } \\
\text { and } 34.5 \text { months in the } \\
\text { control group. } 5 \text {-year overall } \\
\text { survival (OS) was } 81.3 \% \text { in } \\
\text { the HIPEC group versus } \\
70.0 \% \text { in the control group. }\end{array}$ & $\begin{array}{c}\text { NCT02575859 } \\
\text { [284] }\end{array}$ & [285] \\
\hline $\begin{array}{c}\mathrm{H}+\mathrm{CH}+\mathrm{S} \\
(\mathrm{HIPEC}+ \\
\text { CRS })\end{array}$ & $\begin{array}{c}\text { Peritoneal } \\
\text { carcinomatosis }\end{array}$ & $\begin{array}{l}1 \text { phase } \\
2 \text { phase }\end{array}$ & France & $2007-2011$ & 18 & 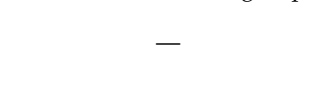 & $\begin{array}{l}\text { NCT01226550 } \\
\text { [286] }\end{array}$ & - \\
\hline$\underset{\mathrm{CH}}{\mathrm{H}+\mathrm{R}+\mathrm{S}+}$ & Sarcoma & $\begin{array}{l}1 \text { phase } \\
2 \text { phase }\end{array}$ & $\begin{array}{l}\text { United } \\
\text { States }\end{array}$ & 1999-2007 & 15 & - & $\begin{array}{c}\text { NCT00093509 } \\
\text { [287] }\end{array}$ & [288] \\
\hline $\begin{array}{l}\mathrm{H}+\mathrm{CH}+\mathrm{S}+ \\
\mathrm{CH}(\mathrm{HIPEC}+ \\
\quad \mathrm{S}+\mathrm{CH})\end{array}$ & $\begin{array}{l}\text { Ovarian } \\
\text { carcinoma, } \\
\text { fallopian tube } \\
\text { carcinoma, } \\
\text { primary } \\
\text { peritoneal } \\
\text { carcinoma }\end{array}$ & $\begin{array}{l}1 \text { phase } \\
2 \text { phase }\end{array}$ & Belgium & 2010-2015 & 19 & $\begin{array}{l}\text { The median follow-up was } \\
30.9 \text { and the median PFS was } \\
33.2 \text { months. The OS } \\
\text { survival was not reached. }\end{array}$ & $\begin{array}{c}\text { NCT01709487 } \\
\text { [289] }\end{array}$ & [290] \\
\hline $\begin{array}{c}\mathrm{H}+\mathrm{CH}+\mathrm{S}+ \\
\mathrm{CH}(\mathrm{HIPEC}+ \\
\mathrm{S}+\mathrm{CH})\end{array}$ & $\begin{array}{l}\text { Colorectal } \\
\text { cancer }\end{array}$ & 2 phase & China & $2016-2020$ & 100 & - & $\begin{array}{c}\text { NCT02830139 } \\
{[291]}\end{array}$ & - \\
\hline $\begin{array}{c}\mathrm{H}+\mathrm{CH}+\mathrm{S}+ \\
\mathrm{CH}(\mathrm{HIPEC}+ \\
\mathrm{S}+\mathrm{CH})\end{array}$ & $\begin{array}{l}\text { Stomach } \\
\text { cancer }\end{array}$ & 2 phase & China & $2015-2020$ & 100 & - & $\begin{array}{c}\text { NCT02528110 } \\
\text { [292] }\end{array}$ & - \\
\hline $\mathrm{H}+\mathrm{CH}+\mathrm{R}$ & Rectal cancer & 2 phase & Germany & 2012-2017 & 78 & $\begin{array}{c}\text { 3-year evaluate for OS, DFS, } \\
\text { LC and DC were } 94 \%, 81 \% \text {, } \\
96 \% \text {, and } 87 \% \text {, respectively. } \\
\text { Higher cumulative } \\
\text { temperatures associated } \\
\text { with hyperthermia indicated } \\
\text { stronger tumor regression in } \\
\text { patients. }\end{array}$ & $\begin{array}{c}\text { NCT02353858 } \\
\text { [293] }\end{array}$ & [294]. \\
\hline $\begin{array}{c}\mathrm{H}+\mathrm{CH}+\mathrm{S} \\
(\mathrm{HIPEC}+\mathrm{LS})\end{array}$ & $\begin{array}{l}\text { Gastrointestinal } \\
\text { cancer }\end{array}$ & 2 phase & $\begin{array}{l}\text { United } \\
\text { States }\end{array}$ & 2014-2020 & 21 & $\begin{array}{l}\text { The median OS from the } \\
\text { date of diagnosis of } \\
\text { metastatic disease was } 30.2 \\
\text { months. The median OS } \\
\text { from the first laparoscopic } \\
\text { HIPEC was } 20.3 \text { months. } \\
\text { With a median follow-up of } \\
70 \text { months (18-110 months) } \\
\text { 7-year OS was } 94 \% \text { with } 61 \% \\
\text { of patient failure free. }\end{array}$ & $\begin{array}{c}\text { NCT02092298 } \\
\text { [295] }\end{array}$ & [296,297] \\
\hline $\begin{array}{c}\mathrm{H}+\mathrm{CH}+\mathrm{S} \\
(\mathrm{HIPEC}+ \\
\text { CRS })\end{array}$ & $\begin{array}{l}\text { Desmoplastic } \\
\text { small round } \\
\text { cell tumor } \\
\text { (DSRCT) } \\
\text { sarcoma }\end{array}$ & 2 phase & $\begin{array}{l}\text { United } \\
\text { States }\end{array}$ & 2011-2018 & 22 & $\begin{array}{l}\text { The estimated median OS } \\
\text { from the time of diagnosis } \\
\text { was } 58.44 \text { months (for } 20 \\
\text { patience). }\end{array}$ & $\begin{array}{c}\text { NCT01277744 } \\
{[300]}\end{array}$ & [301] \\
\hline $\begin{array}{l}\text { CRS + HIPEC } \\
+ \text { EPIC }\end{array}$ & $\begin{array}{l}\text { Peritoneal } \\
\text { carcinomatosis } \\
\text { gastric cancer }\end{array}$ & 2 phase & Sweden & 2005-2009 & 18 & $\begin{array}{l}\text { The OS was } 14.3 \text { months for } \\
8 \text { patients who received } \\
\text { entire treatment. The } \\
\text { median OS for the CRS + } \\
\text { HIPEC + EPIC group of } \\
\text { patience was } 10.2 \text { months. } 6 \\
\text { patients had macroscopically } \\
\text { radical surgery (CCO) and } \\
\text { for this subgroup OS was } \\
19.1 \text { months. }\end{array}$ & $\begin{array}{c}\text { NCT01379482 } \\
\text { [302] }\end{array}$ & [303] \\
\hline $\begin{array}{c}\mathrm{H}+\mathrm{CH}+\mathrm{S} \\
(\mathrm{HIPEC}+ \\
\text { CRS })\end{array}$ & $\begin{array}{l}\text { Peritoneal } \\
\text { carcinomatosis, } \\
\text { colorectal } \\
\text { cancer, } \\
\text { appendiceal } \\
\text { cancer } \\
\text { peritoneal } \\
\text { mesothelioma, } \\
\text { pseudomyx- } \\
\text { oma peritonei, } \\
\text { gastric cancer }\end{array}$ & 2 phase & $\begin{array}{l}\text { United } \\
\text { States }\end{array}$ & 2011-2020 & 51 & - & $\begin{array}{c}\text { NCT02040142 } \\
{[304]}\end{array}$ & - \\
\hline
\end{tabular}


Table 3. Cont.

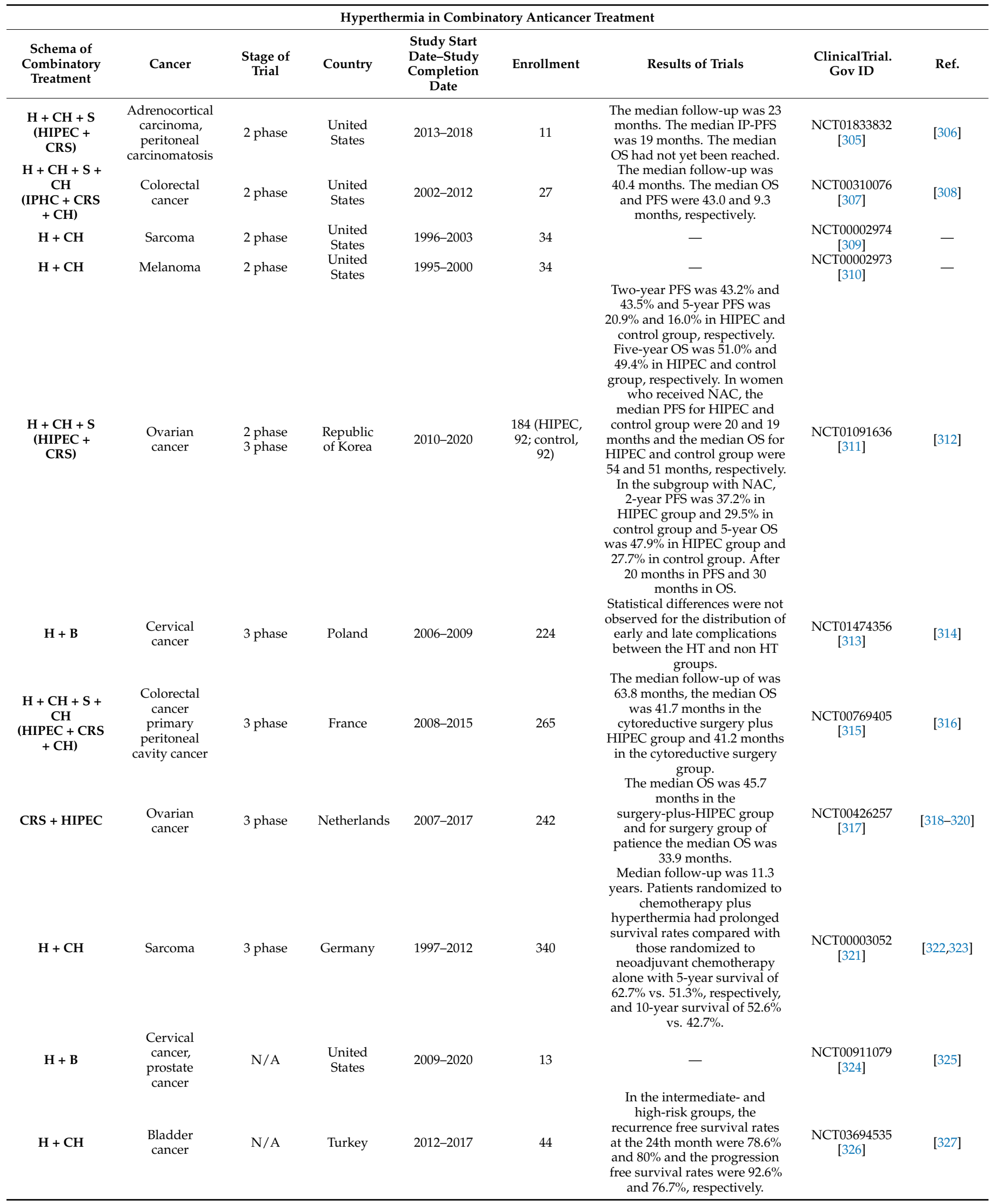


Table 3. Cont.

\begin{tabular}{|c|c|c|c|c|c|c|c|c|}
\hline \multicolumn{9}{|c|}{ Hyperthermia in Combinatory Anticancer Treatment } \\
\hline $\begin{array}{l}\text { Schema of } \\
\text { Combinatory } \\
\text { Treatment }\end{array}$ & Cancer & $\begin{array}{l}\text { Stage of } \\
\text { Trial }\end{array}$ & Country & $\begin{array}{c}\text { Study Start } \\
\text { Date-Study } \\
\text { Completion } \\
\text { Date }\end{array}$ & Enrollment & Results of Trials & $\begin{array}{l}\text { ClinicalTrial. } \\
\text { Gov ID }\end{array}$ & Ref. \\
\hline PDT + TT & $\begin{array}{l}\text { Basal cell } \\
\text { carcinoma }\end{array}$ & 1 phase & $\begin{array}{l}\text { United } \\
\text { States }\end{array}$ & 2015-2017 & 4 & $\begin{array}{l}\text { ORR showed } 90 \% \text { CR and } \\
10 \% \text { PR for the study. } \\
\text { The median follow-up of }\end{array}$ & $\begin{array}{c}\text { NCT02639117 } \\
{[328]}\end{array}$ & [329] \\
\hline $\mathrm{PDT}+\mathrm{CH}$ & Pancreatic cancer & 1 phase & $\begin{array}{l}\text { United } \\
\text { States }\end{array}$ & 2013-2018 & 12 & $\begin{array}{l}10.5 \text { months, PFS and OS } \\
\text { were } 2.6 \text { months and } 11.5 \\
\text { months, respectively. }\end{array}$ & $\begin{array}{c}\text { NCT01770132 } \\
{[330]}\end{array}$ & [331] \\
\hline $\mathrm{PDT}+\mathrm{S}$ & $\begin{array}{l}\text { Non-small cell } \\
\text { lung cancer }\end{array}$ & 1 phase & $\begin{array}{l}\text { United } \\
\text { States }\end{array}$ & 2014-2018 & 8 & - & $\begin{array}{l}\text { NCT01854684 } \\
\text { [332] }\end{array}$ & - \\
\hline $\mathrm{PDT}+\mathrm{S}$ & $\begin{array}{l}\text { Head and neck } \\
\text { cancer }\end{array}$ & 1 phase & $\begin{array}{l}\text { United } \\
\text { States }\end{array}$ & 2006-2018 & 15 & $\begin{array}{l}\text { The clinical follow-up visits } \\
\text { at } 48 \text { months showed OS of } \\
10 \text { patients and PFS of } 7 \\
\text { patients. } \\
\text { The primary objective was to } \\
\text { determine the safety of } \\
\text { HPPH-mediated } \\
\text { intraoperative adjuvant PDT } \\
\text { immediately after tumor } \\
\text { resection and to determine } \\
\text { the highest dose of laser } \\
\text { light that can be safely used } \\
\text { in treatment. }\end{array}$ & $\begin{array}{l}\text { NCT00470496 } \\
{[333]}\end{array}$ & [334] \\
\hline $\mathrm{PDT}+\mathrm{B}$ & Lung cancer & 1 phase & $\begin{array}{l}\text { United } \\
\text { States }\end{array}$ & 1993-2004 & - & - & NCT00014066 & - \\
\hline PDT + ER & $\begin{array}{l}\text { Early cancer in } \\
\text { Barrett's esophagus }\end{array}$ & 2 phase & $\begin{array}{l}\text { United } \\
\text { States }\end{array}$ & 2005-2012 & 73 & - & $\begin{array}{c}\text { NCT00217087 } \\
{[336]}\end{array}$ & - \\
\hline $\mathrm{PDT}+\mathrm{S}$ & $\begin{array}{l}\text { Malignant } \\
\text { mesothelioma }\end{array}$ & 2 phase & $\begin{array}{l}\text { United } \\
\text { States }\end{array}$ & 1999-2010 & 12 & - & $\begin{array}{c}\text { NCT00054002 } \\
{[337]}\end{array}$ & - \\
\hline $\mathrm{PDT}+\mathrm{S}$ & $\begin{array}{l}\text { Non-melanoma } \\
\text { Skin cancer }\end{array}$ & 2 phase & $\begin{array}{l}\text { United } \\
\text { States }\end{array}$ & 1993-2007 & - & - & $\begin{array}{c}\text { NCT00002963 } \\
{[338]}\end{array}$ & - \\
\hline $\mathrm{PDT}+\mathrm{CH}$ & $\begin{array}{c}\text { Perihilar } \\
\text { cholangiocarcinoma }\end{array}$ & 3 phase & $\begin{array}{l}\text { Republic } \\
\text { of Korea }\end{array}$ & 2009-2013 & 43 & $\begin{array}{l}\text { Patients treated with } \\
\text { combinatory therapy } \\
\text { showed higher 1-year SR } \\
\text { compared with the patients } \\
\text { treated with PDT alone: } \\
76.2 \% \text { vs. } 32 \% \text { and median } \\
\text { prolonged OS was } 17 \\
\text { months vs. } 8 \text { months. } \\
\text { Median PFS for combinatory } \\
\text { treatment was } 10 \text { months } \\
\text { and for patients with PDT } \\
\text { alone was } 2 \text { months. }\end{array}$ & $\begin{array}{c}\text { NCT00869635 } \\
{[339]}\end{array}$ & [340] \\
\hline
\end{tabular}

Table 3 completed, interventional clinical trials involving hyperthermia and PDT in combination therapy in cancer patients. Information was retrieved from ClinicalTrials.gov (last assessed on 26 April 2021), by searching for 'condition or disease: 'cancer', other terms: 'hyperthermia' or 'PDT', status recruitment: 'completed', study type: 'interventional studies (Clinical Trials)'. Schema of combinatory treatments: H-hyperthermia, R-radiotherapy, CH-chemotherapy. PDT-photodynamic therapy, TT-target therapy, S-surgery, DT-drug therapy, B-brachytherapy, ER — endoscopic resection, LS-laparoscopic surgery, FRWBH-fever-range whole body hyperthermia, CRScytoreductive surgery, HIPEC - hyperthermic intraperitoneal chemotherapy, EPIC_early postoperative intraperitoneal chemotherapy, IT-immunotherapy. * (Local regional control (LRC), progression-free Survival (PFS), overall Survival (OS), time to local progression (TTLP), local control (LC), distant control (DC), disease-free survival (DFS), overall response rate (ORR), complete response (CR), partial response $(P R)$, survival rate $(S R)$, not applicable $(\mathrm{N} / \mathrm{A})$ ).

\subsection{The Synergistic Effect}

The general idea of synergy is the interaction of various factors. Furthermore, in the context of cancer treatment, it involves cooperation of therapeutic methods. The difference between a synergistic and an additive action is that in synergy, the mechanism is based on mutual influence, while in the case of additivity, it involves adding individual methods and their effect. Synergistic effects should have a greater impact and should give better results than the sum of individual methods used in treatment-this is where the new treatment quality emerges. Considering the phenomenon of the synergistic effect, in the context of treatment it can be defined as strengthening the mutual effects of methods in cases where various treatment techniques are applied in a multi-module or combined approach. This approach is designed to strengthen the desired therapeutic results. These results arise only when we are dealing with a minimum of two factors, two substances, or-in the context of therapeutic treatment-two methods. Undoubtedly, the synergistic effect increases the effectiveness of the therapy. It is an important approach that stands behind combination 
therapy, since modular operation allows the initiation of a cascade, which has a positive effect on the effectiveness of treatment. Of course, the synergistic effect does not always have to be positive. Unfortunately site effects can get enhanced as well. Nevertheless, the aim of designing combination treatment is to enhance anti-cancer modalities and, at the same time, reduce harmful effects of the treatment.

When achieving a synergistic effect by combining different therapies, we can attain inhibition of cancer cell proliferation, destruction of the cytoskeleton and, thus, increase the chance of apoptosis. It also results in damaging blood vessels, reducing the resistance of cancer cells to chemotherapy or radiation. In addition, it strengthens the mechanisms of action of the drugs used. The concept of synergy is quite often an issue when combining chemotherapeutics with different mechanisms of action. Cisplatin, gemcitabine, or vinorelbine can also be combined with proteasome inhibitors in the treatment of lung cancer. According to scientific research, we can achieve quite good results using the above method. Additionally, interesting effects can be obtained by using abraxane and gemcitabine. The scheme of action using these two drugs was as follows: first nab-paclitaxel was injected into the mice, and then gemcitabine. The time interval between the injections of these drugs was $2 \mathrm{~h}$. This treatment procedure was performed in six cycles. In this experiment, radio frequency electromagnetic radiation (called radio frequency-RF) was used. The use of RF allowed inducing hyperthermia in the tumor area. The experiment showed the effectiveness of such a treatment. A reduction in the size of the PANC-1 orthotopic tumors was observed [341]. On the other hand, murine 4T1 tumors with a low degree of vascularization were characterized by the greatest functional increase in the vascular system after the use of hyperthermia, which, according to the authors, may be beneficial in a treatment involving the use of chemotherapy [342]. On the other hand, with regard to PDT, hyperthermia can cause tumor blood vessel damage that would affect angiogenesis and, like PDT, damage cell membranes, which could allow the occurrence of a synergistic effect between these two approaches [343].

When discussing the results of synergistic effects, it is usually worth emphasizing that, when treating cancer with the use of different methods, the overall idea is to act sequentially. One method should complement and strengthen the previously used one. What is important is that this approach allows using a smaller dose of a drug, a chemotherapy agent, and a photosensitizer or radiation, and it can reduce the side effects of the therapy. It is worth emphasizing that, when synergistic effects occur, they increase irreversible damage (e.g., by affecting cell repair abilities) and radiosensitivity, there is also an increase in regard to the sub-lethal damage. Different mechanisms can be alerted too, e.g., one therapy component can first induce immune response, then it can act as an anti-angiogenic agent, and then-target cancer cells. In addition, inhibition of repair of any damage may occur, as well as an increase in the sensitivity of hypoxic cancer cells. The increase in the concentration of chemotherapeutics inside the tumor is also significant.

\subsection{Attempts to Treat Tumors with PDT and Hyperthermia}

Scientific research, publications, and scientific articles describe treatment by photodynamic therapy and hyperthermia on cancers, such as skin cancers (e.g., melanomas, ocular melanoma, colon, bladder, esophageal, breast, head and neck, lung cancers) $[344,345]$. It is difficult to find information about research connected with treatment with the use of PDT and hyperthermia in the context of treating cancers associated with the cardiovascular system and the circulatory system, such as leukemia. Therefore, knowing the specifics and general principle of these two methods, the cancers of choice are either on the surface of the skin, i.e., in this case any cancerous lesions of a melanoma nature, or inside the body. PDT, as well as hyperthermia, thanks to the use of probes, allow for quite precise access to a given area that is to be treated $[227,346,347]$ In addition, these methods are also used to treat organs, such as liver, lungs, or pancreas that are relevant to our bodies, and within which, tumorous lesions were detected in locations where surgery is not an option due to the fact that it is quite easy to damage such extremely important structures. Due to the 
fact that PDT and hyperthermia are treated as complementary therapies, these methods are also used in the context of solid tumors and primary tumors, but also in the context of treating malignant tumors that have a tendency to metastasis. Therefore, it seems that attempts to treat cancers with photodynamic therapy or hyperthermia are practiced on most common cancers [347,348].

\section{Combination Therapy's Effect on Drug Uptake and Delivery}

Hyperthermia and photodynamic therapy play a significant role in drug delivery and absorption during cancer treatment. Hyperthermia can possibly change the level of drug delivery. It can break and unblock certain restrictions related to the tumor location or structure. Moreover, it can alter the cytoskeleton itself. Temporary damage to the cytoskeleton causes deformation of cells and vessels surrounding the tumor, which in turn facilitates the drug transport [349]. It is also worth emphasizing that hyperthermia increases the permeability of blood vessels [350], which significantly affects the delivery of drugs to the area of the neoplastic lesion and improves the effectiveness of the drugs used. The efficacy of drug delivery in cancer treatment therapies is deliberately improving. Targeted treatment [351], where innovative and modern carriers are used to make the uptake, absorption, and transport of drugs within the neoplastic lesion to be much more effective, seems to be a good approach. This approach allows getting rid of many negative and undesirable side effects associated with drug distribution and toxicity. PDT combined with other therapies, for example with chemotherapy, allows the use of a much lower dose of the chemotherapeutic in most of the cases [352]. The problem with drug resistance is significantly reduced, and once again we are dealing with a reduced toxicity. Due to the synergistic effects caused by the use of these therapeutic methods, the dose required to obtain the desired therapeutic effects can be lowered. Any modification of drugs and their delivery, for example by liposomes during hyperthermia or PDT, significantly influences drug absorption as well. This approach ensures efficient delivery and bounding the drug in the tumor region, which significantly affects cancer cells and causes cell damage [353]. A therapy involving the use of the thermal aspect may also increase the rate of drug release in a given area where the temperature will rise significantly [354]. There is an important issue in the context of drug transport related to thermoablation. It is interesting that under the influence of high temperature, which can be induced by hyperthermia, it is possible to increase the proliferation of cancer cells by activating various pro-tumorigenic factors [355]. Normalization as part of PDT is also worth mentioning. The normalization effect is based on the fact that there is a temporary normalization of blood vessels, both in terms of their structure and function [356]. This creates an individual therapeutic window through which a better therapeutic result can be obtained. In the context of normalization of vessels with PDT, there is also an issue related to the delivery of certain substances to the vicinity of neoplastic tissue. These substances are supposed to work against excessive angiogenesis. Anti-VEGF angiogenesis inhibitors are designed to restore some degree of regularity in damaged, deformed, and leaky blood vessels, and to increase the oxygenation of the tissue surrounding the tumor [357]. The occlusion of blood vessels that occurs with the use of these therapies is extremely important [358]. Under the influence of the increased temperature, the neoplastic tissue increases in volume due to hyperthermia. As a result, the pressure inside the tumor changes. When pressure in the tumor area is lowered, a leakage occurs. As a result, the pressure around the tissue rises. Moreover, a properly selected combination therapy should ideally ensure that the drug is first delivered under the influence of the generated heat, and after the occlusion of the blood vessels, the therapeutic substance is closed inside the tumor due to the vascular pruning mechanism. It is worth emphasizing that attempts are being made to include nanoparticles in the diagnosis, for example quantum dots, and in the treatment of cancer. In particular, they enable more effective detection of early lesions and early stages of cancer. In addition, the use of nanogold contributes to the drug distribution if a construct with nanoparticles is used in the tumor area. Besides, the treatment effectiveness can be 
increased by combining nanoparticles with antibodies. This is a fairly promising approach. Nanoparticles can be used in many therapies. When it comes to combining nanoparticles with chemotherapy, this approach is primarily intended to increase the efficiency of the delivery of a chemotherapeutic drug specifically to the tumor area [359]. As a result, the effectiveness of treatment may increase, and due to the fact that we act specifically, it is possible to reduce the side effects associated with the toxicity of chemotherapeutics. When it comes to radiation therapy and combining this method of cancer treatment with nanoparticles, then the task of nanoparticles is to sensitize cancer cells. For example, gold nanoparticles can increase the effectiveness of radiation therapy due to the fact that the production of free radicals increases in a specific place, therefore the area becomes more oxidized, the level of hypoxia decreases, and cells are more sensitive to a given dose of ionizing radiation. Nanoparticles have their place in PDT as well [360]. Photosensitizer carriers have been created, which are able to reach the tumor area much more effectively than regular carriers. In the context of hyperthermia, it is quite common to use nanoparticles that exhibit magnetic properties. As a result, they are used as an alternative source of energy in this therapy [361]. Gold nanoparticles in the context of hyperthermia are also used in thermoablation. This phenomenon allows the destruction of tumors. In general, nanotechnology is beginning to play a significant and important role in the context of cancer treatment, and combining nanoparticles with methods that are currently used in treatment is now much more common [362]. This gives promising results for the future and thanks to the use of nanoparticles, it is possible to treat patients more effectively and minimize the side effects of therapy. Considering all of these aspects, it can be clearly stated that both hyperthermia and photodynamic therapy are beneficial in terms of drug delivery. The use of the above-mentioned therapeutic methods makes the therapeutic effect more beneficial, and the issue of drug delivery and better absorption can be improved.

\section{Photodynamic Therapy and Hyperthermia in Combination Treatment}

PDT and hyperthermia can also be combined. Particularly, hyperthermia could solve the issue of hypoxia for PDT. In studies on rat tumors, Kelleher et al. demonstrated that combined treatment, which consists of conducting photodynamic therapy based on aminolevulinic acid (ALA-PDT) simultaneously with local hyperthermia at $43{ }^{\circ} \mathrm{C}$, is more effective than the sum of its components [363]. In addition, vascular collapse and flow stasis were shown to be a key element in tumor elimination in combined hyperthermia and chlorophyll photodynamic therapy (Bchl-ser-PDT), resulting in lower tumor oxygenation and a switch from oxidative to glycolytic glucose turnover [364].

However, in PDT, widely recognized as a highly effective precision therapy, the key challenge remains to refine it for use in hypoxic tumors. One approach to solving the problem of hypoxia may be the combination of PDT with hyperthermia. Li et al. demonstrated against hypoxic tumors the use of polymer vesicles that are capable of deeply penetrating the tumor and at the same time providing oxygen delivery after irradiation with light. Namely, after exposure to light, a thermal effect is induced, which can decompose hydrogen peroxide into oxygen, and then after irradiation at $660 \mathrm{~nm}$, the vesicles are quickly destabilized by splitting the copolymer with singlet oxygen under the influence of light irradiation, which allows the release of photoactive poly(amidoamine) dendrimer conjugating chlorin e6/cypate (CC-PAMAM) [365].

Moreover, Kurokawa et al. also showed that treatment with hyperthermia $\left(42{ }^{\circ} \mathrm{C}\right)$ can increase the production of mitochondrial reactive oxygen species (mitROS), thereby enhancing the effects of PDT in cancer cells. The mechanism of this phenomenon was most likely due to both the increase in the expression level of the heme carrier protein-1 (HCP-1) and the decrease in the level of the ABCG2 transporter by mitROS [206].

\section{Proposed Combinations That Are Currently Used in Multimodal Cancer Treatment}

Radiotherapy, chemotherapy, and surgical intervention are reliable options for treating cancer [366]. Currently, multi-module treatment is used quite commonly to treat cancer: 
chemotherapy and radiotherapy are used together very often. In addition, attempts are being made to enhance therapeutic effects by improving the mechanisms on which standard treatments are based. These attempts focus on aspects related to delivery of drugs, photosensitizers, or chemotherapeutic agents in order to minimize side effects and to act selectively. Therefore, drugs can be delivered using liposomes, and chemotherapeutics with a different spectrum of activity can be used to enhance therapeutic effects. In addition, research using gene therapy is being carried out, and new drug are being designed. New mechanisms have been developed to achieve better results without damaging healthy structures, which is why, for example, a radiation-based gamma knife or cyber knife are used.

\subsection{Radiotherapy}

Radiotherapy is an important part of cancer treatment, and its main goal is to deprive cancer cells of their proliferation potential. Radiation is a physical factor that stores energy in the cells of the tissues it passes through, and then this deposited energy can kill cancer cells or cause genetic changes that lead to cancer cell death [367]. The main mechanism of killing cells by high-energy radiation involves damaging their genetic material of DNA, thereby blocking their ability to further divide and proliferate $[367,368]$. The goal of improving radiation therapy is to maximize the radiation dose to cancer cells while, at the same time, minimizing the exposure of healthy cells that are adjacent to cancer cells or are exposed to radiation [367]. Radiotherapy is also used in conjunction with other treatments, such as surgery, chemotherapy, or immunotherapy.

Currently, brachytherapy and teleradiotherapy are commonly used. Brachytherapy involves treatment with the use of a radiation source that must be as close to the tumor as possible. The mechanism of brachytherapy is based on the use of radiation in direct contact with the tumor. However, when it comes to teleradiotherapy, the source of radiation is located at a certain distance from the tissue within the area of the cancer. In the context of radiotherapy, the so-called $5 \mathrm{R}$ principle that occurs during radiotherapy: redistribution, repopulation, reoxygenation, repair, and radiosensitivity is worth highlighting [369]. Radiation can be classified as ionizing radiation (e.g., $\mathrm{X}$ and gamma radiation) or particle radiation with electrons, protons, alpha particles, and neutrons. The biological mechanism of action depends on the type of radiation (e.g., relevance of linear transfer energy and cell damage). On the other hand, cancerous tissue parameters can provoke effects, such as the increase in sensitivity of cancer cells to ionizing radiation if the activity during the division of cancer cells is also greater. However, a higher level of differentiation makes cells less sensitive to radiation. The level of tumor oxygenation is also an important factor. When tumor is more hypoxic, the cancer cells are less sensitive to radiation (oxygen enhancement ratio is 2.5-3 times bigger for a well oxygenized tissue). In context of radiotherapy, there is a very interesting strategy to treat malignant eye tumors-protonotherapy. This technique uses Bragg's pick to deposit energy into the tumor, and the healthy tissue around the tumor is kept safe at the same time [370]. It was shown that proton radiation can inhibit the metastatic potential of primary cancer cells.

In the outcome of radiotherapy methods and mechanisms, temporary inhibition of tumor growth or growth retardation and tumor regression may take place. There are many factors that have to be considered, although these mechanisms can be influenced by the duration of the cell cycle, the size of the cell growth fraction or the rate of cell loss.

From the perspective of potential needs for combination treatment involving the use of radiotherapy, a few factors should be taken into consideration. Regarding the above-mentioned cell sensitivity to radiation (e.g., cell cycle, oxygen enhancement), the main need is to overcome radioresistance. For example, melanomas are quite resistant to radiation therapy due to their melanin accumulation (accumulation of pigment that acts as a radioprotector). Additionally, cancer cells that contain melanin are hypoxic and, therefore, more resistant to low LET radiation. A high level of cell differentiation also contributes to this resistance [371]. In the treatment of melanoma where melanin is present, 
its role is to scavenge free radicals. This mechanism allows putting this pigment in the radioprotector category. It protects melanin against the impact of ionizing radiation, for example X-radiation. What is worth emphasizing is that this pigment increases radiation resistance by inactivating free radicals that are formed during the course of radiation. A well-applied complementary treatment can increase melanoma sensitiveness to ROS.

The limitations of radiotherapy, such as insufficient tissue oxygenation can be overcome by using complementary therapies. One such technique is hyperthermia, which is usually a complementary method that involves heating the tumor in order to inhibit the proliferation of cancer cells, destroy them, or make them sensitive to various treatments, including radiation therapy. The combination of hyperthermia and radiotherapy shows a synergistic effect and enhances the killing effect on cancer cells, especially those in the $S$ phase of the cell cycle, which are usually resistant to radiation when applied alone [19]. The synergistic effect of heat and radiation is defined as the thermal enhancement ratio (TER), which defines the magnitude of thermal hypersensitivity to radiation as the survival fraction quotient after irradiation alone and in combination with hyperthermia [372]. The effects of hyperthermia include, but are not limited to, inhibition of the repair of radiation-induced DNA damage, thereby increasing the cytotoxic effect of radiotherapy [372]. Moreover, by reducing the metabolic activity of target cells, heat reduces the oxygen demand of the tumor and increases the oxygenation of the tumor tissue as well, making hyperthermia one of the most powerful radiosensitizers available [373].

Another approach to overcome the limitations of radiation therapy is to combine it with photodynamic therapy. Photodynamic therapy uses photosensitizers that are activated by visible or near-infrared light and transfer energy to molecular oxygen, thus generating reactive oxygen species [373]. Under certain conditions, some photosensitizers can act as radiosensitizers. Combining radiation therapy with photodynamic therapy, i.e., using ionizing radiation tissue penetration and photodynamic therapy can reduce penetration depth problems and can allow radiation dose reduction without decreased clinical efficacy [374], while minimizing damage to healthy tissues. Moreover, the combination of an appropriate photosensitizer with radiation therapy can lead to a significant increase in the cytotoxic and apoptotic death of cancer cells [375]. The combination of photodynamic therapy and radiation therapy, the primary goal of which is to kill cells through nuclear DNA damage, offers the possibility of synergism in killing cells, as photodynamic therapy does also induce several types of DNA damage [376]. In addition, photodynamic therapy does also improve the immune system's response by inducing inflammation and an immune response against cancer cells. Potential mechanisms of immune stimulation by photodynamic therapy include an acute inflammatory response that can enhance tumor antigen presentation to activate dendritic cells and to guide them to regional and peripheral lymph nodes, ultimately stimulating cytotoxic T lymphocytes and NK cells, accompanied by the formation of immune memory and growth suppression tumor in the future [255].

\subsection{Chemotherapy}

Chemotherapy is a very broad category of anti-cancer treatment. The induction of apoptosis and the inhibition of mitosis as well as the cell cycle disorder are caused by the use of chemotherapeutic agents. Cytostatic drugs can be grouped into alkylating agents, alkaloids, antibiotics, and antimetabolites. Inhibitor of tyrosine kinases are also very important novel drugs. They affect cell proliferation by targeting cellular DNA or RNA and metabolism with antimetabolites acting on purine or pyrimidine metabolic enzymes, while alkaloids act on the cytoskeleton and mitosis [377]. One of the main problem with chemotherapy is the effective, safe, and selective drug delivery. Chemotherapy is associated with the presence of side effects that include immediate signs of toxicity (effects can be seen on skin and hair, bone marrow and blood, gastrointestinal tract and kidneys, etc.) as well as late signs of chronic toxicity (drug resistance, carcinogenicity) [377]. In order to increase the effectiveness of chemotherapy and reduce side effects, a combination of various drugs with different mechanisms of action is used. Moreover, when several chemotherapeutic agents 
are used, drug resistance could be counteracted. Overall results of chemotherapy are also improved due to the use of combinations of drugs that do not have overlapping toxicities. Then, we can increase the dose of drugs in the tumor without fearing undesirable negative side effects of the therapy. This approach is used very often to reduce side effects since increasing the dose of only one drug can cause toxicity; therefore, it seems that combining drugs from different groups is less toxic and more effective due to the higher therapeutic dose applied. The same happens when we use drugs that have different mechanisms of action. In this case, cells that are insensitive to one drug are already sensitive to the other drug from this combination. Treating drug-resistant cancers is a significant problem not only in chemotherapy. This mechanism of drug resistance may be influenced by the fact that the chemotherapeutic agent alone is not able to reach the inside of the tumor directly. Still, other challenges face this approach as well, such as improving drug perfusion and increasing the accumulation of the therapeutic compound in the tumor. Hyperthermia, which causes changes in cells and their surroundings due to high temperature, seems to be a good complementary technique. In addition to direct ablation of cancer cells, elevated temperatures can also trigger drug release, especially for heat-sensitive carriers [378]. It is also known that raising the temperature from $37^{\circ} \mathrm{C}$ to $43^{\circ} \mathrm{C}$ such increases the permeability of the cell membrane, accelerating the absorption of nanoparticles, and it may increase the interaction of carriers with the cell membrane as well [379]. In particular, energydependent pathways, such as clathrin- and caveolae-mediated endocytosis are involved in increasing the permeability of the cell membrane at high temperature, thus increasing the internalization of drugs and carriers [378,379]. Hyperthermia also affects blood flow and, hence, changes the drug distribution. Certainly, the heat-induced change in blood flow in tumors differs from the one that occurs in regular tissues because the tumor vasculature is less able to dissipate heat and is more susceptible to damage during hyperthermia treatment. However, it is worth noting that mild heat increases blood flow in the tumor, allowing chemotherapy to have a greater effect on cancer cells [373]; thus, in some types of tumors, blood flow increases when heated to relatively low temperatures. On the other hand, higher temperatures $\left(43^{\circ} \mathrm{C}\right.$ or $\left.44^{\circ} \mathrm{C}\right)$ result in stronger and longer-lasting vascular closure [380].

In addition to allowing more efficient drug delivery, heat can also modify the cytotoxicity of many chemotherapeutic agents. In many cases, synergism can be seen as a continual change in the rate at which the drug kills cells as temperature increases. The cytotoxicity of most alkylating agents, platinum compounds, and also nitrosoureas increases linearly with the temperature increase, typically by thermal enhancement, including increased alkylation rate constants, increased drug absorption, and inhibition of repair of lethal or sublethal drug-induced damage [381].

Additionally, hyperthermia may increase the killing effect on tumor cells located at the hypoxic centers of tumors that are relatively resistant to chemotherapy due to poor drug delivery. In addition, some chemotherapy drugs also require oxygen to generate free radicals in order to induce tumor cytotoxicity. It is known that elevated temperatures can increase the rate of biochemical reactions, increasing cellular metabolism, which can result in an increased oxidative stress. The level of reactive oxygen species may increase after exposure to elevated temperatures, possibly due to dysfunction of the mitochondrial respiratory chain or by increased activity of the enzymes NADPH oxidase and xanthine oxidase [382].

\subsection{Surgical Intervention}

Surgery is one of the three most popular treatments for cancer today, and also the oldest one. It plays the most important role in the treatment of cancer. Its application ranges from the diagnosis of lesions, i.e., taking biopsies for diagnosis, through reducing the tumor mass, to radical treatment in order to completely excise the lesion together with a margin of healthy tissues. Complete tumor excision with cutting out a healthy tissue margin is the most effective form of treatment in the case of early stage neoplasms, 
especially when there are no metastases yet. Such achievement of a sufficiently negative margin during oncological surgery minimizes the risk of adverse treatment outcomes and recurrence of the disease [383]. In some cases, the unfavorable location of the tumor or the presence of disseminated metastases can make it impossible to remove the tumor. Hence, it is not always possible to obtain the necessary margin, in particular in case of surgery in the vascular system area, in case of other critical areas, and in case of tumor involvement in adjacent tissues. This problem applies to such neoplasms as hepatocellular carcinoma, pancreatic ductal adenocarcinoma (PDAC), neuroblastoma, or neuroendocrine tumors of the gastrointestinal tract. Involvement of a blood vessel can sometimes be resolved by surgical resection and reconstruction of the affected vessel, such as a vein or artery, but these procedures are associated with an increased risk for the patient, especially in the case of arteries [384,385].

In conclusion, failure to obtain adequate surgical margins increases both the surgical and oncological risk of poor prognosis, which is usually the case when tumors have invaded large blood vessels [385]. If it is impossible to remove the entire neoplastic lesion, the combination of surgery and radiation therapy is often used. Postoperative radiotherapy reduces the risk of cancer recurrence and also helps destroy any remaining cancer cells, especially when only the tumor was removed and only a small amount of regular tissue around it was removed, or a margin is left that is positive for cancer cells. Indications for postoperative radiotherapy include not only insufficient resection margin, but also uncertain radicality of resection, infiltration of tissue with diffuse cancer foci, and low tumor differentiation. Therefore, in most cases, only combinations of treatments such as surgery combined with radiation therapy are usually the only way to destroy cancer cells [373].

Returning to the issue of tumor areas that cannot be surgically excised due to the fact that their location is too close to inoperable vessel, there is one interesting complementary method: the use of local, mild hyperthermia. By applying uniform and gentle heating, we can destroy tumors that surround the vessels and, at the same time, protect these sensitive structures from damage [385]. It has been shown (on the example of pancreatic ductal adenocarcinoma) that an increase in temperature in the range of $41-46{ }^{\circ} \mathrm{C}$ leads to killing cancer cells, including the elimination of cancer stem cells, as well as changes in the proteomic profiles of cancer cells, with simultaneous protection of regular cells [385].

Another method that is complementary to surgery is photodynamic therapy, which is based on the complex cell killing phenomenon resulting from the interaction of a chemical compound (photosensitizer), light, and oxygen. Photodynamic therapy is recognized as a safe and effective method, and this is why it plays a unique role in the treatment of cancer with its targeting precision. It does not damage healthy structures surrounding the treated lesions, and it is applied in the treatment of cancerous tumors with limited access [386]. In systemic photodynamic therapy there is a wide distribution of photosensitizer, but there is also a higher potential for accumulation in cancerous tissues than in healthy tissues, and multi-site deep light, which can be performed intraoperatively in combination with standard or minimal surgical access [386]. Consequently, by using the preferential accumulation of photosensitizers in cancer cells with the appropriate selection of irradiation, it is possible to eliminate the remaining tumor fragments that cannot be surgically removed. Photodynamic therapy may be used in some cases before surgery as a neoadjuvant therapy to alleviate cancer.

In addition to destroying cancer cells, photodynamic therapy is closely related to the fluorescence phenomenon used in photodiagnostics to detect lesions. As noted, the optical properties of healthy and abnormal tissues in the ultraviolet and visible spectrum differ from each other. Due to endogenous chromophores, some tissues exhibit a characteristic fluorescence emission band that changes when the disease process occurs, changing these chromophore components [386]. Thus, using the appropriate wavelength, an image can be obtained that is used as the basis of autofluorescence photodiagnosis [386,387]. This method may be helpful in determining the optimal biopsy site for histological diagnosis. In 
addition to using endogenous chromophores, photosensitizers can be used as exogenous fluorophores to enhance fluorescence [386]. The use of such enhanced photodiagnostics is especially valuable in surgical operations where it can indicate residual neoplastic infiltration, which may be present at the margin of resection. In addition, it can be used in brain surgeries, in the removal of tumor remains that are invisible to the naked eye or with the use of microscopic surgical instruments [386,388].

\section{Hypoxia as a Treatment Imitation Factor}

The phenomenon of hypoxia is defined as the state of $\mathrm{O}_{2}$ partial pressure reduced below critical thresholds specific for particular tissue, or from a biochemical point of view as $\mathrm{O}_{2}$-restricted electron transport [389]. Low oxygen tension often occurs in cancer cells due to several mechanisms, e.g., poor angiogenesis and/or increased oxygen consumption, pathological vasculature, and anemia. Hypoxia is an oxygen tension in the range from $<0.01 \%$ (anoxia) to 5\%, and it can be chronic, acute, or cyclic, with different effects on cancer cells [390]. From a radiobiology perspective, hypoxic fraction (percentage of hypoxic volume inside the tumor) defined by $\mathrm{pO}_{2}<10 \mathrm{~mm} \mathrm{Hg}$ is crucial for the therapy response [391].

Hypoxia makes cancer cells more aggressive, it contributes to their resistance to all kinds of treatment. The amount of oxygen in a tumor depends on the tumor stage and size, and on the cell metabolism as well. Signaling pathways associated with tumor hypoxia is usually induced by HIF induced hypoxia factors. Overexpression of HIF- $1 \alpha$ and HIF- $2 \alpha$ causes an increase in angiogenesis, aggressiveness, and resistance to treatment [392]. Low levels of oxygen are usually found in tumors. It may be caused by impairment, improper structure of blood vessels. Hypoxia of tumors is a serious challenge in cancer therapy, and hypoxic tumors are often much more difficult to treat than the well-oxygenated tumors.

It was shown that that the occurrence of hypoxia vary independently on tumor size and type. This is definitely a factor that contributes to increased resistance to treatment. Tumor-building cancer stem cells (CSCs) are recognized as potential initiators of induction, progression, and increased metastatic capacity. In addition, cancer stem cells make the tumor much more heterogeneous, which definitely affects its resistance to any therapies that are aimed directly at tumor destruction. At this point, hypoxic niche could determine the phenomenon of hypoxia. Hypoxia itself is believed to be a factor that actually contributes to the phenotype of stem cells. In hypoxic niche, stem cells become carcinogenic cells and cause further metastasis. Hypoxic cells are much less susceptible to treatment, and due to the presence of a chaotic network of blood vessels within the tumor, the ability to accumulate chemotherapeutic agents is significantly reduced [393].

Due to tumor hypoxia, cancer therapy usually becomes less effective. Unfortunately, this situation leads to an increase in cancer spreading. Hypoxic cells are definitely more aggressive as compared to normoxic ones. Such as hypoxic cell are undernourished, and are well adjusted to harsh microenvironment which created hypoxic niche. One of examples of how different hypoxic environment can be acidic $\mathrm{pH}$ correlated with low $\mathrm{pO}_{2}$ [394]. When the tumor area is heated, such cells should be more susceptible to damage and death than cells that proliferate properly and with regular metabolism. It is worth emphasizing that if there is a necrosis around the tumor, shrinking of cancer cells can be observed in most cases. On the other hand, cancer stem cells can survive in such an environment and can be responsible for future cancer recurrence. Hyperthermia and the associated increase in temperature in the tumor region affect cancer cells. The mechanism of thermoregulation is becoming handicapped and there is no efficient heat dissipation due to the damage to blood vessels [393].

As we know, there is an area of low oxygenation within a tumor. This condition lowers treatment options as the cells are highly resistant to radiation. In order to counteract this phenomenon, the availability of oxygen within the tumor should be increased. Hyperthermia can be used for this purpose. It will increase blood flow through the blood vessels that entwine the tumor and supply it with nutrients, drugs, and oxygen. Increasing blood flow 
through the vessels should definitely improve the degree of oxygenation of the tumor itself and the surrounding tissues. Thanks to this approach, the state of hypoxia can be reduced, at least for a while, which will allow sensitizing cells to radiation in a given time window, and in the case of DNA damage, repair mechanisms will be weakened [395].

In general, hypoxic regions are poorly perfused, which has an influence on the drug accumulation potential. It is postulated that one of the reasons of hypoxic cells resistance is related to sublethal chemotherapeutic drug concentration. As a result, cancer cells gain abilities to remove drugs due to the presence of $A B C$ transporters, and become more resistant to treatment. When there is a hypoxia, regulation of ABCG2 expression increases, and this allows a survival of a larger fraction of cells since the photosensitizer accumulates less intensively in the tumor area. This makes photodynamic therapy less effective [364,396]. Additionally, cells in hypoxic fractions of tumors are very often in G0 phase in the cell cycle, which makes them more resistant to chemotherapeutic drugs designed e.g., to stop DNA synthesis. These issues can affect localization of a photosensitizer that can accumulate in a manner dependent on its distance from blood vessels. However, researchers are trying to target drugs to hypoxic regions with two mechanisms: (a) active targeting-when the drug has affinity for molecular targets, like GLUT-1, and (b) passive targeting-when the drug has a better potential to localize in hypoxic fraction due to e.g., $\mathrm{pH}$, lipophilicity, or size. Passive targeting in the time scale is a very interesting option for a photosensitizer-it was shown that a longer time interval between PS injection and illumination allows improving PS localization in poor perfused areas [21].

Cells susceptible to chemotherapy are mainly the types of cells that are characterized by a relatively fast rate of proliferation, which in turn distinguishes hypoxic cells that usually have a much slower degree of proliferation, which makes chemotherapeutic agents unable to act on slowly dividing cells. Drug resistance can occur as a result of stopping the cell cycle. Changing the state and lowering the rate of cell metabolism as well as increasing the rate of DNA replication also play an important role. Additionally, hypoxia may contribute to autophagy, which can cause both pro-apoptosis and survival of cancer cells. It has also been reported that the autophagy resulting from hypoxia is associated with the occurrence of drug resistance [397]. The autophagy process allows degrading damaged cell components, it is a kind of response before apoptosis that would occur due to the use of chemotherapeutic agents [398]. The use of, e.g., cisplatin allows for the stimulation of a defense response, as a result of which the autophagy process is initiated through the induction and regulation of AMPK and MTOR [399]. Hypoxia can also be caused by surgery in the area where the tumor was resected. Oncological surgery increases the ability of neoplastic cells to migrate and metastasize, and to relapse the tumor to the same place [400].

Research is currently underway to improve PDT where high levels of cancer hypoxia are involved. In PDT, hypoxia is clearly a serious problem, because the lack of oxygen in cancer cells leads to much less ROS production. To achieve an effective tumor response under hypoxic conditions, combination therapy would need to be optimized to promote some form of tumor reoxygenation [343]. The role of Hypoxia Inducible Factor's (HIF's) effect on tumor resistance is also significant. Low oxygen partial pressure can induce pleiotropic HIFs-related signaling cascade and regulate angiogenesis, apoptosis, metastasis, or cellular metabolism. After PDT, the hypoxia is very often observed inside the tumor, for a shorter or a longer period of time [21]. It needs to be highlighted that even very short hypoxic periods can provoke HIFs and enhanced angiogenesis. One of combination treatment strategies is the inhibition of VEGF after PDT. To summarize, in the context of photodynamic therapy, there are some photosensitizers that affect hypoxic cells. They selectively increase the sensitivity to radiation only in poorly oxygenated cells. It is also worth noticing that the destruction of the tumor with X-rays is often hampered by the existence of hypoxic cells that are very resistant to radiation and drugs. What is worth emphasizing in this context is that hypoxia in a tumor is often a local phenomenon. It is suggested that determination of the hypoxia area location in the tumor may allow the 
exposure of this area to a higher dose of radiation, which is to increase the therapeutic index [391].

The hypoxia makes cancer cells resistant to radiation, allows cancer cells to survive in a tumor's microenvironment with a very low degree of oxygenation. Thanks to hypoxia, cells have an increased potential to inhibit damage in genetic material. When cells are in a hypoxic state, post-translational modifications of histones and DNA methylation may occur [401]. As it is known, during radiotherapy there is direct and indirect damage to DNA, and if there is some compensation and no damage to the genetic material due to hypoxia, the radiotherapy is not effective. In addition, the resistance to oxidative stress increases in hypoxia, which makes radiotherapy ineffective. Reducing the degree of radiation sensitivity is associated mainly with HIF- $1 \alpha$, which seems to play a significant role in the degree of tumor sensitivity to radiotherapy [402].

In this case, the use of fractionated radiotherapy to effectively treat oxygenated external parts of the tumor is one of the available options. This approach leads to reoxygenation of previously hypoxic tumor cells, which are still viable, and at this point, radiation therapy can be combined with PDT in order to effectively treat previously hypoxic parts of the tumor [343]. As already mentioned, another option would be to combine PDT with hyperthermia, which has been shown to target the vasculature of the tumor, which can then initiate tumor angiogenesis, leading to reoxygenation of tumor tissue [403,404]. However, this solution should be studied carefully due to the fact that tumor angiogenesis can lead to tumor growth. Hypoxia definitely has a negative effect on cancer treatment and reduces the effectiveness of all methods, and it is associated with a faster development of the disease. Undoubtedly, the impact of the hypoxic tumor environment on the effectiveness of combination therapy including PDT is also significant, and this should be taken into consideration when assessing different treatment options.

\section{Conclusions}

Due to cancer heterogeneity and the complexity of the disease, the proposed treatment procedure should be individualized. The type of cancer, specific biomarkers, stage of disease, and coexisting conditions are just some elements of a long list of factors that should be taken into consideration when planning the treatment. Choosing the therapy always involves finding a balance between fighting with cancer cells and minimizing side effects. Combination treatment is one of the most promising ways to reduce side effects, to focus on destroying cancer cells, and to stimulate anti-cancer immunity (Figure 2). In this context, photodynamic therapy and hyperthermia treatments appear as perfect candidates for complementary therapies. First, both of them can be site-specific and directly kill cancer cells by inducing apoptosis, necrosis, and different types of cell death. Second, both methods can have a significant influence on tumor perfusion and vessel structure in a dosedependent manner in order to achieve: (a) vessels pruning, flow shut down, and severe hypoxia (for heat ablation and vascular targeted PDT); (b) stimulation of blood perfusion that can lead to good tissue perfusion and more effective drug accumulation inside the tumor (mild hyperthermia, cellular targeted PDT). Finally, hyperthermia and PDT can not only induce a strong immune response locally inside the tumor (inflammation), but can also trigger a systemic response against cancer. It was shown that PDT and hyperthermia alone can be effective against particular types of cancer, just like chemotherapy, immunotherapy, radiotherapy, and surgery. However, based on current statistics, 1 of 3 cancer patients is uncurable. Scientists are constantly developing new treatment options, but maybe more attention should be paid to bringing out a new quality from what we already know? Clinical experiences indicate that combination treatment is more than just a sum of basic therapies; the optimized multi-module treatment creates a new quality to help find a cure. The implementation of this type of treatment requires, above all, a qualified group of people and specialized equipment. For these therapies to be effective, it is good to target the therapeutic window, thanks to which the results will be more effective. Most importantly, to be able to start such treatment at all, it is necessary to thoroughly understand not only 
the mechanism of action of the therapy, but also the kinetics of the action of nanodrugs. All of this will translate into higher treatment success.
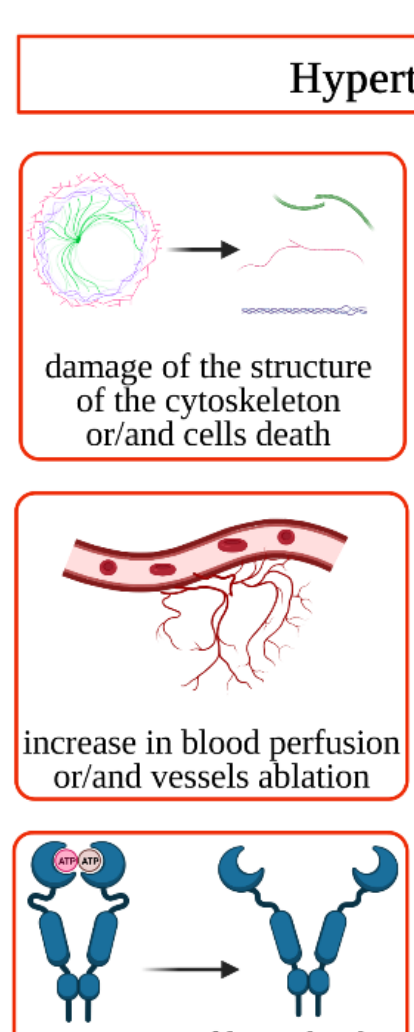

activation of heat shock proteins and stimulation of the immune system
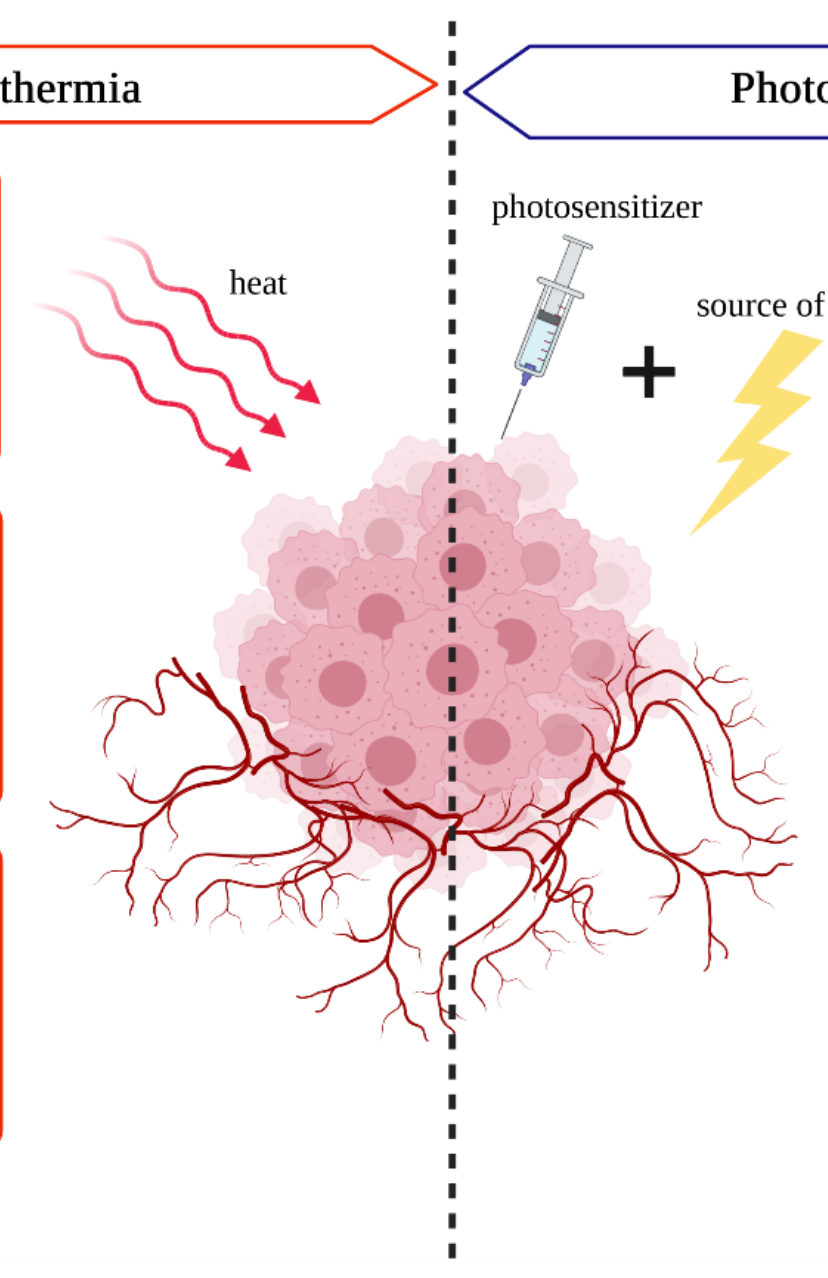

\section{Photodynamic therapy}

ource of light
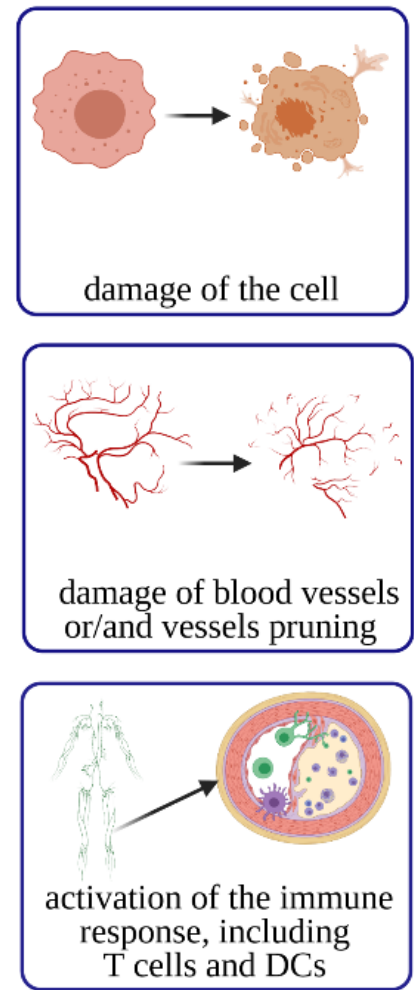

Figure 2. Effects of hyperthermia and PDT at the cellular, vascular, and immune levels.

Author Contributions: A.B., O.W.-C., A.A.M. wrote the manuscript; A.A.M. performed the search at ClinicalTrials.gov; M.K.-S. planned and corrected the manuscript. All authors have read and agreed to the published version of the manuscript.

Funding: This research was funded by the National Science Center (Poland), grant number UMO2018/29/B/NZ5/02954.

Institutional Review Board Statement: Not applicable.

Informed Consent Statement: Not applicable.

Data Availability Statement: Not applicable.

Acknowledgments: Martyna Krzykawska-Serda would like to thank the National Science Center (Poland) for their support (grant number UMO-2018/29/B/NZ5/02954). Aleksandra Bienia would like to thank the Jagiellonian University. The research was supported by a grant from the Priority Research Area POB BioS under the Strategic Programme Excellence Initiative at the Jagiellonian University. All figures were created with BioRender.com (Confirmation of Publication and Licensing Rights-25 June 2021).

Conflicts of Interest: No conflict of interest to declare. 


\section{References}

1. Bray, F.; Me, J.F.; Soerjomataram, I.; Siegel, R.L.; Torre, L.A.; Jemal, A. Global cancer statistics 2018: GLOBOCAN estimates of incidence and mortality worldwide for 36 cancers in 185 countries. CA A Cancer J. Clin. 2018, 68, 394-424. [CrossRef]

2. Siegel, R.L.; Miller, K.D.; Jemal, A. Cancer statistics, 2020. CA Cancer J. Clin. 2020, 70, 7-30. [CrossRef]

3. Nicholas, C.; Lesinski, G.B. Immunomodulatory cytokines as therapeutic agents for melanoma. Immunomodulatory 2013, 3, 673-690. [CrossRef]

4. Mokhtari, R.B.; Homayouni, T.S.; Baluch, N.; Morgatskaya, E.; Kumar, S.; Das, B.; Yeger, H. Combination therapy in combating cancer. Oncotarget 2017, 8, 38022-38043. [CrossRef]

5. Wang, T.; Narayanaswamy, R.; Ren, H.; Torchilin, V.P. Combination therapy targeting both cancer stem-like cells and bulk tumor cells for improved efficacy of breast cancer treatment. Cancer Biol. Ther. 2016, 17, 698-707. [CrossRef]

6. Yuan, S.; Wang, F.; Chen, G.; Zhang, H.; Feng, L.; Wang, L.; Colman, H.; Keating, M.J.; Li, X.; Xu, R.-H.; et al. Effective Elimination of Cancer Stem Cells By a Novel Drug Combination Strategy. STEM CELLS 2012, 31, 23-34. [CrossRef] [PubMed]

7. Delbaldo, C.; Michiels, S.; Syz, N.; Soria, J.-C.; Le Chevalier, T.; Pignon, J.-P. Benefits of Adding a Drug to a Single-Agent or a 2-Agent Chemotherapy Regimen in Advanced Non-Small-Cell Lung Cancer. JAMA 2004, 292, 470-484. [CrossRef] [PubMed]

8. García-Román, J.; Zentella-Dehesa, A. Vascular permeability changes involved in tumor metastasis. Cancer Lett. 2013, 335, 259-269. [CrossRef]

9. Chen, J.; Weihs, D.; Vermolen, F.J. Computational modeling of therapy on pancreatic cancer in its early stages. Biomech. Model. Mechanobiol. 2019, 19, 427-444. [CrossRef]

10. Srivani, G.; Behera, S.K.; Dariya, B.; Chalikonda, G.; Alam, A.; Nagaraju, G.P. HIF-1 $\alpha$ and RKIP: A computational approach for pancreatic cancer therapy. Mol. Cell. Biochem. 2020, 472, 95-103. [CrossRef] [PubMed]

11. Lala, M.; Li, T.R.; de Alwis, D.P.; Sinha, V.; Mayawala, K.; Yamamoto, N.; Siu, L.L.; Chartash, E.; Aboshady, H.; Jain, L. A six-weekly dosing schedule for pembrolizumab in patients with cancer based on evaluation using modelling and simulation. Eur. J. Cancer 2020, 131, 68-75. [CrossRef]

12. Yang, Y.-C.; Chiang, C.-S. Challenges of Using High-Dose Fractionation Radiotherapy in Combination Therapy. Front. Oncol. 2016, 6, 165. [CrossRef]

13. Zheng, X.; Chen, Y.; Zheng, D.; Xiao, Y.; Chen, J.; Pan, J.; Chen, W. Diffusion kurtosis imaging and tumour microstructure for monitoring response to radiotherapy in human nasopharyngeal carcinoma xenografts. Jpn. J. Clin. Oncol. 2020, 50, 548-555. [CrossRef]

14. Bhuyan, B.K. Kineticsof Cell Kill by Hyperthermia. Cancer Res. 1979, 39, 2277-2284. [PubMed]

15. Overgaard, J.; Overgaard, J. The current and potential role of hyperthermia in radiotherapy. Int. J. Radiat. Oncol. 1989, 16, 535-549. [CrossRef]

16. Cheng, Y.; Weng, S.; Yu, L.; Zhu, N.; Yang, M.; Yuan, Y. The Role of Hyperthermia in the Multidisciplinary Treatment of Malignant Tumors. Integr. Cancer Ther. 2019, 18. [CrossRef]

17. Pritchard, J.R.; Lauffenburger, D.A.; Hemann, M.T. Understanding resistance to combination chemotherapy. Drug Resist. Updat. 2012, 15, 249-257. [CrossRef] [PubMed]

18. Jones, E.L.; Prosnitz, L.R.; Dewhirst, M.W.; Marcom, P.K.; Hardenbergh, P.H.; Marks, L.B.; Brizel, D.; Vujaskovic, Z. Thermochemoradiotherapy Improves Oxygenation in Locally Advanced Breast Cancer. Clin. Cancer Res. 2004, 10, $4287-4293$. [CrossRef] [PubMed]

19. Behrouzkia, Z.; Joveini, Z.; Keshavarzi, B.; Eyvazzadeh, N.; Aghdam, R.Z. Hyperthermia: How Can It Be Used? Oman Med. J. 2016, 31, 89-97. [CrossRef] [PubMed]

20. Dasari, S.; Tchounwou, P.B. Cisplatin in cancer therapy: Molecular mechanisms of action. Eur. J. Pharmacol. 2014, 740, 364-378. [CrossRef]

21. Krzykawska-Serda, M.; Dabrowski, J.M.; Arnaut, L.G.; Szczygieł, M.; Urbanska, K.; Stochel, G.; Elas, M. The role of strong hypoxia in tumors after treatment in the outcome of bacteriochlorin-based photodynamic therapy. Free. Radic. Biol. Med. 2014, 73, 239-251. [CrossRef] [PubMed]

22. Arnaut, L.G.; Pereira, M.M.; Dabrowski, J.; Silva, E.F.F.; Schaberle, F.; Abreu, A.R.; Rocha, L.B.; Barsan, M.M.; Urbanska, K.; Stochel, G.; et al. Photodynamic Therapy Efficacy Enhanced by Dynamics: The Role of Charge Transfer and Photostability in the Selection of Photosensitizers. Chem. A Eur. J. 2014, 20, 5346-5357. [CrossRef] [PubMed]

23. Peters, S.; De Ruysscher, D. NI Volumab CO Mbination with Standard First-line Chemotherapy and Radiotherapy in Locally Advanced Stage IIIA/B Non-Small Cell Lung Carcinoma (NICOLAS). European Thoracic Oncology Platform 2015. Available online: https:/ / clinicaltrials.gov/ct2/show / NCT02434081 (accessed on 26 April 2021).

24. Peters, S.; Felip, E.; Dafni, U.; Belka, C.; Guckenberger, M.; Irigoyen, A.; Nadal, E.; Becker, A.; Vees, H.; Pless, M.; et al. Safety evaluation of nivolumab added concurrently to radiotherapy in a standard first line chemo-radiotherapy regimen in stage III non-small cell lung cancer-The ETOP NICOLAS trial. Lung Cancer 2019, 133, 83-87. [CrossRef]

25. Peters, S.; Felip, E.; Dafni, U.; Tufman, A.; Guckenberger, M.; Álvarez, R.; Nadal, E.; Becker, A.; Vees, H.; Pless, M.; et al. Progression-Free and Overall Survival for Concurrent Nivolumab with Standard Concurrent Chemoradiotherapy in Locally Advanced Stage IIIA-B NSCLC: Results From the European Thoracic Oncology Platform NICOLAS Phase II Trial (European Thoracic Oncology Platform 6-14). J. Thorac. Oncol. 2021, 16, 278-288. [CrossRef] 
26. Provencio, M. No TitleLocally Advanced Trial of Tri-weekly Metronomic Oral Vinorelbine and Cisplatin as Induc-tion Therapy and Subsequent Concomitance with Radiation Therapy in Patients with Unresectable Non Small Cell Lung Cancer (NSCLC) (NORA). Spanish Lung Cancer Group; 2016. Available online: https://clinicaltrials.gov/ct2/show / NCT02709720 (accessed on 26 April 2021).

27. Provencio, M.; Majem, M.; Guirado, M.; Massuti, B.; Peñas, R.D.L.; Ortega, A.L.; Dómine, M.; Marsé, R.; Sala, M.; Paredes, A.; et al. Phase II clinical trial with metronomic oral vinorelbine and tri-weekly cisplatin as induction therapy, subsequently concomitant with radiotherapy (RT) in patients with locally advanced, unresectable, non-small cell lung cancer (NSCLC). Analysis of survival and value of ctDNA for patient selection. Lung Cancer 2021, 153, 25-34. [CrossRef]

28. Keam, B. Pembrolizumab and Paclitaxel in Refractory Small Cell Lung Cancer (MISP-MK3475). Seoul National University Hospital; 2015. Available online: https:/ / clinicaltrials.gov/ct2/show/NCT02551432 (accessed on 26 April 2021).

29. Kim, Y.; Keam, B.; Ock, C.-Y.; Song, S.; Kim, M.; Kim, S.H.; Kim, K.H.; Kim, J.-S.; Kim, T.M.; Kim, D.-W.; et al. A phase II study of pembrolizumab and paclitaxel in refractory extensive disease small cell lung cancer. J. Clin. Oncol. 2018, 36, 8575. [CrossRef]

30. Kim, Y.-J.; Keam, B.; Ock, C.-Y.; Song, S.; Kim, M.; Kim, S.H.; Kim, K.H.; Kim, J.-S.; Kim, T.M.; Kim, D.-W.; et al. A phase II study of pembrolizumab and paclitaxel in patients with relapsed or refractory small-cell lung cancer. Lung Cancer 2019, 136, 122-128. [CrossRef]

31. Reck, M. A Study Comparing SB8 and Avastin ${ }^{\circledR}$ in Patients with Advanced Non-squamous Non-small Cell Lung Cancer. Samsung Bioepis Co., Ltd.; 2016. Available online: https:/ / clinicaltrials.gov/ct2/show /NCT02754882 (accessed on 26 April 2021).

32. Reck, M.; Luft, A.; Bondarenko, I.; Shevnia, S.; Trukhin, D.; Kovalenko, N.V.; Vacharadze, K.; Andrea, F.; Hontsa, A.; Choi, J.; et al. A phase III, randomized, double-blind, multicenter study to compare the efficacy, safety, pharmacokinetics, and immunogenicity between SB8 (proposed bevacizumab biosimilar) and reference bevacizumab in patients with metastatic or recurrent nonsquamous non-small cell lung cancer. Lung Cancer 2020, 146, 12-18. [CrossRef]

33. Shaw, A. Nivolumab in Combination with Chemotherapy, or Nivolumab in Combination with Ipilimumab, in Advanced EGFR-Mutant or ALK-Rearranged NSCLC. Massachusetts General Hospital; 2017. Available online: https: / clinicaltrials.gov / ct2/show/NCT03256136 (accessed on 26 April 2021).

34. Owonikoko, T.K. Tremelimumab and Durvalumab with or without Radiation Therapy in Patients with Relapsed Small Cell Lung Cancer. Emory University; 2016. Available online: https:/ / clinicaltrials.gov/ct2/show /NCT02701400 (accessed on 26 April 2021).

35. Owonikoko, T.K.; Higgins, K.A.; Chen, Z.; Zhang, C.; Pillai, R.N.; Steuer, C.E.; Saba, N.F.; Pakkala, S.; Shin, D.M.; Zhang, G.; et al. A randomized phase II study of tremelimumab and durvalumab with or without radiation for patients with relapsed small cell lung cancer (SCLC). J. Clin. Oncol. 2019,37, 8515. [CrossRef]

36. Gandhi, L. Phase 1/2 Study of Ensartinib and Durvalumab, in ALK-Rearranged Non-Small Cell Lung Cancer. Ludwig Institute for Cancer Research; 2016. Available online: https:/ / clinicaltrials.gov/ct2/show / NCT02898116 (accessed on 26 April 2021).

37. Combination of Cryosurgery and NK Immunotherapy for Advanced Non-Small Cell Lung Cancer; Fuda Cancer Hospital: Guangzhou, China, 2016. Available online: https:/ / clinicaltrials.gov/ct2/show/NCT02843815 (accessed on 26 April 2021).

38. Lin, M.; Liang, S.-Z.; Wang, X.-H.; Liang, Y.-Q.; Zhang, M.-J.; Niu, L.-Z.; Chen, J.-B.; Li, H.-B.; Xu, K.-C. Clinical efficacy of percutaneous cryoablation combined with allogenic NK cell immunotherapy for advanced non-small cell lung cancer. Immunol. Res. 2017, 65, 880-887. [CrossRef] [PubMed]

39. Liu, L. Cryotherapy Combine Icotinib for Advanced NSCLC Treatment; Fuda Cancer Hospital: Guangzhou, China, 2016. Available online: https: / / clinicaltrials.gov/ct2/show / NCT02744664 (accessed on 26 April 2021).

40. A Study of Atezolizumab in Combination with Carboplatin Plus (+) Paclitaxel with or without Bevacizumab Compared with Carboplatin + Paclitaxel + Bevacizumab in Participants with Stage IV Non-Squamous Non-Small Cell Lung Cancer (NSCLC) (IMpower150). Hoffmann-La Roche; 2015. Available online: https:/ / clinicaltrials.gov/ct2/show / NCT02366143 (accessed on 26 April 2021).

41. Reck, M.; Mok, T.; Nishio, M.; Jotte, R.M.; Cappuzzo, F.; Orlandi, F.; Stroyakovskiy, D.; Nogami, N.; Rodríguez-Abreu, D.; Moro-Sibilot, D.; et al. Atezolizumab plus bevacizumab and chemotherapy in non-small-cell lung cancer (IMpower150): Key subgroup analyses of patients with EGFR mutations or baseline liver metastases in a randomised, open-label phase 3 trial. Lancet Respir. Med. 2019, 7, 387-401. [CrossRef]

42. Reck, M.; Wehler, T.; Orlandi, F.; Nogami, N.; Barone, C.; Moro-Sibilot, D.; Shtivelband, M.; Larriba, J.L.G.; Rothenstein, J.; Früh, M.; et al. Safety and Patient-Reported Outcomes of Atezolizumab Plus Chemotherapy with or without Bevacizumab Versus Bevacizumab Plus Chemotherapy in Non-Small-Cell Lung Cancer. J. Clin. Oncol. 2020, 38, 2530-2542. [CrossRef]

43. Reck, M.; Shankar, G.; Lee, A.; Coleman, S.; McCleland, M.; Papadimitrakopoulou, V.A.; Socinski, M.A.; Sandler, A. Atezolizumab in combination with bevacizumab, paclitaxel and carboplatin for the first-line treatment of patients with metastatic non-squamous non-small cell lung cancer, including patients with EGFR mutations. Expert Rev. Respir. Med. 2019, 14, 125-136. [CrossRef] [PubMed]

44. Socinski, M.A.; Jotte, R.M.; Cappuzzo, F.; Orlandi, F.; Stroyakovskiy, D.; Nogami, N.; Rodríguez-Abreu, D.; Moro-Sibilot, D.; Thomas, C.A.; Barlesi, F.; et al. Atezolizumab for First-Line Treatment of Metastatic Nonsquamous NSCLC. N. Engl. J. Med. 2018, 378, 2288-2301. [CrossRef]

45. Dinutuximab and Irinotecan Versus Irinotecan to Treat Subjects with Relapsed or Refractory Small Cell Lung Cancer. United Therapeutics; 2017. Available online: https:/ / clinicaltrials.gov/ct2/show / NCT03098030 (accessed on 26 April 2021). 
46. Edelman, M.J.; Juan, O.; Navarro, A.; Golden, G.; Borg, E.; Saunders, A.V. A two-part, open-label, randomized, phase 2/3 study of dinutuximab and irinotecan versus irinotecan for second-line treatment of subjects with relapsed or refractory small cell lung cancer. J. Clin. Oncol. 2018, 36, TPS8588. [CrossRef]

47. Ghebeh, H.; Al-Tweigeri, T. Study of Safety and Efficacy of Durvalumab in Combination with Paclitaxel in Metastatic Triple Negative Breast Cancer Patients. King Faisal Specialist Hospital \& Research Center; 2015. Available online: https://clinicaltrials. gov/ct2/show / NCT02628132 (accessed on 26 April 2021).

48. Loibl, S. Addition of PD-L1 Antibody MEDI4736 to a Taxane-anthracycline Chemotherapy in Triple Negative Breast Cancer (GeparNuevo). German Breast Group; 2016. Available online: https:/ / clinicaltrials.gov/ct2/show / NCT02685059 (accessed on 26 April 2021).

49. Loibl, S.; Untch, M.; Burchardi, N.; Huober, J.; Sinn, B.; Blohmer, J.-U.; Grischke, E.-M.; Furlanetto, J.; Tesch, H.; Hanusch, C.; et al. A randomised phase II study investigating durvalumab in addition to an anthracycline taxane-based neoadjuvant therapy in early triple-negative breast cancer: Clinical results and biomarker analysis of GeparNuevo study. Ann. Oncol. 2019, 30, 1279-1288. [CrossRef] [PubMed]

50. Cortes, J. PQR309 and Eribulin in Metastatic HER2 Negative and Triple-negative Breast Cancer (PIQHASSO). PIQUR Therapeutics AG; 2016. Available online: https://clinicaltrials.gov/ct2/show/NCT02723877 (accessed on 26 April 2021).

51. López-Miranda, E.; Gávila, J.; Pernas, S.; Saura, C.; Oliveira, M.; Serra, V.; Schmid, P.; Lord, S.; Paez, D.; Perez, J.; et al. Abstract OT1-01-06: PIQHASSO: Open label, non-randomized, multicenter phase 1/2b study investigating safety and efficacy of PQR309 and eribulin combination in patients (pts) with locally advanced (LA) or metastatic HER2 (-) and triple-negative breast cancer (TNBC) (study PQR309-007). Cancer Res. 2017, 77, OT1-01. [CrossRef]

52. Wang, K. TCH Versus EC-TH as Neoadjuvant Treatment for HER2-Positive Breast Cancer (neoCARH). Guangdong Provincial People's Hospital; 2017. Available online: https:/ / clinicaltrials.gov/ct2/show/NCT03140553 (accessed on 26 April 2021).

53. Li, W.; Zhu, T.; Hu, M.; Yang, M.; Ji, F.; Gao, H.F.; Yang, C.Q.; Zhang, L.L.; Cheng, M.Y.; Xu, F.P.; et al. Comparison of the efficacy and safety of the EC-T (epirubicin/cyclophosphamide followed by docetaxel) and TCb (docetaxel/carboplatin) neoadjuvant regimens in early TOP2A-normal stage II-III breast cancer. Neoplasma 2021, 67, 1409-1415. [CrossRef]

54. Tredan, O. Evaluation of Pembrolizumab in Lymphopenic Metastatic Breast Cancer Patients Treated with Metronomic Cyclophosphamide (CHEMOIMMUNE). Centre Leon Berard; 2017. Available online: https://clinicaltrials.gov/ct2/show/NCT03139851 (accessed on 26 April 2021).

55. Liu, G. Combination of Cryosurgery and NK Immunotherapy for Advanced Breast Cancer; Fuda Cancer Hospital: Guangzhou, China, 2016. Available online: https:/ / clinicaltrials.gov/ct2/show /NCT02844335 (accessed on 26 April 2021).

56. Cortés, J. T-DM1 and Non-pegylated Liposomal Doxorubicin in HER2-positive Metastatic Breast Cancer. MedSIR; 2015. Available online: https:/ / clinicaltrials.gov/ct2/show / NCT02562378 (accessed on 26 April 2021).

57. López-Miranda, E.; Pérez-García, J.M.; Di Cosimo, S.; Brain, E.; Ravnik, M.; Escrivá-de-Romaní, S.; Vidal, M.; Gligorov, J.; Borštnar, S.; Calabuig, L.; et al. Trastuzumab Emtansine Plus Non-Pegylated Liposomal Doxorubicin in HER2-Positive Metastatic Breast Cancer (Thelma): A Single-Arm, Multicenter, Phase Ib Trial. Cancers 2020, 12, 3509. [CrossRef]

58. López-Miranda, E.; Brain, E.; Saura, C.; Gligorov, J.; Dubot, C.; Dieras, V.; Suter, T.; Aguirre, E.; Perez-García, J.; Llombart, A.; et al. Abstract OT1-02-03: Phase I multicenter clinical trial evaluating the combination of trastuzumab emtansine (T-DM1) and non-pegylated liposomal doxorubicin (NPLD) in HER2-positive metastatic breast cancer (MBC) (MEDOPP038 study). Cancer Res. 2017, 77, OT1-02. [CrossRef]

59. Kukreja, A. Safety Study of Pertuzumab (in Combination with Trastuzumab and Docetaxel) in Indian Participants with Breast Cancer. Hoffmann-La Roche; 2015. Available online: https://clinicaltrials.gov/ct2/show/NCT02445586 (accessed on 26 April 2021).

60. Tiersten, A. Durvalumab and Eribulin in Her2-Negative Metastatic Breast Cancer and Recurrent Ovarian Cancer. 2018. Available online: https: / / clinicaltrials.gov/ct2/show/NCT03430518 (accessed on 26 April 2021).

61. Landry, C.A.; Guziel, J.M.; Ru, M.; Shapiro, C.L.; Fasano, J.; Bhardwaj, A.S.; Irie, H.; Bhardwaj, N.; Tiersten, A. A phase Ib study evaluating the safety and tolerability of durvalumab in combination with eribulin in patients with HER2-negative metastatic breast cancer and recurrent ovarian cancer. J. Clin. Oncol. 2018, 36, TPS3116. [CrossRef]

62. Phase IIIb Study to Evaluate the Safety and Tolerability of Herceptin SC with Perjeta and Docetaxel in Patients with HER2-positive Advanced Breast Cancer. Hoffmann-La Roche; 2015. Available online: https://clinicaltrials.gov/ct2/show/NCT02402712 (accessed on 26 April 2021).

63. Kuemmel, S.; Tondini, C.A.; Abraham, J.; Nowecki, Z.; Itrych, B.; Hitre, E.; Karaszewska, B.; Juárez-Ramiro, A.; Morales-Vásquez, F.; Pérez-García, J.M.; et al. Subcutaneous trastuzumab with pertuzumab and docetaxel in HER2-positive metastatic breast cancer: Final analysis of MetaPHER, a phase IIIb single-arm safety study. Breast Cancer Res. Treat. 2021, 187, 467-476. [CrossRef]

64. Dimery, I. A Multi-Center Study of Ibrutinib in Combination with MEDI4736 in Subjects with Relapsed or Refractory Solid Tumors. Pharmacyclics LLC; 2015. Available online: https:/ / linicaltrials.gov/ct2/show/NCT02403271 (accessed on 26 April 2021).

65. Hong, D.; Rasco, D.; Veeder, M.; Luke, J.J.; Chandler, J.; Balmanoukian, A.; George, T.; Munster, P.; Berlin, J.D.; Gutierrez, M.; et al. A Phase $1 b / 2$ Study of the Bruton Tyrosine Kinase Inhibitor Ibrutinib and the PD-L1 Inhibitor Durvalumab in Patients with Pretreated Solid Tumors. Oncology 2019, 97, 102-111. [CrossRef] [PubMed] 
66. Palbociclib in Combination with Letrozole As Treatment of Post-Menopausal Women with HR+, HER2- Advanced Breast Cancer. Pfizer; 2016. Available online: https:/ / clinicaltrials.gov/ct2/show/NCT02679755 (accessed on 26 April 2021).

67. Campone, M. S 81694 Plus Paclitaxel in Metastatic Breast Cancer. Institut de Recherches Internationales Servier; 2017. Available online: https:/ / clinicaltrials.gov/ct2/show/NCT03411161 (accessed on 26 April 2021).

68. Cardona, M. Nintedanib + Letrozole in Postmenopausal Women with Breast Cancer: Clinical Trial Safety and Pharmacodynamics. Centro Nacional de Investigaciones Oncologicas CARLOS III; 2015. Available online: https:/ / clinicaltrials.gov/ct2/show / NCT0 2619162 (accessed on 26 April 2021).

69. Quintela-Fandino, M.; Apala, J.V.; Malon, D.; Mouron, S.; Hornedo, J.; Gonzalez-Cortijo, L.; Colomer, R.; Guerra, J. Nintedanib plus letrozole in early breast cancer: A phase $0 / \mathrm{I}$ pharmacodynamic, pharmacokinetic, and safety clinical trial of combined FGFR1 and aromatase inhibition. Breast Cancer Res. 2019, 21, 69. [CrossRef] [PubMed]

70. Prat, A.; Gavilá, J. Neadjuvant Multiagent Chemotherapy or Letrozole Plus Ribociclib in Luminal B/HER2-negative Breast Cancer. (CORALLEEN). SOLTI Breast Cancer Research Group; 2017. Available online: https:/ / clinicaltrials.gov/ct2/show / NCT03248427 (accessed on 26 April 2021).

71. Prat, A.; Saura, C.; Pascual, T.; Hernando, C.; Munoz, M.; Pare, L.; Farré, B.G.; Fernández, P.L.; Galván, P.; Chic, N.; et al. Ribociclib plus letrozole versus chemotherapy for postmenopausal women with hormone receptor-positive, HER2-negative, luminal B breast cancer (CORALLEEN): An open-label, multicentre, randomised, phase 2 trial. Lancet Oncol. 2020, 21, 33-43. [CrossRef]

72. Conte, P. Neoadjuvant Chemo-endocrine Therapy and Immunotherapy for Pre-menopausal Luminal B Breast Cancer Patients (GIADA). Istituto Oncologico Veneto IRCCS; 2018. Available online: https:/ / clinicaltrials.gov/ct2/show / NCT04659551 (accessed on 26 April 2021).

73. Ueno, N. Trial of Ra-223 Dichloride in Combination with Hormonal Therapy and Denosumab in the Treatment of Patients with Hormone-Positive Bone-Dominant Metastatic Breast Cancer. M.D. Anderson Cancer Center; 2015. Available online: https: / / www.clinicaltrials.gov/ct2/show / NCT02366130 (accessed on 26 April 2021).

74. Ueno, N.T.; Tahara, R.K.; Fujii, T.; Reuben, J.M.; Gao, H.; Saigal, B.; Lucci, A.; Iwase, T.; Ibrahim, N.K.; Damodaran, S.; et al. Phase II study of Radium-223 dichloride combined with hormonal therapy for hormone receptor-positive, bone-dominant metastatic breast cancer. Cancer Med. 2019, 9, 1025-1032. [CrossRef]

75. Chang, J.C.N. TAK-228 Plus Tamoxifen in Patients with ER-Positive, HER2-negative Breast Cancer (ANETT). 2016. Available online: https: / clinicaltrials.gov/ct2/show / NCT02988986 (accessed on 26 April 2021).

76. Koca, E.; Niravath, P.A.; Ensor, J.; Patel, T.A.; Li, X.; Hemati, P.; Wong, H.; Qian, W.; Boone, T.; Zhao, J.; et al. Open label, phase II trial of neoadjuvant TAK-228 plus tamoxifen in patients with estrogen receptor (ER)-positive, human epidermal growth factor receptor type 2 (HER2)-negative breast cancer-ANETT. J. Clin. Oncol. 2019, 37, 584. [CrossRef]

77. Koca, E.; Niravath, P.A.; Ensor, J.; Patel, T.A.; Li, X.; Hemati, P.; Wong, H.; Qian, W.; Boone, T.; Zhao, J.; et al. ANETT: PhAse II trial of NEoadjuvant TAK-228 plus Tamoxifen in patients with hormone receptor-positive breast cancer. Breast Cancer Res. Treat. 2021, 1-7. [CrossRef]

78. A Study to Evaluate the Efficacy and Safety of Pertuzumab + Trastuzumab + Docetaxel Versus Placebo + Trastuzumab + Docetaxel in Previously Untreated Human Epidermal Growth Factor Receptor 2 (HER2)-Positive Metastatic Breast Cancer (PUFFIN). Hoffmannla Roche; 2016. Available online: https:/ clinicaltrials.gov/ct2/show/NCT02896855 (accessed on 26 April 2021).

79. Xu, B.; Li, W.; Zhang, Q.; Shao, Z.; Li, Q.; Wang, X.; Li, H.; Sun, T.; Yin, Y.; Zheng, H.; et al. Pertuzumab, trastuzumab, and docetaxel for Chinese patients with previously untreated HER2-positive locally recurrent or metastatic breast cancer (PUFFIN): A phase III, randomized, double-blind, placebo-controlled study. Breast Cancer Res. Treat. 2020, 182, 689-697. [CrossRef] [PubMed]

80. Posadas, E.M. Study of TRC105 with Abiraterone and with Enzalutamide in Prostate Cancer Patients Progressing on Therapy. Cedars-Sinai Medical Center; 2018. Available online: https://clinicaltrials.gov/ct2/show/NCT03418324 (accessed on 26 April 2021).

81. Tagawa, S. Neoadjuvant J591 Treatment for Prostate Cancer. Weill Medical College of Cornell University; 2016. Available online: https: / clinicaltrials.gov/ct2/show / NCT02693860 (accessed on 26 April 2021).

82. Beisland, C. Phase I Clinical Trial of Cryoimmunotherapy against Prostate Cancer (CryoIT). Alden Cancer Therapy II; 2015. Available online: https:/ / clinicaltrials.gov/ct2/show / NCT02423928 (accessed on 26 April 2021).

83. Thomsen, L.C.V.; Honoré, A.; Reisæter, L.A.; Almås, B.; Førde, K.; Kristoffersen, E.K.; Melve, G.K.; Biermann, M.; Helle, S.I.; Azeem, W.; et al. A prospective phase I trial of dendritic cell-based cryoimmunotherapy in metastatic castration-resistant prostate cancer. J. Clin. Oncol. 2020, 38, 3029. [CrossRef]

84. A Study of Enzalutamide and LY3023414 in Men with Prostate Cancer. Eli Lilly and Company; 2015. Available online: https:/ / clinicaltrials.gov/ct2/show / NCT02407054 (accessed on 26 April 2021).

85. Sweeney, C.; Percent, I.J.; Babu, S.; Cultrera, J.; Mehlhaff, B.A.; Goodman, O.B.; Morris, D.; Schnadig, I.D.; Albany, C.; Shore, N.D.; et al. Phase 1b/2 study of enzalutamide (ENZ) with LY3023414 (LY) or placebo (PL) in patients (pts) with metastatic castration-resistant prostate cancer (mCRPC) after progression on abiraterone. J. Clin. Oncol. 2019, 37, 5009. [CrossRef]

86. Safety and Tolerability of Atezolizumab (ATZ) in Combination with Radium-223 Dichloride (R-223-D) in Meta-static CastrateResistant Prostate Cancer (CRPC) Progressed Following Treatment with an Androgen Pathway Inhibitor. Hoffmann-La Roche; 2016. Available online: https:/ / clinicaltrials.gov/ct2/show/NCT02814669 (accessed on 26 April 2021). 
87. Morris, M.J.; Fong, L.; Petrylak, D.P.; Sartor, A.O.; Higano, C.S.; Pagliaro, L.C.; Alva, A.S.; Appleman, L.J.; Tan, W.; Vaishampayan, U.N.; et al. Safety and clinical activity of atezolizumab (atezo) + radium-223 dichloride (r-223) in 2L metastatic castration-resistant prostate cancer (mCRPC): Results from a phase Ib clinical trial. J. Clin. Oncol. 2020, 38, 5565. [CrossRef]

88. Lee, L.S. Neoadjuvant Apalutamide (ARN509) and Radical Prostatectomy in Treatment of Intermediate to High Risk Prostate Cance. Singapore General Hospital; 2017. Available online: https:/ / clinicaltrials.gov/ct2/show / NCT03124433 (accessed on 26 April 2021).

89. A Safety and Pharmacokinetics Study of Niraparib Plus an Androgen Receptor-Targeted Therapy in Men with Metastatic Castration-Resistant Prostate Cancer (BEDIVERE). Janssen Research \& Development, LLC; 2016. Available online: https: / / clinicaltrials.gov/ct2/show/NCT02924766 (accessed on 26 April 2021).

90. Saad, F.; Chi, K.N.; Shore, N.D.; Graff, J.N.; Posadas, E.M.; Espina, B.M.; Zhu, E.; Hazra, A.; Bradic, B.; Cheng, S.; et al. Phase Ib study of niraparib plus androgen receptor-targeted therapy (ART) in patients (pts) with metastatic castration-resistant prostate cancer (mCRPC). J. Clin. Oncol. 2020, 38, 122. [CrossRef]

91. Saad, F.; Chi, K.N.; Shore, N.D.; Graff, J.N.; Posadas, E.M.; Lattouf, J.-B.; Espina, B.M.; Zhu, E.; Yu, A.; Hazra, A.; et al. Niraparib with androgen receptor-axis-targeted therapy in patients with metastatic castration-resistant prostate cancer: Safety and pharmacokinetic results from a phase $1 \mathrm{~b}$ study (BEDIVERE). Cancer Chemother. Pharmacol. 2021, 88, 25-37. [CrossRef] [PubMed]

92. Shore, N.D. Open Label Phase Two Study of Enzalutamide with Concurrent Administration of Radium Ra 223 Dichloride in Castration-Resistant (Hormone-Refractory) Prostate Cancer Subjects with Symptomatic Bone Metastasis. Carolina Research Professionals, LLC; 2015. Available online: https:/ / clinicaltrials.gov/ct2/show /NCT02507570 (accessed on 26 April 2021).

93. Shore, N.D.; Schellhammer, P.F.; Tutrone, R.F.; Mariados, N.F.; Harrelson, S.S. Open Label Phase II Study of Enzalutamide with Concurrent Administration of Radium 223 Dichloride in Patients with Castration-Resistant Prostate Cancer. Clin. Genitourin. Cancer 2020, 18, 416-422. [CrossRef] [PubMed]

94. Heath, E.I. PLX3397, Radiation Therapy, and Antihormone Therapy in Treating Patients with Intermediate- or High-Risk Prostate Cancer. Barbara Ann Karmanos Cancer Institute; 2015. Available online: https:/ / clinicaltrials.gov/ct2/show/NCT02472275 (accessed on 26 April 2021).

95. A Phase I/II Study for the Safety and Efficacy of Panitumumab in Combination with TAS-102 for Patients with Colorectal Cancer (APOLLON). Takeda; 2015. Available online: https:/ / clinicaltrials.gov/ct2/show / NCT02613221 (accessed on 26 April 2021).

96. Kato, T.; Kagawa, Y.; Komatsu, Y.; Oki, E.; Yoshino, T.; Yamazaki, K.; Yasui, H.; Satake, H.; Shibuya, K.; Oba, K.; et al. A phase I/II study for panitumumab combined with TAS-102 in patients with RAS wild-type metastatic colorectal cancer (APOLLON study): Phase I results. J. Clin. Oncol. 2017, 35, 770. [CrossRef]

97. Kuboki, Y.; Yoshino, T.; Kato, T.; Kagawa, Y.; Gamoh, M.; Yasui, H.; Yamazaki, K.; Komatsu, Y.; Satake, H.; Goto, M.; et al. APOLLON: A phase I/II study of panitumumab combined with TAS-102 in patients (pts) with RAS wild-type (wt) metastatic colorectal cancer (mCRC). J. Clin. Oncol. 2018, 36, 3523. [CrossRef]

98. O'Dwyer, P.J. Phase I/II Trial of Regorafenib, Hydroxychloroquine, and Entinostat in Metastatic Colorectal Cancer. Abramson Cancer Center of the University of Pennsylvania; 2017. Available online: https: / / clinicaltrials.gov/ct2/show / NCT03215264 (accessed on 26 April 2021).

99. Study of Magrolimab (Hu5F9-G4) in Combination with Cetuximab in Participants with Solid Tumors and Ad-vanced Colorectal Cancer. Gilead Sciences; 2016. Available online: https:/ / clinicaltrials.gov/ct2/show / NCT02953782 (accessed on 26 April 2021).

100. Fisher, G.A.; Lakhani, N.J.; Eng, C.; Hecht, J.R.; Bendell, J.C.; Philip, P.A.; O’Dwyer, P.J.; Johnson, B.; Kardosh, A.; Ippolito, T.M.; et al. A phase $\mathrm{Ib} / \mathrm{II}$ study of the anti-CD47 antibody magrolimab with cetuximab in solid tumor and colorectal cancer patients. $J$. Clin. Oncol. 2020, 38, 114. [CrossRef]

101. Aranda, E.; Gómez, A. Phase II Trial to Assess FOLFIRI+Aflibercept Efficacy in Patients with Oxaliplatin-pretreated Metastatic Colorectal Cancer with or without ACE Polymorphisms (POLAF). Spanish Cooperative Group for the Treatment of Digestive Tumours (TTD); 2016. Available online: https:/ / clinicaltrials.gov/ct2/show/NCT02970916 (accessed on 26 April 2021).

102. Ahn, J.B. Pemetrexed and Erlotinib for Metastatic Colorectal Cancer. Yonsei University; 2016. Available online: https:// clinicaltrials.gov/ct2/show/NCT02723578 (accessed on 26 April 2021).

103. Beom, S.-H.; Lee, K.-W.; Cho, S.-H.; Park, Y.; Kim, T.; Jung, M.; Shin, S.; Ahn, J.; Lee, K.H. A phase II study of pemetrexed and erlotinib for metastatic colorectal cancer refractory to standard chemotherapy. Ann. Oncol. 2018, 29, viii190. [CrossRef]

104. Phase Ib Study of PDR001 in Combination with Regorafenib in Adult Patients with Previously Treated Metastatic Colorectal Cancer. Novartis Pharmaceuticals; 2017. Available online: https:/ / clinicaltrials.gov/ct2/show / NCT03081494 (accessed on 26 April 2021).

105. Van Custem, E. A Study Evaluating S 95005 Plus Bevacizumab and Capecitabine Plus Bevacizumab in Patients with Previously Untreated Colorectal Cancer Who Are Non-eligible for Intensive Therapy (TASCO1). Institut de Recherches Internationales Servier; 2016. Available online: https:/ / clinicaltrials.gov/ct2/show/NCT02743221 (accessed on 26 April 2021).

106. Van Cutsem, E.; Danielewicz, I.; Saunders, M.; Pfeiffer, P.; Argilés, G.; Borg, C.; Glynne-Jones, R.; Punt, C.; Van de Wouw, A.; Fedyanin, M.; et al. Trifluridine/tipiracil plus bevacizumab in patients with untreated metastatic colorectal cancer ineligible for intensive therapy: The randomized TASCO1 study. Ann. Oncol. 2020, 31, 1160-1168. [CrossRef]

107. Barton, J. A Study to Evaluate eFT508 Alone and in Combination with Avelumab in Subjects with MSS Colorectal Cancer. Effector Therapeutics; 2017. Available online: https:/ / clinicaltrials.gov/ct2/show /NCT03258398 (accessed on 26 April 2021). 
108. Hubbard, J.M.; Patel, M.R.; Bekaii-Saab, T.S.; Falchook, G.S.; Freilich, B.L.; Dasari, A.; Knisely, B.T.; Anderson, M.; Chiang, G.G.; Webster, K.R.; et al. A phase II, open label, randomized, noncomparative study of eFT508 (tomivosertib) alone or in combination with avelumab in subjects with relapsed/refractory microsatellite stable colorectal cancer (MSS CRC). J. Clin. Oncol. 2019, 37, e14145. [CrossRef]

109. Open-label, Single Arm Trial of BI 695502 in Patients with Previously Untreated Metastatic Colorectal Cancer (INVICTAN $\left.{ }^{\circledR}-3\right)$. Boehringer Ingelheim; 2016. Available online: https:/ / clinicaltrials.gov/ct2/show / NCT02776683 (accessed on 26 April 2021).

110. Bokemeyer, C. Phase 1 Trial to Evaluate mFOLFOX6 with Selinexor In Patients with Metastatic Colorectal Cancer (SENTINEL). GSO Global Clinical Research BV; 2015. Available online: https: / clinicaltrials.gov/ct2/show / NCT02384850 (accessed on 26 April 2021).

111. Nilsson, S.; Stein, A.; Rolfo, C.; Kranich, A.L.; Mann, J.; Papadimitriou, K.; Theile, S.; Amberg, S.; Bokemeyer, C. Selinexor (KPT-330), an Oral Selective Inhibitor of Nuclear Export (SINE) Compound, in Combination with FOLFOX in Patients with Metastatic Colorectal Cancer (mCRC)—Final Results of the Phase I Trial SENTINEL. Curr. Cancer Drug Targets 2020, 20, 811-817. [CrossRef] [PubMed]

112. A Study Evaluating TAS-102 Plus Nivolumab in Patients with MSS CRC. Taiho Oncology, Inc.; 2016. Available online: https: / / clinicaltrials.gov/ct2/show / NCT02860546 (accessed on 26 April 2021).

113. Patel, M.R.; Falchook, G.S.; Hamada, K.; Makris, L.; Bendell, J.C. A phase 2 trial of trifluridine/tipiracil plus nivolumab in patients with heavily pretreated microsatellite-stable metastatic colorectal cancer. Cancer Med. 2021, 10, 1183-1190. [CrossRef] [PubMed]

114. Patel, M.R.; Falchook, G.S.; Hamada, K.; Makris, L.; Winkler, R.E.; Gordon, G.S.; Bendell, J.C. Results of a phase II study evaluating trifluridine/tipiracil plus nivolumab in patients with heavily pretreated microsatellite-stable (MSS) metastatic colorectal cancer (mCRC). J. Clin. Oncol. 2019, 37, 48. [CrossRef]

115. Cassier, P. Evaluation of Safety and Activity of an Anti-PDL1 Antibody (DURVALUMAB) Combined with CSF-1R TKI (PEXIDARTINIB) in Patients with Metastatic/Advanced Pancreatic or Colorectal Cancers (MEDIPLEX). Centre Leon Berard; 2016. Available online: https:/ / clinicaltrials.gov/ct2/show/NCT02777710 (accessed on 26 April 2021).

116. A Study to Investigate Efficacy and Safety of Cobimetinib Plus Atezolizumab and Atezolizumab Monotherapy Versus Regorafenib in Participants with Metastatic Colorectal Adenocarcinoma (COTEZO IMblaze370). Hoffmann-La Roche; 2016. Available online: https:/ / clinicaltrials.gov/ct2/show / NCT02788279 (accessed on 26 April 2021).

117. Eng, C.; Kim, T.W.; Bendell, J.; Argilés, G.; Tebbutt, N.C.; Di Bartolomeo, M.; Falcone, A.; Fakih, M.; Kozloff, M.; Segal, N.H.; et al. Atezolizumab with or without cobimetinib versus regorafenib in previously treated metastatic colorectal cancer (IMblaze370): A multicentre, open-label, phase 3, randomised, controlled trial. Lancet Oncol. 2019, 20, 849-861. [CrossRef]

118. Study of Cobimetinib in Combination with Atezolizumab and Bevacizumab in Participants with Gastrointestinal and Other Tumors. Hoffmann-La Roche; 2016. Available online: https://clinicaltrials.gov/ct2/show/NCT02876224 (accessed on 26 April 2021).

119. Orlandi, A. Erbitux MEtastatic Colorectal Cancer Strategy Study. 2015. Available online: https://clinicaltrials.gov/ct2/show / NCT02484833 (accessed on 26 April 2021).

120. Pinto, C.; Normanno, N.; Orlandi, A.; Maiello, E.; Bilancia, D.; Corsi, D.C.; Tamburini, E.; Pisconti, S.; Ferraú, F.; Di Costanzo, F.; et al. Cetuximab metastatic colorectal cancer strategy (ERMES) study: A phase III randomized two arm study with FOLFIRI + cetuximab until disease progression compared to FOLFIRI + cetuximab for 8 cycles followed by cetuximab alone until disease progression in first-line treatment of patients with RAS and BRAF wild type metastatic colorectal cancer. J. Clin. Oncol. 2017, 35, TPS810. [CrossRef]

121. Pinto, C.; Normanno, N.; Orlandi, A.; Fenizia, F.; Damato, A.; Maiello, E.; Tamburini, E.; Di Costanzo, F.; Tonini, G.; Bilancia, D.; et al. Phase III study with FOLFIRI + cetuximab versus FOLFIRI + cetuximab followed by cetuximab alone in RAS and BRAF WT mCRC. Futur. Oncol. 2018, 14, 1339-1346. [CrossRef]

122. Cohen, D.J. Study of Irinotecan and AZD1775, a Selective Wee 1 Inhibitor, in RAS or BRAF Mutated, Second-line Metastatic Colorectal Cancer. NYU Langone Health; 2016. Available online: https:/ / clinicaltrials.gov/ct2/show/NCT02906059 (accessed on 26 April 2021).

123. Cohen, D.J.; Grabocka, E.; Bar-Sagi, D.; Godin, R.; Leichman, L.P. A phase Ib study combining irinotecan with AZD1775, a selective WEE 1 kinase inhibitor, in RAS/RAF mutated metastatic colorectal cancer patients who progressed on first line therapy. J. Clin. Oncol. 2017, 35, TPS3627. [CrossRef]

124. A Study of Brontictuzumab with Chemotherapy for Subjects with Previously Treated Metastatic Colorectal Cancer. OncoMed Pharmaceuticals, Inc.; 2017. Available online: https:/ / clinicaltrials.gov/ct2/show/NCT03031691 (accessed on 26 April 2021).

125. A Phase 1a/b Dose Escalation Study of the Safety, Pharmacokinetics, and Pharmacodynamics of OMP-131R10. On-coMed Pharmaceuticals, Inc.; 2015. Available online: https:/ / clinicaltrials.gov/ct2/show / NCT02482441 (accessed on 26 April 2021).

126. Safety and Efficacy Study of AMG 820 and Pembrolizumab Combination in Select Advanced Solid Tumor Cancer. Amgen; 2016. Available online: https:// clinicaltrials.gov/ct2/show / NCT02713529 (accessed on 26 April 2021).

127. Razak, A.R.; Cleary, J.M.; Moreno, V.; Boyer, M.; Aller, E.C.; Edenfield, W.; Tie, J.; Harvey, R.D.; Rutten, A.; Shah, M.A.; et al. Safety and efficacy of AMG 820, an anti-colony-stimulating factor 1 receptor antibody, in combination with pembrolizumab in adults with advanced solid tumors. J. Immunother. Cancer 2020, 8, e001006. [CrossRef]

128. Chen, J. Safety and Efficiency of IRE Plus $\gamma \delta$ T Cell against Locally Advanced Pancreatic Cancer; Fuda Cancer Hospital: Guangzhou, China, 2017. Available online: https: / / clinicaltrials.gov/ct2/show/NCT03180437 (accessed on 26 April 2021). 
129. Lin, M.; Zhang, X.; Liang, S.; Luo, H.; Alnaggar, M.; Liu, A.; Yin, Z.; Chen, J.; Niu, L.; Jiang, Y. Irreversible electroporation plus allogenic $\mathrm{V} \gamma 9 \mathrm{~V} \delta 2 \mathrm{~T}$ cells enhances antitumor effect for locally advanced pancreatic cancer patients. Signal. Transduct. Target. Ther. 2020, 5, 1-9. [CrossRef]

130. Niu, L. Combination of Irreversible Electroporation and NK Immunotherapy for Advanced Pancreatic Cancer; Fuda Cancer Hospital: Guangzhou, China, 2016. Available online: https:/ / clinicaltrials.gov/ct2/show/NCT02718859 (accessed on 26 April 2021).

131. Benaim, E. RX-3117 in Combination with Abraxane ${ }^{\circledR}$ in Subjects with Metastatic Pancreatic Cancer. Rexahn Phar-Maceuticals, Inc.; 2017. Available online: https:/ / clinicaltrials.gov/ct2/show/NCT03189914 (accessed on 26 April 2021).

132. Babiker, H.M.; Schlegel, P.J.; Hicks, L.G.; Bullock, A.J.; Burhani, N.; Benaim, E.; Peterson, C.; Heaton, C.; Ocean, A.J. A phase I/II study of RX-3117, an oral antimetabolite nucleoside, in combination with nab-paclitaxel (nab-pac) as first-line treatment of metastatic pancreatic cancer (met-PC): Preliminary results. J. Clin. Oncol. 2019, 37, 420. [CrossRef]

133. Wilmink, J.W. Phase I/II Study of LDE225 with Gemcitabine and Nab-paclitaxel in Patients with Pancreatic Cancer (MATRIX). Academisch Medisch Centrum-Universiteit van Amsterdam (AMC-UvA); 2015. Available online: https://clinicaltrials.gov/ct2 / show / NCT02358161 (accessed on 26 April 2021).

134. Pijnappel, E.; Klaassen, R.; Van Der Lee, K.; Van Empel, M.P.; Richel, D.; Legdeur, M.; Nederveen, A.; Van Laarhoven, H.; Wilmink, H. Phase I/II study of LDE225 in combination with gemcitabine and nab-paclitaxel in patients with metastatic pancreatic cancer. Ann. Oncol. 2019, 30, v265. [CrossRef]

135. Ramanathan, R.K. BPM31510 Administered Intravenously with Gemcitabine in Advanced Pancreatic Cancer Patients. Berg, LLC; 2016. Available online: https:/ / clinicaltrials.gov/ct2/show/NCT02650804 (accessed on 26 April 2021).

136. Kundranda, M.N.; Propper, D.; Ritch, P.S.; Strauss, J.; Hidalgo, M.; Gillmore, R.; Sarangarajan, R.; Narain, N.R.; Kiebish, M.A.; Rodrigues, L.O.; et al. Phase II trial of BPM31510-IV plus gemcitabine in advanced pancreatic ductal adenocarcinomas (PDAC). J. Clin. Oncol. 2020, 38, 723. [CrossRef]

137. Olaptesed (NOX-A12) Alone and in Combination with Pembrolizumab in Colorectal and Pancreatic Cancer (Key-note-559). NOXXON Pharma AG; 2017. Available online: https:/ / clinicaltrials.gov/ct2/show/NCT03168139 (accessed on 26 April 2021).

138. Halama, N.; Prüfer, U.; Froemming, A.; Beyer, D.; Eulberg, D.; Jungnelius, J.; Mangasarian, A. Phase I/II study with CXCL12 inhibitor NOX-A12 and pembrolizumab in patients with microsatellite-stable, metastatic colorectal or pancreatic cancer. Ann. Oncol. 2019, 30, v231. [CrossRef]

139. Halama, N.; Pruefer, U.; Frömming, A.; Beyer, D.; Eulberg, D.; Jungnelius, J.U.B.; Mangasarian, A. Experience with CXCL12 inhibitor NOX-A12 plus pembrolizumab in patients with microsatellite-stable, metastatic colorectal or pancreatic cancer. J. Clin. Oncol. 2019, 37, e14143. [CrossRef]

140. Cohen, D.J. Study of Nivolumab, Cabiralizumab, and Stereotactic Body Radiotherapy (SBRT) for Locally Advanced Unresectable Pancreatic Cancer. NYU Langone Health; 2018. Available online: https://www.clinicaltrials.gov/ct2/show/NCT03599362 (accessed on 26 April 2021).

141. Cohen, D.J.; Medina, B.; Du, K.L.; Coveler, A.L.; Manji, G.A.; Oberstein, P.E.; Perna, S.K.; Miller, G. Phase II multi-institutional study of nivolumab (Nivo), cabiralizumab (Cabira), and stereotactic body radiotherapy (SBRT) for locally advanced unresectable pancreatic cancer (LAUPC). J. Clin. Oncol. 2019, 37, TPS4163. [CrossRef]

142. Niu, L. Simultaneous Gemcitabine and Irreversible Electroporation for Locally Advanced Pancreatic Cancer; Fuda Cancer Hospital: Guangzhou, China, 2016. Available online: https:/ / clinicaltrials.gov/ct2/show/NCT02981719 (accessed on 26 April 2021).

143. Study of Pegilodecakin (LY3500518) with FOLFOX Compared to FOLFOX Alone Second-line Tx in Participants With Metastatic Pancreatic Cancer (Sequoia). Eli Lilly and Company; 2016. Available online: https://clinicaltrials.gov/ct2/show /NCT02923921 (accessed on 26 April 2021).

144. Hecht, J.R.; Lonardi, S.; Bendell, J.C.; Sim, H.-W.; Macarulla, T.; Lopez, C.D.; Van Cutsem, E.; Martin, A.J.M.; Park, J.O.; Greil, R.; et al. Randomized Phase III Study of FOLFOX Alone and with Pegilodecakin as Second-line Therapy in Patients with Metastatic Pancreatic Cancer (SEQUOIA). J. Clin. Oncol. 2020, 38, 637. [CrossRef]

145. Wong, H.C. QUILT-2.001: ALT-803 in Patients with Advanced Pancreatic Cancer in Conjunction with Gemcitabine and Nab-Paclitaxel. Altor BioScience; 2015. Available online: https://clinicaltrials.gov/ct2/show/NCT02559674 (accessed on 26 April 2021).

146. Acoba, J.D.; Rock, A.; Wong, H.C. Phase Ib/II study of ALT-803 in combination with gemcitabine and nab-paclitaxel in patients with advanced pancreatic cancer. J. Clin. Oncol. 2017, 35, TPS510. [CrossRef]

147. ACP-196 Alone and in Combination with Pembrolizumab in Subjects with Advanced or Metastatic Pancreatic Cancer (KEYNOTE144). Acerta Pharma BV; 2015. Available online: https:/ / clinicaltrials.gov/ct2/show / NCT02362048 (accessed on 26 April 2021).

148. Overman, M.; Javle, M.; Davis, R.E.; Vats, P.; Kumar-Sinha, C.; Xiao, L.; Mettu, N.B.; Parra, E.R.; Benson, A.B.; Lopez, C.D.; et al. Randomized phase II study of the Bruton tyrosine kinase inhibitor acalabrutinib, alone or with pembrolizumab in patients with advanced pancreatic cancer. J. Immunother. Cancer 2019, 8, e000587. [CrossRef]

149. A Study of Galunisertib (LY2157299) and Durvalumab (MEDI4736) in Participants with Metastatic Pancreatic Cancer. Eli Lilly and Company; 2016. Available online: https://clinicaltrials.gov/ct2/show/NCT02734160 (accessed on 26 April 2021).

150. Melisi, D.; Oh, D.-Y.; Hollebecque, A.; Calvo, E.; Varghese, A.; Borazanci, E.; Macarulla, T.; Merz, V.; Zecchetto, C.; Zhao, Y.; et al. Safety and activity of the TGF $\beta$ receptor I kinase inhibitor galunisertib plus the anti-PD-L1 antibody durvalumab in metastatic pancreatic cancer. J. Immunother. Cancer 2021, 9, e002068. [CrossRef] [PubMed] 
151. Melisi, D.; Hollebecque, A.; Oh, D.-Y.; Calvo, E.; Varghese, A.M.; Borazanci, E.H.; Mercade, T.M.; Simionato, F.; Park, J.O.; Bendell, J.C.; et al. A phase $\mathrm{Ib}$ dose-escalation and cohort-expansion study of safety and activity of the transforming growth factor (TGF) $\beta$ receptor I kinase inhibitor galunisertib plus the anti-PD-L1 antibody durvalumab in metastatic pancreatic cancer. J. Clin. Oncol. 2019, 37, 4124. [CrossRef]

152. Vonderheide, R. Study of Neo-Adjuvant RO7009789 Alone or Neo-Adjuvant RO7009789 Plus Nab-Paclitaxel and Gemcitabine Followed by Adjuvant RO7009789 Plus Nab-Paclitaxel and Gemcitabine for Patients with Newly Diagnosed Resectable Pancreatic Carcinoma. Abramson Cancer Center of the University of Pennsylvania; 2015. Available online: https://clinicaltrials.gov/ct2 / show / NCT02588443 (accessed on 26 April 2021).

153. Kuśnierz, K. Clinical Phase II Clinical Study Evaluating the Toxicity and Efficacy of mFOLFIRINOX Associated with SBRT (Stereotactic Radiotherapy) in Patients with Unresectable Locally Advanced Pancreatic Cancer. Medical University of Silesia; 2019. Available online: https:/ / clinicaltrials.gov/ct2/show/NCT03891472 (accessed on 26 April 2021).

154. Rudloff, U. M7824 (MSB0011359C) in Combination with Gemcitabine in Adults with Previously Treated Advanced Adenocarcinoma of the Pancreas. National Cancer Institute (NCI); 2018. Available online: https:/ / clinicaltrials.gov/ct2/show/NCT03451773 (accessed on 26 April 2021).

155. A Study of Napabucasin Plus Nab-Paclitaxel with Gemcitabine in Adult Patients with Metastatic Pancreatic Adenocarcinoma (CanStem111P). Sumitomo Dainippon Pharma Oncology, Inc.; 2016. Available online: https:/ / clinicaltrials.gov/ct2/show/NCT0 2993731 (accessed on 26 April 2021).

156. Bekaii-Saab, T.S.; Li, C.-P.; Okusaka, T.; O’Neil, B.H.; Reni, M.; Tabernero, J.; Qin, S.; Van Cutsem, E.; Borodyansky, L.; Li, C. CanStem111P trial: A phase III study of napabucasin (BBI-608) plus nab-paclitaxel (nab-PTX) with gemcitabine (gem) in adult patients with metastatic pancreatic adenocarcinoma (mPDAC). J. Clin. Oncol. 2017, 35, TPS4148. [CrossRef]

157. Sonbol, M.; Ahn, D.H.; Goldstein, D.; Okusaka, T.; Tabernero, J.; Macarulla, T.; Reni, M.; Li, C.-P.; O’Neil, B.; Van Cutsem, E.; et al. CanStem111P trial: A Phase III study of napabucasin plus nab-paclitaxel with gemcitabine. Futur. Oncol. 2019, 15, 1295-1302. [CrossRef]

158. Dave, D.; Desai, U.; Despande, N. Photodynamic Therapy: A View through Light. J. Orofac. Res. 2012, 2, 82-86. [CrossRef]

159. Oniszczuk, A.; Wojtunik-Kulesza, K.A.; Oniszczuk, T.; Kasprzak, K. The potential of photodynamic therapy (PDT)—Experimental investigations and clinical use. Biomed. Pharmacother. 2016, 83, 912-929. [CrossRef]

160. Allison, R.R.; Downie, G.H.; Cuenca, R.; Hu, X.; Childs, C.J.; Sibata, C.H.; Allison, R.R.; Downie, G.H.; Cuenca, R.; Hu, X.; et al. Photosensitizers in clinical PDT. Photodiagnosis Photodyn. Ther. 2004, 1, 27-42. [CrossRef]

161. Kataoka, H.; Nishie, H.; Hayashi, N.; Tanaka, M.; Nomoto, A.; Yano, S.; Joh, T. New photodynamic therapy with next-generation photosensitizers. Ann. Transl. Med. 2017, 5, 183. [CrossRef] [PubMed]

162. Abrahamse, H.; Hamblin, M.R. New photossensitizersfot photodynamic therapy. Biochem. J. 2017, 473, 347-364. [CrossRef] [PubMed]

163. Rivera, J.A.R.; Medina, M.L.V.M.; Zegarra, M.L.; Rodriguez, R. Efficacy, Safety and Quality of Life After TOOKAD ${ }^{\circledR}$ Soluble VTP for Localized Prostate Cancer (PCM304). Steba Biotech S.A.; 2013. Available online: https://clinicaltrials.gov/ct2/show/NCT018 75393 (accessed on 26 April 2021).

164. Emberton, M. Efficacy and Safety Study of TOOKAD ${ }^{\circledR}$ Soluble for Localised Prostate Cancer Compared to Active Surveillance. (PCM301). Steba Biotech S.A.; 2019. Available online: https://clinicaltrials.gov/ct2/show/NCT01310894 (accessed on 26 April 2021).

165. Trachtenberg, J. Study of WST09 in Prostate Cancer after Radiation: Repeat Procedure. STEBA France; 2010. Available online: https: / / clinicaltrials.gov/ct2/show / NCT00305929 (accessed on 26 April 2021).

166. Trachtenberg, J. Phase II/III Study of WST09 in Prostate Cancer after Radiation Therapy. STEBA France; 2010. Available online: https:/ / clinicaltrials.gov/ct2/show/NCT00312442 (accessed on 26 April 2021).

167. Almeida, L. Photodynamic Therapy with LUZ11 in Advanced Head and Neck Cancer. Luzitin SA; 2016. Available online: https:/ / clinicaltrials.gov/ct2/show / NCT02070432 (accessed on 26 April 2021).

168. Daniell, M.D.; Hill, J.S. A History of Photodynamic Therapy. ANZ J. Surg. 1991, 61, 340-348. [CrossRef] [PubMed]

169. Ackroyd, R.; Kelty, C.; Brown, N.; Reed, M. The History of Photodetection and Photodynamic Therapy. Photochemistry Photobiol. 2001, 74, 656-669. [CrossRef]

170. Brancaleon, L.; Moseley, H.; Brancaleon, L.; Moseley, H. Laser and Non-laser Light Sources for Photodynamic Therapy. Lasers Med. Sci. 2002, 17, 173-186. [CrossRef]

171. Zhang, C.; Chen, W.; Zhang, T.; Jiang, X.; Hu, Y. Hybrid nanoparticle composites applied to photodynamic therapy: Strategies and applications. J. Mater. Chem. B 2020, 8, 4726-4737. [CrossRef]

172. Fukumura, D.; Jain, R.K. Tumor microenvironment abnormalities: Causes, consequences, and strategies to normalize. J. Cell. Biochem. 2006, 101, 937-949. [CrossRef] [PubMed]

173. Joyce, J.A. Therapeutic targeting of the tumor microenvironment. Cancer Cell 2005, 7, 513-520. [CrossRef] [PubMed]

174. Bristow, R.G.; Hill, R.P.; Bristow, R.G.; Hill, R.P. Hypoxia, DNA repair and genetic instability. Nat. Rev. Cancer 2008, 8, 180-192. [CrossRef]

175. Semenza, G.L. The hypoxic tumor microenvironment: A driving force for breast cancer progression. Biochim. et Biophys. Acta (BBA) Bioenerg. 2016, 1863, 382-391. [CrossRef] [PubMed] 
176. Vaupel, P.; Mayer, A. Hypoxia in cancer: Significance and impact on clinical outcome. Cancer Metastasis Rev. 2007, $26,225-239$. [CrossRef]

177. Protsiv, M.; Ley, C.; Lankester, J.; Hastie, T.; Parsonnet, J. Decreasing human body temperature in the United States since the Industrial Revolution. eLife 2020, 9. [CrossRef]

178. Geneva, I.; Cuzzo, B.; Fazili, T.; Javaid, W. Normal Body Temperature: A Systematic Review. Open Forum Infect. Dis. 2019, 6, ofz032. [CrossRef]

179. Liu, Z. Clinical effects of high frequency hyperthermia-assisted irinotecan chemotherapy on patients with middle and advanced colorectal cancer and its safety assessment. Oncol. Lett. 2018, 17, 215-220. [CrossRef]

180. Tempel, N.V.D.; Horsman, M.; Kanaar, R. Improving efficacy of hyperthermia in oncology by exploiting biological mechanisms. Int. J. Hyperth. 2016, 32, 446-454. [CrossRef]

181. Hildebrandt, B.; Wust, P.; Ahlers, O.; Dieing, A.; Sreenivasa, G.; Kerner, T.; Felix, R.; Riess, H. The cellular and molecular basis of hyperthermia. Crit Rev. Oncol Hematol. 2002, 116, 69-75. [CrossRef]

182. Guillemin, P.; Gui, L.; Lorton, O.; Zilli, T.; Crowe, L.A.; Desgranges, S.; Montet, X.; Terraz, S.; Miralbell, R.; Salomir, R.; et al Mild hyperthermia by MR-guided focused ultrasound in an ex vivo model of osteolytic bone tumour: Optimization of the spatio-temporal control of the delivered temperature. J. Transl. Med. 2019, 17, 1-19. [CrossRef] [PubMed]

183. Piotr, G.A.S. Essential Facts on the History of Hyperthermia and their Connections with Electromedicine. arXiv 2017, 12, 37-40.

184. Szasz, A.; Iluri, N.; Szasz, O. Local Hyperthermia in Oncology-To Choose or not to Choose? In Hyperthermia; IntechOpen: London, UK, 2013. [CrossRef]

185. Seynhaeve, A.; Amin, M.; Haemmerich, D.; van Rhoon, G.; Hagen, T.T. Hyperthermia and smart drug delivery systems for solid tumor therapy. Adv. Drug Deliv. Rev. 2020, 163-164, 125-144. [CrossRef]

186. MacEwan, S.R.; Callahan, D.J.; Chilkoti, A. Stimulus-responsive macromolecules and nanoparticles for cancer drug delivery. Nanomedicine 2010, 5, 793-806. [CrossRef] [PubMed]

187. Matteucci, M.L.; Anyarambhatla, G.; Rosner, G.; Azuma, C.; Fisher, P.E.; Dewhirst, M.W.; Needham, D.; Thrall, D.E. Hyperthermia increases accumulation of technetium-99m-labeled liposomes in feline sarcomas. Clin. Cancer Res. 2000, 6, 3748-3755.

188. Rao, W.; Deng, Z.-S.; Liu, J. A Review of Hyperthermia Combined with Radiotherapy/Chemotherapy on Malignant Tumors. Crit. Rev. Biomed. Eng. 2010, 38, 101-116. [CrossRef] [PubMed]

189. Oei, A.L.; Vriend, L.E.M.; Crezee, J.; Franken, N.A.P.; Krawczyk, P.M. Effects of hyperthermia on DNA repair pathways: One treatment to inhibit them all. Radiat. Oncol. 2015, 10, 1-13. [CrossRef]

190. Ahmed, K.; Zaidi, S.F. Treating cancer with heat: Hyperthermia as promising strategy to enhance apoptosis. J. Pak. Med. Assoc. 2013, 63, 504-508.

191. Lapin, N.A.; Krzykawska-Serda, M.; Dilliard, S.; Mackeyev, Y.; Serda, M.; Wilson, L.J.; Curley, S.A.; Corr, S.J. The effects of non-invasive radiofrequency electric field hyperthermia on biotransport and biodistribution of fluorescent [60]fullerene derivative in a murine orthotopic model of breast adenocarcinoma. J. Control. Release 2017, 260, 92-99. [CrossRef]

192. Huang, S.H.; Yang, K.J.; Wu, J.C.; Chang, K.J.; Wang, S.M. Effects of hyperthermia on the cytoskeleton and focal adhesion proteins in a human thyroid carcinoma cell line. J. Cell. Biochem. 1999, 75, 327-337. [CrossRef]

193. Eppink, B.; Krawczyk, P.M.; Stap, J.; Kanaar, R. Hyperthermia-induced DNA repair deficiency suggests novel therapeutic anti-cancer strategies. Int. J. Hyperth. 2012, 28, 509-517. [CrossRef]

194. Bouwman, P.; Jonkers, J. The effects of deregulated DNA damage signalling on cancer chemotherapy response and resistance. Nat. Rev. Cancer 2012, 12, 587-598. [CrossRef]

195. Frey, B.; Weiss, E.-M.; Rubner, Y.; Wunderlich, R.; Ott, O.J.; Sauer, R.; Fietkau, R.; Gaipl, U.S. Old and new facts about hyperthermiainduced modulations of the immune system. Int. J. Hyperth. 2012, 28, 528-542. [CrossRef]

196. Alanazi, F.K.; Radwan, A.A.; Alsarra, I. Biopharmaceutical applications of nanogold. Saudi Pharm. J. 2010, 18, 179-193. [CrossRef]

197. Gao, D.; Guo, X.; Zhang, X.; Chen, S.; Wang, Y.; Chen, T.; Huang, G.; Gao, Y.; Tian, Z.; Yang, Z. Multifunctional phototheranostic nanomedicine for cancer imaging and treatment. Mater. Today Bio 2020, 5, 100035. [CrossRef]

198. Academy, B.; Gomes, A.N.A.T.P.C.; Neves, M.G.P.M.S.; Qu, C.; Naturais, P. Cancer, Photodynamic Therapy and Porphyrin-Type Derivatives. An. da Acad. Bras. de Ciências 2018, 90, 993-1026.

199. Ito, H.; Tamura, M.; Matsui, H.; Majima, H.J.; Indo, H.P.; Hyodo, I. Isoflavone intake inhibits the development of 7,12 dimethylbenz(a)anthracene(DMBA) induced mammary tumors in normal andovariectomized rats. J. Clin. Biochem. Nutr. 2014, 54, 31-38. [CrossRef]

200. Master, A. Megan, L.; Anirban, S.G. Pustaka 1. J. Control. Release 2014, 168, 88-102. [CrossRef]

201. Xia, J.; Qian, M.; Yao, Q.; Meng, Z.; Cui, H.; Zhang, L.; Li, Y.; Wu, S.; Wang, J.; Chen, Q.; et al. Synthetic infrared nanophotosensitizers with hierarchical zoom-in target-delivery functionalities for precision photodynamic therapy. J. Control. Release 2021, 334, 263-274. [CrossRef] [PubMed]

202. Ji, C.; Yuan, A.; Xu, L.; Zhang, F.; Zhang, S.; Zhao, X.; Liu, G.; Chen, W.; Guo, H. Activatable Photodynamic Therapy for Prostate Cancer by NIR Dye/Photosensitizer Loaded Albumin Nanoparticles. J. Biomed. Nanotechnol. 2019, 15, 311-318. [CrossRef]

203. Gas, P. Temperature Distribution of Human Tissue in Interstitial Microwave Hyperthermia. Przeglad Elektrotechniczny 2012, 88, 144-146.

204. Petrova, N.V.; Velichko, A.K.; Razin, S.V.; Kantidze, O.L. Early S-phase cell hypersensitivity to heat stress. Cell Cycle 2016, 15, 337-344. [CrossRef] [PubMed] 
205. Yavelsky, V.; Vais, O.; Piura, B.; Wolfson, M.; Rabinovich, A.; Fraifeld, V. The role of Hsp90 in cell response to hyperthermia. J. Therm. Biol. 2004, 29, 509-514. [CrossRef]

206. Kurokawa, H.; Ito, H.; Terasaki, M.; Matsui, H. Hyperthermia enhances photodynamic therapy by regulation of HCP1 and ABCG2 expressions via high level ROS generation. Sci. Rep. 2019, 9, 1-8. [CrossRef]

207. Caglar, E.; Dobrucali, A. Self-Expandable Metallic Stent Placement in the Palliative Treatment of Malignant Obstruction of Gastric Outlet and Duodenum. Clin. Endosc. 2013, 46, 59-64. [CrossRef]

208. Robertson, C.; Evans, D.H.; Abrahamse, H. Photodynamic therapy (PDT): A short review on cellular mechanisms and cancer research applications for PDT. J. Photochem. Photobiol. B Biol. 2009, 96, 1-8. [CrossRef]

209. Moor, A.C. Signaling pathways in cell death and survival after photodynamic therapy. J. Photochem. Photobiol. B Biol. 2000, 57, 1-13. [CrossRef]

210. Hwang, H.S.; Shin, H.; Han, J.; Na, K. Combination of photodynamic therapy (PDT) and anti-tumor immunity in cancer therapy. J. Pharm. Investig. 2018, 48, 143-151. [CrossRef]

211. Allison, R.R.; Moghissi, K. Photodynamic Therapy (PDT): PDT Mechanisms. Clin. Endosc. 2013, 46, 24-29. [CrossRef] [PubMed]

212. Allegra, A.; Pioggia, G.; Tonacci, A.; Musolino, C.; Gangemi, S.; Allegra, A.; Pioggia, G.; Tonacci, A.; Musolino, C.; Gangemi, S. Oxidative Stress and Photodynamic Therapy of Skin Cancers: Mechanisms, Challenges and Promising Developments. Antioxidants 2020, 9, 448. [CrossRef] [PubMed]

213. Dos Santos, K.M.M.G.; Cordeiro, M.E.R.; Pereira, M.C.D.S.; Barbosa, D.; Pezzini, A.A.; Kerppers, I.I. Comparative study in photodynamic therapy using the same photosensitizer in tissue repair after second-degree burns in an experimental model. Lasers Dent. Sci. 2019, 4, 17-24. [CrossRef]

214. Hou, C.-H.; Lin, F.-L.; Hou, S.-M.; Liu, J.-F. Hyperthermia Induces Apoptosis through Endoplasmic Reticulum and Reactive Oxygen Species in Human Osteosarcoma Cells. Int. J. Mol. Sci. 2014, 15, 17380-17395. [CrossRef]

215. Christensen, T.; Wahl, A.; Smedshammer, L.; Christensen, T.; Wahl, A.; Smedshammer, L. Effects of haematoporphyrin derivative and light in combination with hyperthermia on cells in culture. Br. J. Cancer 1984, 50, 85-89. [CrossRef]

216. Krishnamurthy, P.; Schuetz, J.D. The role of ABCG2 and ABCB6 in porphyrin metabolism and cell survival. Curr. Pharm. Biotechnol. 2011, 12, 647-655. [CrossRef]

217. Liang, L.; Bi, W.; Tian, Y. Autophagy in photodynamic therapy. Trop. J. Pharm. Res. 2016, 15, 885. [CrossRef]

218. Oleinick, N.L. Initiation of Autophagy by Photodynamic Therapy David. Methods Enzym. 2009, 453, 1-16. [CrossRef]

219. Mroz, P.; Yaroslavsky, A.; Kharkwal, G.B.; Hamblin, M.R. Cell Death Pathways in Photodynamic Therapy of Cancer. Cancers 2011, 3, 2516-2539. [CrossRef]

220. Moy, A.J.; Tunnell, J.W. Combinatorial immunotherapy and nanoparticle mediated hyperthermia. Adv. Drug Deliv. Rev. 2017, 114, 175-183. [CrossRef]

221. Gordon, R.; Hines, J.; Gordon, D. Intracellular hyperthermia a biophysical approach to cancer treatment via intracellular temperature and biophysical alterations. Med. Hypotheses 1979, 5, 83-102. [CrossRef]

222. Baronzio, G.; Parmar, G.; Baronzio, M.; Baronzio, G.; Parmar, G.; Baronzio, M. Overview of Methods for Overcoming Hindrance to Drug Delivery to Tumors, with Special Attention to Tumor Interstitial Fluid. Front. Oncol. 2015, 5, 165. [CrossRef] [PubMed]

223. Gallagher-Colombo, S.M.; Maas, A.L.; Yuan, M.; Busch, T.M. Photodynamic Therapy-Induced Angiogenic Signaling: Consequences and Solutions to Improve Therapeutic Response. Isr. J. Chem. 2012, 52, 681-690. [CrossRef] [PubMed]

224. Srivatsan, A.; Rao, K.V.R.; Chen, Y.; Wang, Y.; Batt, C.; Morgan, J.; Sen, A.; Repasky, E.; Pandey, R.K. Effect of hyperthermia on PDT and imaging. In Proceedings of the 12th World Congress of the International Photodynamic Association, Seattle, WA, USA, 11-15 June 2009. [CrossRef]

225. Song, C.W.; Shakil, A.; Osborn, J.L.; Iwata, K. Tumour oxygenation is increased by hyperthermia at mild temperatures. Int. J. Hyperth. 2009, 25, 91-95. [CrossRef]

226. Lv, Z.; Wei, H.; Li, Q.; Su, X.; Liu, S.; Zhang, K.Y.; Lv, W.; Zhao, Q.; Li, X.; Huang, W. Achieving efficient photodynamic therapy under both normoxia and hypoxia using cyclometalated $\mathrm{Ru}(\mathrm{ii})$ photosensitizer through type I photochemical process. Chem. Sci. 2017, 9, 502-512. [CrossRef]

227. Hegyi, G.; Szigeti, G.P.; Szász, A. Hyperthermia versus Oncothermia: Cellular Effects in Complementary Cancer Therapy. Evid. Based Complement. Altern. Med. 2013, 2013, 1-12. [CrossRef]

228. Firczuk, M.; Nowis, D.; Golab, J. PDT-induced inflammatory and host responses. Photochem. Photobiol. Sci. 2011, 10, 653-663. [CrossRef]

229. Gollnick, S.; Evans, S.S.; Baumann, H.; Owczarczak, B.; Maier, P.; Vaughan, L.; Wang, W.C.; Unger, E.; Henderson, B.W. Role of cytokines in photodynamic therapy-induced local and systemic inflammation. Br. J. Cancer 2003, 88, 1772-1779. [CrossRef]

230. Calderwood, S.K.; Thériault, J.R.; Gong, J. How is the immune response affected by hyperthermia and heat shock proteins? Int. J. Hyperth. 2005, 21, 713-716. [CrossRef]

231. Zhang, Y.; Zhang, W.; Geng, C.; Lin, T.; Wang, X.; Zhao, L.; Tang, J. Thermal ablation versus conventional regional hyperthermia has greater anti-tumor activity against melanoma in mice by upregulating CD4+ cells and enhancing IL-2 secretion. Prog. Nat. Sci. 2009, 19, 1699-1704. [CrossRef]

232. Jolesch, A.; Elmer, K.; Bendz, H.; Issels, R.; Noessner, E. Hsp70, a messenger from hyperthermia for the immune system. Eur. J. Cell Biol. 2012, 91, 48-52. [CrossRef] 
233. Taratula, O.; Dani, R.K.; Schumann, C.; Xu, H.; Wang, A.; Song, H.; Dhagat, P.; Taratula, O. Multifunctional nanomedicine platform for concurrent delivery of chemotherapeutic drugs and mild hyperthermia to ovarian cancer cells. Int. J. Pharm. 2013, 458, 169-180. [CrossRef] [PubMed]

234. Reginato, E.; Wolf, P.; Hamblin, M.R. Immune response after photodynamic therapy increases anti-cancer and anti-bacterial effects. World J. Immunol. 2014, 4, 1-11. [CrossRef] [PubMed]

235. Zhang, H.-G.; Mehta, K.; Cohen, P.; Guha, C. Hyperthermia on immune regulation: A temperature's story. Cancer Lett. 2008, 271, 191-204. [CrossRef]

236. Basu, S. Fever-like temperature induces maturation of dendritic cells through induction of hsp90. Int. Immunol. 2003, 15, 1053-1061. [CrossRef]

237. Yan, X.; Xiu, F.; An, H.; Wang, X.; Wang, J.; Cao, X. Fever range temperature promotes TLR4 expression and signaling in dendritic cells. Life Sci. 2007, 80, 307-313. [CrossRef]

238. Ito, A.; Shinkai, M.; Honda, H.; Wakabayashi, T.; Yoshida, J.; Kobayashi, T.; Ito, A.; Shinkai, M.; Honda, H.; Wakabayashi, T.; et al. Augmentation of MHC class I antigen presentation via heat shock protein expression by hyperthermia. Cancer Immunol. Immunother. 2001, 50, 515-522. [CrossRef]

239. Han, W.; Zhang, S.; Deng, R.; Du, Y.; Qian, J.; Zheng, X.; Xu, B.; Xie, Z.; Yan, F.; Tian, W. Self-assembled nanostructured photosensitizer with aggregation-induced emission for enhanced photodynamic anticancer therapy. Sci. China Mater. 2019, 63, 136-146. [CrossRef]

240. Jin, C.S.; Zheng, G. Liposomal nanostructures for photosensitizer delivery. Lasers Surg. Med. 2011, 43, 734-748. [CrossRef] [PubMed]

241. Seidi, K.; Neubauer, H.; Moriggl, R.; Jahanban-Esfahlan, R.; Javaheri, T. Tumor target amplification: Implications for nano drug delivery systems. J. Control. Release 2018, 275, 142-161. [CrossRef] [PubMed]

242. Liu, X.; Zhang, Y.; Wang, Y.; Zhu, W.; Li, G.; Ma, X.; Chen, S.; Tiwari, S.; Shi, K.; Zhang, S.; et al. Comprehensive understanding of magnetic hyperthermia for improving antitumor therapeutic efficacy. Theranostics 2020, 10, 3793-3815. [CrossRef] [PubMed]

243. Kim, J.; Jo, Y.-U.; Na, K. Photodynamic therapy with smart nanomedicine. Arch. Pharmacal Res. 2020, 43, 22-31. [CrossRef] [PubMed]

244. Ambasta, R.K.; Sharma, A.; Kumar, P.; Ambasta, R.K.; Sharma, A.; Kumar, P. Nanoparticle mediated targeting of VEGFR and cancer stem cells for cancer therapy. Vasc. Cell 2011, 3, 26. [CrossRef]

245. Eldar-Finkelman, H. Glycogen synthase kinase 3: An emerging therapeutic target. Trends Mol. Med. 2002, 8, 126-132. [CrossRef]

246. Barańska, E.; Wiecheć-Cudak, O.; Rak, M.; Bienia, A.; Mrozek-Wilczkiewicz, A.; Krzykawska-Serda, M.; Serda, M. Interactions of a Water-Soluble Glycofullerene with Glucose Transporter 1. Analysis of the Cellular Effects on a Pancreatic Tumor Model. Nanomaterials 2021, 11, 513. [CrossRef] [PubMed]

247. Beltrán-Gracia, E.; López-Camacho, A.; Higuera-Ciapara, I.; Velázquez-Fernández, J.B.; Vallejo-Cardona, A.A. Nanomedicine review: Clinical developments in liposomal applications. Cancer Nanotechnol. 2019, 10,1-40. [CrossRef]

248. Ahirwar, S.; Mallick, S.; Bahadur, D. Photodynamic therapy using graphene quantum dot derivatives. J. Solid State Chem. 2020, 282, 121107. [CrossRef]

249. Chen, J.; Wu, W.; Zhang, F.; Zhang, J.; Liu, H.; Zheng, J.; Guo, S.; Zhang, J. Graphene quantum dots in photodynamic therapy. Nanoscale Adv. 2020. [CrossRef]

250. Hainfeld, J.F.; Lin, L.; Slatkin, D.N.; Dilmanian, F.A.; Vadas, T.M.; Smilowitz, H.M. Gold nanoparticle hyperthermia reduces radiotherapy dose. Nanomedicine 2014, 10, 1609-1617. [CrossRef] [PubMed]

251. Levi-Polyachenko, N.; Jacob, R.; Day, C.; Kuthirummal, N. Chitosan wound dressing with hexagonal silver nanoparticles for hyperthermia and enhanced delivery of small molecules. Colloids Surfaces B Biointerfaces 2016, 142, 315-324. [CrossRef]

252. Meneses-Brassea, B.P.; Borrego, E.A.; Blazer, D.S.; Sanad, M.F.; Pourmiri, S.; Gutierrez, D.A.; Varela-Ramirez, A.; Hadjipanayis, G.C.; El-Gendy, A.A. Ni-Cu Nanoparticles and Their Feasibility for Magnetic Hyperthermia. Nanomaterials 2020, $10,1988$. [CrossRef]

253. Vetrone, F.; Naccache, R.; Zamarrón, A.; De La Fuente, A.J.; Sanz-Rodríguez, F.; Maestro, L.M.; Rodríguez, E.M.; Jaque, D.; Solé, J.G.; Capobianco, J.A. Temperature Sensing Using Fluorescent Nanothermometers. ACS Nano 2010, 4, 3254-3258. [CrossRef]

254. Yagawa, Y.; Tanigawa, K.; Kobayashi, Y.; Yamamoto, M. Cancer immunity and therapy using hyperthermia with immunotherapy, radiotherapy, chemotherapy, and surgery. J. Cancer Metastasis Treat. 2017, 3, 218. [CrossRef]

255. De Almeida, D.R.Q.; Terra, L.F.; Labriola, L. Photodynamic therapy in cancer treatment-An update review. J. Cancer Metastasis Treat. 2019, 2019. [CrossRef]

256. Aroldi, F.; Lord, S.R.; Aroldi, F.; Lord, S.R. Window of opportunity clinical trial designs to study cancer metabolism. Br. J. Cancer 2019, 122, 45-51. [CrossRef]

257. Vujaskovic, Z.; Song, C.W. Physiological mechanisms underlying heat-induced radiosensitization. Int. J. Hyperth. 2004, 20, 163-174. [CrossRef] [PubMed]

258. Tschoep-Lechner, K.E.; Milani, V.; Berger, F.; Dieterle, N.; Abdel-Rahman, S.; Salat, C.; Issels, R. Gemcitabine and cisplatin combined with regional hyperthermia as second-line treatment in patients with gemcitabine-refractory advanced pancreatic cancer. Int. J. Hyperth. 2012, 29, 8-16. [CrossRef] [PubMed] 
259. Westermann, A.M.; Jones, E.L.; Schem, B.C.; Van Der Steen-Banasik, E.M.; Koper, P.; Mella, O.; Uitterhoeve, A.L.J.; De Wit, R.; Van Der Velden, J.; Burger, C.; et al. First results of triple-modality treatment combining radiotherapy, chemotherapy, and hyperthermia for the treatment of patients with Stage IIB, III, and IVA cervical carcinoma. Cancer. 2005, 104, 763-770. [CrossRef]

260. Westermann, A.; Mella, O.; Van Der Zee, J.; Jones, E.L.; Van Der Steen-Banasik, E.; Koper, P.; Uitterhoeve, A.L.; De Wit, R.; Van Der Velden, J.; Burger, C.; et al. Long-term survival data of triple modality treatment of stage IIB-III-IVA cervical cancer with the combination of radiotherapy, chemotherapy and hyperthermia-An update. Int. J. Hyperth. 2012, 28, 549-553. [CrossRef]

261. Weinberg, B.D.; Allison, R.R.; Sibata, C.; Parent, T.; Downie, G. Results of combined photodynamic therapy (PDT) and high dose rate brachytherapy (HDR) in treatment of obstructive endobronchial non-small cell lung cancer (NSCLC). Photodiagnosis Photodyn. Ther. 2010, 7, 50-58. [CrossRef]

262. Zschaeck, S. Moderate Whole Body Hyperthermia for Patients Undergoing Re-irradiation for Head and Neck Cancer-Influence on the Tumor Microenvironment (GKH-TMM); Charite University: Berlin, Germany, 2018. Available online: https://clinicaltrials.gov/ct2 / show / NCT03547388 (accessed on 26 April 2021).

263. Rogasch, J.; Beck, M.; Stromberger, C.; Hofheinz, F.; Ghadjar, P.; Wust, P.; Budach, V.; Amthauer, H.; Tinhofer, I.; Furth, C.; et al. PET measured hypoxia and MRI parameters in re-irradiated head and neck squamous cell carcinomas: Findings of a prospective pilot study. F1000Research 2020, 9, 1350. [CrossRef] [PubMed]

264. Zschaeck, S.; Weingärtner, J.; Ghadjar, P.; Wust, P.; Mehrhof, F.; Kalinauskaite, G.; Ehrhardt, V.H.; Hartmann, V.; Tinhofer, I.; Heiland, M.; et al. Fever range whole body hyperthermia for re-irradiation of head and neck squamous cell carcinomas: Final results of a prospective study. Oral Oncol. 2021, 116, 105240. [CrossRef] [PubMed]

265. Senthil, M. Adjuvant Hyperthermic Intraperitoneal Chemotherapy for Locally Advanced Gastric Cancer. Loma Linda University; 2016. Available online: https:/ / clinicaltrials.gov/ct2/show / NCT02672865 (accessed on 26 April 2021).

266. Vujaskovic, Z.; Inman, B.A. Mitomycin C with Hyperthermia and Intravesical Mitomycin C to Treat Recurrent Bladder Cancer. Mark Dewhirst; 2008. Available online: https://clinicaltrials.gov/ct2/show/NCT00734994 (accessed on 26 April 2021).

267. Inman, B.A.; Stauffer, P.; Craciunescu, O.A.; Maccarini, P.F.; Dewhirst, M.W.; Vujaskovic, Z. A pilot clinical trial of intravesical mitomycin- $C$ and external deep pelvic hyperthermia for non-muscle-invasive bladder cancer. Int. J. Hyperth. 2014, 30, 171-175. [CrossRef] [PubMed]

268. Stewart, J.H. Intraperitoneal Hyperthermic Perfusion with Oxaliplatin in Treating Patients with Stage IV Peritoneal Cancer Due to Appendix Cancer or Colorectal Cancer. Wake Forest University Health Sciences; 2007. Available online: https://clinicaltrials. gov/ct2/show / NCT00458809 (accessed on 26 April 2021).

269. Iv, J.H.S.; Shen, P.; Russell, G.; Rn, J.F.; Bs, L.M.; Ms, F.M.C.; Levine, K.; Jones, B.T.; Levine, E.A. A Phase I Trial of Oxaliplatin for Intraperitoneal Hyperthermic Chemoperfusion for the Treatment of Peritoneal Surface Dissemination from Colorectal and Appendiceal Cancers. Ann. Surg. Oncol. 2008, 15, 2137-2145. [CrossRef]

270. Tuttle, T.M. Hyperthermic Intraperitoneal Oxaliplatin for Peritoneal Malignancies. Masonic Cancer Center, University of Minnesota; 2008. Available online: https:/ / clinicaltrials.gov/ct2/show / NCT00625092 (accessed on 26 April 2021).

271. Schrump, D.S. Paclitaxel and Hyperthermic Perfusion in Treating Patients with Lung Cancer or Lung Metastases That Cannot Be Re moved By Surgery; NCT00020007 National Cancer Institute (NCI): Bethesda, MD, USA, 2003. Available online: https://clinicaltrials.gov/ ct2/show / NCT00020007 (accessed on 26 April 2021).

272. Middleton, M.R. Targeted Chemotherapy Using Focused Ultrasound for Liver Tumours (TARDOX). University of Oxford; 2014. Available online: https: / / clinicaltrials.gov/ct2/show /NCT02181075 (accessed on 26 April 2021).

273. Lyon, P.C.; Griffiths, L.F.; Lee, J.; Chung, D.; Carlisle, R.; Wu, F.; Middleton, M.R.; Gleeson, F.V.; Coussios, C.C. Clinical trial protocol for TARDOX: A phase I study to investigate the feasibility of targeted release of lyso-thermosensitive liposomal doxorubicin (ThermoDox ${ }^{\circledR}$ ) using focused ultrasound in patients with liver tumours. J. Ther. Ultrasound 2017, 5, 1-8. [CrossRef]

274. Gray, M.D.; Lyon, P.C.; Mannaris, C.; Folkes, L.K.; Stratford, M.; Campo, L.; Chung, D.Y.F.; Scott, S.; Anderson, M.; Goldin, R.; et al. Focused Ultrasound Hyperthermia for Targeted Drug Release from Thermosensitive Liposomes: Results from a Phase I Trial. Radiology 2019, 291, 232-238. [CrossRef]

275. Lyon, P.C.; Gray, M.D.; Mannaris, C.; Folkes, L.K.; Stratford, M.; Campo, L.; Chung, D.Y.F.; Scott, S.; Anderson, M.; Goldin, R.; et al. Safety and feasibility of ultrasound-triggered targeted drug delivery of doxorubicin from thermosensitive liposomes in liver tumours (TARDOX): A single-centre, open-label, phase 1 trial. Lancet Oncol. 2018, 19, 1027-1039. [CrossRef]

276. Dose Escalation of Cisplatin Hyperthermic Intraperitoneal Chemotherapy after Surgery in Patients with Unresec-table Stage IIIC Ovarian, Tube or Peritoneal Primary Adenocarcinoma (CHIPASTIN). Gustave Roussy, Cancer Campus, Grand Paris; 2014. Available online: https:/ / clinicaltrials.gov/ct2/show /NCT02217956 (accessed on 26 April 2021).

277. Gouy, S.; Ferron, G.; Glehen, O.; Bayar, A.; Marchal, F.; Pomel, C.; Quenet, F.; Bereder, J.; Le Deley, M.-C.; Morice, P. Results of a multicenter phase I dose-finding trial of hyperthermic intraperitoneal cisplatin after neoadjuvant chemotherapy and complete cytoreductive surgery and followed by maintenance bevacizumab in initially unresectable ovarian cancer. Gynecol. Oncol. 2016, 142, 237-242. [CrossRef]

278. Ou, J. Safety and Efficacy of Vitamin C Infusion in Combination with Local mEHT to Treat. Non Small Cell Lung Cancer (VCONSCLC); Clifford Hospital: Guangzhou, China, 2016. Available online: https:/ / clinicaltrials.gov/ct2/show /NCT02655913 (accessed on 26 April 2021). 
279. Ou, J.; Zhu, X.; Lu, Y.; Zhao, C.; Zhang, H.; Wang, X.; Gui, X.; Wang, J.; Zhang, X.; Zhang, T.; et al. The safety and pharmacokinetics of high dose intravenous ascorbic acid synergy with modulated electrohyperthermia in Chinese patients with stage III-IV nonsmall cell lung cancer. Eur. J. Pharm. Sci. 2017, 109, 412-418. [CrossRef]

280. Ou, J.; Zhu, X.; Chen, P.; Du, Y.; Lu, Y.; Peng, X.; Bao, S.; Wang, J.; Zhang, X.; Zhang, T.; et al. A randomized phase II trial of best supportive care with or without hyperthermia and vitamin $\mathrm{C}$ for heavily pretreated, advanced, refractory non-small-cell lung cancer. J. Adv. Res. 2020, 24, 175-182. [CrossRef] [PubMed]

281. Blackwell, K.L. Temperature-Sensitive Liposomal Doxorubicin and Hyperthermia in Treating Women with Locally Recurrent Breast Cancer. Duke University; 2006. Available online: https:/ / clinicaltrials.gov/ct2/show / NCT00346229 (accessed on 26 April 2021).

282. Borys, N. Phase $1 / 2$ Study of ThermoDox with Approved Hyperthermia in Treatment of Breast Cancer Recurrence at the Chest Wall (DIGNITY). Celsion; 2009. Available online: https: / www.clinicaltrials.gov/ct2/show / NCT00826085 (accessed on 26 April 2021).

283. Zagar, T.M.; Vujaskovic, Z.; Formenti, S.; Rugo, H.; Muggia, F.; O’Connor, B.; Myerson, R.; Stauffer, P.; Hsu, I.-C.; Diederich, C.; et al. Two phase I dose-escalation/pharmacokinetics studies of low temperature liposomal doxorubicin (LTLD) and mild local hyperthermia in heavily pretreated patients with local regionally recurrent breast cancer. Int. J. Hyperth. 2014, 30, 285-294. [CrossRef]

284. Deraco, M. Adjuvant HIPEC to Prevent Colorectal Peritoneal Metastases in High-risk Patients; Fondazione IRCCS Istituto Nazionale dei Tumori: Milano, Italy, 2015. Available online: https://clinicaltrials.gov/ct2/show/NCT02575859 (accessed on 26 April 2021).

285. Baratti, D.; Kusamura, S.; Iusco, D.; Gimondi, S.; Pietrantonio, F.; Milione, M.; Guaglio, M.; Bonomi, S.; Grassi, A.; Virzì, S.; et al. Hyperthermic Intraperitoneal Chemotherapy (HIPEC) at the Time of Primary Curative Surgery in Patients with Colorectal Cancer at High Risk for Metachronous Peritoneal Metastases. Ann. Surg. Oncol. 2016, 24, 167-175. [CrossRef] [PubMed]

286. Treatment of Primary Peritoneal Carcinosis of Digestive Origin Using Cytoreductive Surgery and Hyperthermic Intraoperative Peritoneal Chemotherapy with Mitomycin C and Irinotecan. Hospices Civils de Lyon; 2010. Available online: https: / clinicaltrials. gov/ct2/show / NCT01226550 (accessed on 26 April 2021).

287. Jones, E.L.; Vujaskovic, Z. MRI Sarcoma Non Invasive Thermometry. Mark Dewhirst; 2004. Available online: https:/ clinicaltrials gov/ct2/show / NCT00093509 (accessed on 26 April 2021).

288. Craciunescu, O.I.; Stauffer, P.R.; Soher, B.J.; Wyatt, C.R.; Arabe, O.; Maccarini, P.; Das, S.K.; Cheng, K.-S.; Wong, T.Z.; Jones, E.L.; et al. Accuracy of real time noninvasive temperature measurements using magnetic resonance thermal imaging in patients treated for high grade extremity soft tissue sarcomas. Med. Phys. 2009, 36, 4848-4858. [CrossRef] [PubMed]

289. Kerger, J.; Goffin, F. Feasibility Study of HIPEC for Patients with Stage III or Only Pleural Stage IV Ovarian Carcinoma in First Line Therapy. Jules Bordet Institute; 2012. Available online: https:/ / clinicaltrials.gov/ct2/show / NCT01709487 (accessed on 26 April 2021).

290. D’Hondt, V.; Goffin, F.; Roca, L.L.; Dresse, D.D.; Leroy, C.; Kerger, J.; Cordier, L.L.; De Forges, H.H.; Veys, I.; Liberale, G. Interval Cytoreductive Surgery and Hyperthermic Intraperitoneal Chemotherapy in First-Line Treatment for Advanced Ovarian Carcinoma: A Feasibility Study. Int. J. Gynecol. Cancer 2016, 26, 912-917. [CrossRef] [PubMed]

291. Xiong, B. Radical Colorectal Resection and Hyperthermic Intraperitoneal Chemotherapy (HIPEC) in Locally Advanced Colorectal Cancer. Wuhan University; 2016. Available online: https:/ / clinicaltrials.gov/ct2/show / NCT02830139 (accessed on 26 April 2021).

292. Xiong, B. Radical Gastrectomy and Hyperthermic Intraperitoneal Chemotherapy (HIPEC) in Locally Advanced Gastric Cancer. Wuhan University; 2015. Available online: https:/ / linicaltrials.gov/ct2/show/NCT02528110 (accessed on 26 April 2021).

293. Preoperative Radiochemotherapy with Hyperthermia for Locally Advanced Rectal Cancer (HT01). University Hospital Tuebingen; 2015. Available online: https://clinicaltrials.gov/ct2/show /NCT02353858 (accessed on 26 April 2021).

294. Gani, C.; Lamprecht, U.; Ziegler, A.; Moll, M.; Gellermann, J.; Heinrich, V.; Wenz, S.; Fend, F.; Königsrainer, A.; Bitzer, M.; et al. Deep regional hyperthermia with preoperative radiochemotherapy in locally advanced rectal cancer, a prospective phase II trial. Radiother. Oncol. 2021, 159, 155-160. [CrossRef]

295. Badgwell, B. Laparoscopic Hyperthermic Intraperitoneal Chemoperfusion (HIPEC) for Metastatic Gastric Cancer. M.D. Anderson Cancer Center; 2014. Available online: https://clinicaltrials.gov/ct2/show /NCT02092298 (accessed on 26 April 2021).

296. Badgwell, B.; Blum, M.; Das, P.; Estrella, J.; Wang, X.; Fournier, K.; Royal, R.; Mansfield, P.; Ajani, J. Lessons learned from a phase II clinical trial of laparoscopic HIPEC for gastric cancer. Surg. Endosc. 2017, 32, 512. [CrossRef]

297. Badgwell, B.; Blum, M.; Das, P.; Estrella, J.; Wang, X.; Ho, L.; Fournier, K.; Royal, R.; Mansfield, P.; Ajani, J. Phase II Trial of Laparoscopic Hyperthermic Intraperitoneal Chemoperfusion for Peritoneal Carcinomatosis or Positive Peritoneal Cytology in Patients with Gastric Adenocarcinoma. Ann. Surg. Oncol. 2017, 24, 3338-3344. [CrossRef] [PubMed]

298. Kaplan, I.D. Hyperthermia Plus Radiation Therapy in Treating Patients with Nonmetastatic Advanced Prostate Cancer. DanaFarber Cancer Institute; 2003. Available online: https:/ / clinicaltrials.gov/ct2/show / NCT00003045 (accessed on 26 April 2021).

299. Hurwitz, M.D.; Ms, J.L.H.; Prokopios-Davos, S.; Manola, J.; Wang, Q.; Bornstein, B.A.; Hynynen, K.; Kaplan, I.D. Hyperthermia combined with radiation for the treatment of locally advanced prostate cancer. Cancer 2010, 117, 510-516. [CrossRef] [PubMed]

300. Hayes-Jordan, A. Pilot Study of Hyperthermic Peritoneal Perfusion (HIPEC) for Adolescent and Young Adults with Desmoplastic Small Round Cell Tumor. M.D. Anderson Cancer Center; 2011. Available online: https://clinicaltrials.gov/ct2/show / NCT01277 744 (accessed on 26 April 2021). 
301. Hayes-Jordan, A.A.; Coakley, B.A.; Green, H.L.; Xiao, L.; Fournier, K.F.; Herzog, C.E.; Ludwig, J.A.; McAleer, M.F.; Anderson, P.M.; Huh, W.W. Desmoplastic Small Round Cell Tumor Treated with Cytoreductive Surgery and Hyperthermic Intraperitoneal Chemotherapy: Results of a Phase 2 Trial. Ann. Surg. Oncol. 2018, 25, 872-877. [CrossRef]

302. Mahteme, H. Neo-adjuvant Chemo + Peritonectomy + Hyperthermic Intraperitoneal Chemo in Peritoneal Carcinomatosis From Gastric Cancer. Uppsala University; 2011. Available online: https:/ / clinicaltrials.gov/ct2/show / NCT01379482 (accessed on 26 April 2021).

303. Hultman, B.; Lind, P.; Glimelius, B.; Sundbom, M.; Nygren, P.; Haglund, U.; Mahteme, H. Phase II study of patients with peritoneal carcinomatosis from gastric cancer treated with preoperative systemic chemotherapy followed by peritonectomy and intraperitoneal chemotherapy. Acta Oncol. 2012, 52, 824-830. [CrossRef]

304. In, H. Single Arm Study Treating Patients of Peritoneal Surface Malignancy (Colorectal, Appendical, Pseudomyxoma, Gastric) with Cytoreductive Surgery and Hyperthermic Intraperitoneal Mitomycin-C. Albert Einstein College of Medicine; 2014. Available online: https: / / clinicaltrials.gov/ct2/show / NCT02040142 (accessed on 26 April 2021).

305. Davis, J.L. Surgery and Heated Chemotherapy for Adrenocortical Carcinoma. National Cancer Institute (NCI); 2013. Available online: https: / / clinicaltrials.gov/ct2/show / NCT01833832 (accessed on 26 April 2021).

306. Hughes, M.S.; Lo, W.M.; Beresnev, T.; Merino, M.; Shutack, Y.; Ripley, R.T.; Hernandez, J.M.; Davis, J.L. A Phase II Trial of Cytoreduction and Hyperthermic Intraperitoneal Chemotherapy for Recurrent Adrenocortical Carcinoma. J. Surg. Res. 2018, 232, 383-388. [CrossRef]

307. Shen, P. Thalidomide in Treating Patients Who Have Undergone Surgery and Chemotherapy for Cancer That Has Spread Throughout the Abdomen Due to Colorectal Cancer or Appendix Cancer. Wake Forest University Health Sciences; 2006. Available online: https: / / clinicaltrials.gov/ct2/show / NCT00310076 (accessed on 26 April 2021).

308. Shen, P.; Thomas, C.R.; Fenstermaker, J.; Aklilu, M.; McCoy, T.P.; Levine, E.A. Phase II trial of adjuvant oral thalidomide following cytoreductive surgery and hyperthermic intraperitoneal chemotherapy for peritoneal surface disease from colorectal/appendiceal cancer. J. Gastrointest. Cancer 2014, 45, 268-275. [CrossRef] [PubMed]

309. Robins, H.I. Whole-Body Hyperthermia Plus Chemotherapy in Treating Patients with Advanced Sarcoma; University of Wisconsin: Madison, WI, USA. Available online: https:/ clinicaltrials.gov/ct2/show/NCT00002974 (accessed on 26 April 2021).

310. Robins, H.I. Melphalan and Whole-Body Hyperthermia in Treating Patients with Advanced Melanoma; University of Wisconsin: Madison, WI, USA, 2004. Available online: https:/ / clinicaltrials.gov/ct2/show /NCT00002973 (accessed on 26 April 2021).

311. Park, S.-Y. Intraoperative Hyperthermic Intraperitoneal Chemotherapy with Ovarian Cancer; National Cancer Center: Korea, 2010. Available online: https: / / clinicaltrials.gov/ct2/show /NCT01091636 (accessed on 26 April 2021).

312. Lim, M.C.; Chang, S.-J.; Yoo, H.J.; Nam, B.-H.; Bristow, R.; Park, S.-Y. Randomized trial of hyperthermic intraperitoneal chemotherapy (HIPEC) in women with primary advanced peritoneal, ovarian, and tubal cancer. J. Clin. Oncol. 2017, $35,5520$. [CrossRef]

313. Żółciak-Siwińska, A. Hyperthermia Combined Brachytherapy in CCU. Maria Sklodowska-Curie Institute-Oncology Center; 2011. Available online: https:/ / clinicaltrials.gov/ct2/show / NCT01474356 (accessed on 26 April 2021).

314. Żółciak-Siwińska, A.; Piotrkowicz, N.; Jonska-Gmyrek, J.; Nicke-Psikuta, M.; Michalski, W.; Kawczyńska, M.; Bijok, M.; Bujko, K. HDR brachytherapy combined with interstitial hyperthermia in locally advanced cervical cancer patients initially treated with concomitant radiochemotherapy-A phase III study. Radiother. Oncol. 2013, 109, 194-199. [CrossRef]

315. Quenet, F. Systemic Chemotherapy with or without Intraperitoneal Chemohyperthermia in Treating Patients Undergoing Surgery for Peritoneal Carcinomatosis From Colorectal Cancer. UNICANCER; 2008. Available online: https://clinicaltrials.gov/ct2 / show / NCT00769405 (accessed on 26 April 2021).

316. Quénet, F.; Elias, D.; Roca, L.; Goéré, D.; Ghouti, L.; Pocard, M.; Facy, O.; Arvieux, C.; Lorimier, G.; Pezet, D.; et al. Cytoreductive surgery plus hyperthermic intraperitoneal chemotherapy versus cytoreductive surgery alone for colorectal peritoneal metastases (PRODIGE 7): A multicentre, randomised, open-label, phase 3 trial. Lancet Oncol. 2021, 22, 256-266. [CrossRef]

317. van Driel, W.J. Secondary Debulking Surgery +/- Hyperthermic Intraperitoneal Chemotherapy in Stage III Ovarian Cancer. The Netherlands Cancer Institute; 2007. Available online: https:/ / clinicaltrials.gov/ct2/show / NCT00426257 (accessed on 26 April 2021).

318. Van Driel, W.J.; Koole, S.N.; Sikorska, K.; Van Leeuwen, J.H.S.; Schreuder, H.W.; Hermans, R.H.; De Hingh, I.H.; Van Der Velden, J.; Arts, H.J.; Massuger, L.F.; et al. Hyperthermic Intraperitoneal Chemotherapy in Ovarian Cancer. N. Engl. J. Med. 2018, 378, 230-240. [CrossRef] [PubMed]

319. Koole, S.N.; Van Lieshout, C.; Van Driel, W.J.; Van Schagen, E.; Sikorska, K.; Kieffer, J.M.; Van Leeuwen, J.H.S.; Schreuder, H.W.; Hermans, R.H.; De Hingh, I.H.; et al. Cost Effectiveness of Interval Cytoreductive Surgery with Hyperthermic Intraperitoneal Chemotherapy in Stage III Ovarian Cancer on the Basis of a Randomized Phase III Trial. J. Clin. Oncol. 2019, 37, $2041-2050$. [CrossRef]

320. Van Driel, W.; Sikorska, K.; Van Leeuwen, J.S.; Schreuder, H.; Hermans, R.; De Hingh, I.; Van Der Velden, J.; Arts, H.J.; Leon, M.; Aalbers, A.; et al. A phase 3 trial of hyperthermic intraperitoneal chemotherapy (HIPEC) for ovarian cancer. J. Clin. Oncol. 2017, 35, 5519. [CrossRef]

321. Issels, R.D. Combination Chemotherapy with or without Hyperthermia Therapy in Treating Patients with Soft Tissue Sarcoma. European Organisation for Research and Treatment of Cancer-EORTC; 2003. Available online: https://clinicaltrials.gov/ct2 /show / NCT00003052 (accessed on 26 April 2021). 
322. Issels, R.D.; Lindner, L.H.; Verweij, J.; Wessalowski, R.; Reichardt, P.; Wust, P.; Ghadjar, P.; Hohenberger, P.; Angele, M.; Salat, C.; et al. Effect of Neoadjuvant Chemotherapy Plus Regional Hyperthermia on Long-term Outcomes Among Patients with Localized High-Risk Soft Tissue Sarcoma. JAMA Oncol. 2018, 4, 483-492. [CrossRef]

323. Knösel, T.; Altendorf-Hofmann, A.; Lindner, L.; Issels, R.; Hermeking, H.; Schuebbe, G.; Gibis, S.; Siemens, H.; Kampmann, E.; Kirchner, T. Loss of p16(INK4a) is associated with reduced patient survival in soft tissue tumours, and indicates a senescence barrier. J. Clin. Pathol. 2014, 67, 592-598. [CrossRef] [PubMed]

324. Hsu, I.C. Pilot Study of a Catheter-Based Ultrasound Hyperthermia System; University of California: San Francisco, CA, USA, 2009. Available online: https:/ / clinicaltrials.gov/ct2/show/NCT00911079 (accessed on 26 April 2021).

325. Diederich, C.; Wootton, J.; Prakash, P.; Salgaonkar, V.; Juang, T.; Scott, S.; Chen, X.; Cunha, A.; Pouliot, J.; Hsu, I.C.; et al. A Pilot Study of Catheter-Based Ultrasound Hyperthermia with HDR Brachytherapy for Treatment of Locally Advanced Cancer of the Prostate and Cervix. AIP Conf. Proc. 1359 2011, 195-199. [CrossRef]

326. Demirtas, A. Intravesical Thermochemotherapy with Mitomycinc. TC Erciyes University; 2018. Available online: https: / / clinicaltrials.gov/ct2/show / NCT03694535 (accessed on 26 April 2021).

327. Demirtaş, A.; Tombul, T.; Sönmez, G.; Demirleğen, A.; Demirtaş, T.; Tatlışen, A. Intravesical Mitomycin-C with Bladder Wall Hyperthermia in Intermediate and High-risk Non-muscle Invasive Bladder Cancers: Prospective Clinical Trial with a Singletreatment Arm. Bull. Urooncology 2020, 19, 182-185. [CrossRef]

328. Marsh, M. Photodynamic Therapy and Vismodegib for Multiple Basal Cell Carcinomas (PDT-Vismo). University of Arizona; 2015. Available online: https:/ / clinicaltrials.gov/ct2/show/NCT02639117 (accessed on 26 April 2021).

329. Rizzo, J.M.; Segal, R.J.; Zeitouni, N.C. Combination vismodegib and photodynamic therapy for multiple basal cell carcinomas. Photodiagnosis Photodyn. Ther. 2018, 21, 58-62. [CrossRef]

330. DeWitt, J.M. Ultrasound-Guided Photodynamic Therapy with Photofrin \& Gemcitabine for Patients with Locally Advanced Pancreatic Cancer. 2013. Available online: https:/ / clinicaltrials.gov/ct2/show/NCT01770132 (accessed on 26 April 2021).

331. DeWitt, J.M.; Sandrasegaran, K.; O’Neil, B.; House, M.G.; Zyromski, N.J.; Sehdev, A.; Perkins, S.M.; Flynn, J.; McCranor, L.; Shahda, S. Phase 1 study of EUS-guided photodynamic therapy for locally advanced pancreatic cancer. Gastrointest. Endosc. 2019, 89, 390-398. [CrossRef] [PubMed]

332. Nwogu, C. Photodynamic Therapy During Surgery in Treating Patients with Non-small Cell Lung Cancer That Can Be Removed by Surgery. Roswell Park Cancer Institute; 2013. Available online: https: / / clinicaltrials.gov/ct2/show/NCT01854684 (accessed on 26 April 2021).

333. Arshad, H. Photodynamic Therapy Using HPPH in Treating Patients Undergoing Surgery for Primary or Recurrent Head and Neck Cancer. Roswell Park Cancer Institute; 2007. Available online: https:/ / www.clinicaltrials.gov / ct2/show / NCT00470496 (accessed on 26 April 2021).

334. Rigual, N.R.; Shafirstein, G.; Frustino, J.; Seshadri, M.; Cooper, M.; Wilding, G.; Sullivan, M.A.; Henderson, B. Adjuvant Intraoperative Photodynamic Therapy in Head and Neck Cancer. JAMA Otolaryngol. Head Neck Surg. 2013, 139, 706. [CrossRef]

335. Loewen, G.M. Photodynamic Therapy Plus Brachytherapy in Treating Patients with Lung Cancer. Roswell Park Cancer Institute; 2004. Available online: https:/ / clinicaltrials.gov/ct2/show /NCT00014066 (accessed on 26 April 2021).

336. Wang, K.K. Endoscopic Therapy of Early Cancer in Barretts Esophagus. Mayo Clinic; 2005. Available online: https://clinicaltrials. gov/ct2/show / NCT00217087 (accessed on 26 April 2021).

337. Demmy, T.L. Surgery and Photodynamic Therapy in Treating Patients with Malignant Mesothelioma. Roswell Park Cancer Institute; 2003. Available online: https:/ / clinicaltrials.gov / ct2/show / NCT00054002 (accessed on 26 April 2021).

338. Oseroff, A.R. Photodynamic Therapy in Treating Patients with Skin Cancer. Roswell Park Cancer Institute; 2003. Available online: https: / clinicaltrials.gov/ct2/show/NCT00002963 (accessed on 26 April 2021).

339. Park, D.H. S-1 and Photodynamic Therapy in Cholangiocarcinoma. Asan Medical Center, 209AD. Available online: https: / / clinicaltrials.gov/ct2/show / NCT00869635 (accessed on 26 April 2021).

340. Park, D.H.; Lee, S.S.; Park, S.E.; Lee, J.L.; Choi, J.H.; Choi, H.J.; Jang, J.W.; Kim, H.J.; Eum, J.B.; Seo, D.-W.; et al. Randomised phase II trial of photodynamic therapy plus oral fluoropyrimidine, S-1, versus photodynamic therapy alone for unresectable hilar cholangiocarcinoma. Eur. J. Cancer 2014, 50, 1259-1268. [CrossRef] [PubMed]

341. Krzykawska-Serda, M.; Agha, M.S.; Ho, J.C.-S.; Ware, M.J.; Law, J.J.; Newton, J.M.; Nguyen, L.; Curley, S.A.; Corr, S.J. Chemotherapy and Radiofrequency-Induced Mild Hyperthermia Combined Treatment of Orthotopic Pancreatic Ductal Adenocarcinoma Xenografts. Transl. Oncol. 2018, 11, 664-671. [CrossRef]

342. Krzykawska-Serda, M.; Ho, J.C.-S.; Ware, M.J.; Law, J.J.; Newton, J.M.; Nguyen, L.; Agha, M.; Curley, S.A.; Corr, S.J. Ultrasound Doppler as an Imaging Modality for Selection of Murine 4T1 Breast Tumors for Combination Radiofrequency Hyperthermia and Chemotherapy. Transl. Oncol. 2018, 11, 864-872. [CrossRef] [PubMed]

343. Brodin, N.P.; Guha, C.; Tomé, W.A. Photodynamic Therapy and Its Role in Combined Modality Anticancer Treatment. Technol. Cancer Res. Treat. 2014, 14, 355-368. [CrossRef] [PubMed]

344. Lovell, J.; Liu, T.; Chen, J.; Zheng, G. Activatable Photosensitizers for Imaging and Therapy. Chem. Rev. 2010, 110, $2839-2857$. [CrossRef] [PubMed]

345. Jha, S.; Sharma, P.K.; Malviya, R. Hyperthermia: Role and Risk Factor for Cancer Treatment. Achiev. Life Sci. 2016, 10, 161-167. [CrossRef] 
346. Anand, S.; Ortel, B.J.; Pereira, S.; Hasan, T.; Maytin, E.V. Biomodulatory approaches to photodynamic therapy for solid tumors. Cancer Lett. 2012, 326, 8-16. [CrossRef]

347. Kok, H.P.; Cressman, E.N.K.; Ceelen, W.; Brace, C.L.; Ivkov, R.; Grüll, H.; Ter Haar, G.; Wust, P.; Crezee, J. Heating technology for malignant tumors: A review. Int. J. Hyperth. 2020, 37, 711-741. [CrossRef]

348. Yanovsky, R.L.; Bartenstein, D.W.; Rogers, G.S.; Isakoff, S.J.; Chen, S.T. Photodynamic therapy for solid tumors: A review of the literature. Photodermatol. Photoimmunol. Photomed. 2019, 35, 295-303. [CrossRef] [PubMed]

349. Cosst, R.A.; Linnemans, W.A.M. The effects of hyperthermia on the cytoskeleton. Int. J. Hyperth. 1996, 12, 173-196. [CrossRef]

350. Kong, G.; Braun, R.D.; Dewhirst, M.W. Hyperthermia enables tumor-specific nanoparticle delivery: Effect of particle size. Cancer Res. 2000, 60, 4440-4445. [PubMed]

351. Mokwena, M.G.; Kruger, C.A.; Ivan, M.-T.; Heidi, A. A review of nanoparticle photosensitizer drug delivery uptake systems for photodynamic treatment of lung cancer. Photodiagnosis Photodyn. Ther. 2018, 22, 147-154. [CrossRef]

352. Crescenzi, E.; Chiaviello, A.; Canti, G.; Reddi, E.; Veneziani, B.M.; Palumbo, G. Low doses of cisplatin or gemcitabine plus Photofrin/photodynamic therapy: Disjointed cell cycle phase-related activity accounts for synergistic outcome in metastatic non-small cell lung cancer cells (H1299). Mol. Cancer Ther. 2006, 5, 776-785. [CrossRef] [PubMed]

353. Tsang, Y.-W.; Chi, K.-H.; Huang, C.-C.; Chi, M.-S.; Chiang, H.-C.; Yang, K.-L.; Li, W.-T.; Wang, Y.-S. Modulated electrohyperthermia-enhanced liposomal drug uptake by cancer cells. Int. J. Nanomed. 2019, 14, 1269-1279. [CrossRef] [PubMed]

354. Zhao, J.; Xie, P.; Ye, C.; Wu, C.; Han, W.; Huang, M.; Wang, S.; Chen, H. Outside-in synthesis of mesoporous silica/molybdenum disulfide nanoparticles for antitumor application. Chem. Eng. J. 2018, 351, 157-168. [CrossRef]

355. Markezana, A.; Ahmed, M.; Kumar, G.; Zorde-Khvalevsky, E.; Rozenblum, N.; Galun, E.; Goldberg, S.N.; Markezana, A.; Ahmed, M.; Kumar, G.; et al. Moderate hyperthermic heating encountered during thermal ablation increases tumor cell activity. Int. J. Hyperth. 2020, 37, 119-129. [CrossRef] [PubMed]

356. Jain, R.K. Normalization of Tumor Vasculature: An Emerging Concept in Antiangiogenic Therapy. Science 2005, 307, 58-62. [CrossRef]

357. Nowak-Sliwinska, P.; Wagnieres, G.; Bergh, H.V.D.; Griffioen, A.W. Angiostasis-induced vascular normalization can improve photodynamic therapy. Cell. Mol. Life Sci. 2010, 67, 1559-1560. [CrossRef]

358. Fabbrini, M.; Trachsel, E.; Soldani, P.; Bindi, S.; Alessi, P.; Bracci, L.; Kosmehl, H.; Zardi, L.; Neri, D.; Neri, P. Selective occlusion of tumor blood vessels by targeted delivery of an antibody-photosensitizer conjugate. Int. J. Cancer 2005, 118, 1805-1813. [CrossRef]

359. Cho, K.; Wang, X.; Nie, S.; Chen, Z.; Shin, D.M. Therapeutic Nanoparticles for Drug Delivery in Cancer. Clin. Cancer Res. 2008, 14, 1310-1316. [CrossRef]

360. Chang, M.-Y.; Shiau, A.-L.; Chen, Y.-H.; Chang, C.-J.; Chen, H.H.-W.; Wu, C.-L. Increased apoptotic potential and dose-enhancing effect of gold nanoparticles in combination with single-dose clinical electron beams on tumor-bearing mice. Cancer Sci. 2008, 99, 1479-1484. [CrossRef] [PubMed]

361. Sawyer, C.A.; Habib, A.H.; Miller, K.; Collier, K.N.; Ondeck, C.L.; McHenry, M.E. Modeling of temperature profile during magnetic thermotherapy for cancer treatment. J. Appl. Phys. 2009, 105, 7. [CrossRef]

362. Cardinal, J.; Klune, J.R.; Chory, E.; Jeyabalan, G.; Kanzius, J.S.; Nalesnik, M.; Geller, D.A. Non-Invasive Radiofrequency Ablation of Cancer Targe. Surgery 2008, 144, 125-132. [CrossRef]

363. Kelleher, D.K.; Bastian, J.; Thews, O.; Vaupel, P.; Kelleher, D.K.; Bastian, J.; Thews, O.; Vaupel, P. Enhanced effects of aminolaevulinic acid-based photodynamic therapy through local hyperthermia in rat tumours. Br. J. Cancer 2003, 89, 405-411. [CrossRef] [PubMed]

364. Kelleher, D.K.; Thews, O.; Scherz, A.; Salomon, Y.; Vaupel, P. Combined hyperthermia and chlorophyll-based photodynamic therapy: Tumour growth and metabolic microenvironment. Br. J. Cancer 2003, 89, 2333-2339. [CrossRef] [PubMed]

365. Li, J.; Wei, K.; Zuo, S.; Xu, Y.; Zha, Z.; Ke, W.; Chen, H.; Ge, Z. Light-Triggered Clustered Vesicles with Self-Supplied Oxygen and Tissue Penetrability for Photodynamic Therapy against Hypoxic Tumor. Adv. Funct. Mater. 2017, 27. [CrossRef]

366. Hu, Q.; Sun, W.; Wang, C.; Gu, Z. Recent advances of cocktail chemotherapy by combination drug delivery systems. Adv. Drug Deliv. Rev. 2016, 98, 19-34. [CrossRef] [PubMed]

367. Baskar, R.; Lee, K.A.; Yeo, R.; Yeoh, K.-W. Cancer and Radiation Therapy: Current Advances and Future Directions. Int. J. Med. Sci. 2012, 9, 193-199. [CrossRef] [PubMed]

368. Jackson, S.P.; Bartek, J. The DNA-damage response in human biology and disease. Nat. Cell Biol. 2009, 461, 1071-1078. [CrossRef] [PubMed]

369. Herskind, C.; Ma, L.; Liu, Q.; Zhang, B.; Schneider, F.; Veldwijk, M.R.; Wenz, F. Biology of high single doses of IORT: RBE, 5 R's, and other biological aspects. Radiat. Oncol. 2017, 12, 24. [CrossRef]

370. Hall, N.; Rouge, B. The physics of proton therapy. Phys. Med. Biol. 2015, 60. [CrossRef]

371. Strojan, P. Role of radiotherapy in melanoma management. Radiol. Oncol. 2010, 44, 1-12. [CrossRef]

372. Dewey, W.C. Arrhenius relationships from the molecule and cell to the clinic. Int. J. Hyperth. 2009, 25, 3-20. [CrossRef] [PubMed]

373. Arruebo, M.; Vilaboa, N.; Sáez-Gutierrez, B.; Lambea, J.; Tres, A.; Valladares, M.; González-Fernández, A. Assessment of the Evolution of Cancer Treatment Therapies. Cancers 2011, 3, 3279-3330. [CrossRef]

374. Morgan, N.Y.; Kramer-Marek, G.; Smith, P.D.; Camphausen, K.; Capala, J. Nanoscintillator Conjugates as Photodynamic Therapy-Based Radiosensitizers: Calculation of Required Physical Parameters. Radiat. Res. 2009, 171, 236-244. [CrossRef]

375. Schaffer, M.; Ertl-Wagner, B.; Kulka, U.; Jori, G.; Duhmke, E.; Hofstetter, A.; Schaffer, P.M. The Application of Photofrin II ${ }^{\circledR}$ as a Sensitizing Agent for Ionizing Radiation-A New Approach in Tumor Therapy? Curr. Med. Chem. 2005, 12, 1209-1215. [CrossRef] 
376. Luksiene, Z.; Kalvelyte, A.; Supino, R. On the combination of photodynamic therapy with ionizing radiation. J. Photochem. Photobiol. B Biol. 1999, 52, 35-42. [CrossRef]

377. Schirrmacher, V. From chemotherapy to biological therapy: A review of novel concepts to reduce the side effects of systemic cancer treatment (Review). Int. J. Oncol. 2018, 54, 407-419. [CrossRef] [PubMed]

378. Phung, D.C.; Nguyen, H.T.; Tran, T.T.P.; Jin, S.G.; Yong, C.S.; Truong, D.H.; Tran, T.H.; Kim, J.O. Combined hyperthermia and chemotherapy as a synergistic anticancer treatment. J. Pharm. Investig. 2019, 49, 519-526. [CrossRef]

379. Cheng, L.; Wang, C.; Feng, L.; Yang, K.; Liu, Z. Functional Nanomaterials for Phototherapies of Cancer. Chem. Rev. 2014, 114, 10869-10939. [CrossRef] [PubMed]

380. Song, C.W. Effect of local hyperthermia on blood flow and microenvironment: A review. Cancer Res. 1984, 44, 4721s-4730s. [PubMed]

381. Issels, R.D. Hyperthermia adds to chemotherapy. Eur. J. Cancer 2008, 44, 2546-2554. [CrossRef] [PubMed]

382. Bettaieb, A.; Averill-Bates, D.A. Thermotolerance induced at a fever temperature of $40{ }^{\circ} \mathrm{C}$ protects cells against hyperthermiainduced apoptosis mediated by death receptor signalling. Biochem. Cell Biol. 2008, 86, 521-538. [CrossRef]

383. Pawlik, T.M.; Scoggins, C.R.; Zorzi, D.; Abdalla, E.K.; Andres, A.; Eng, C.; Curley, S.A.; Loyer, E.M.; Muratore, A.; Mentha, G.; et al. Effect of Surgical Margin Status on Survival and Site of Recurrence After Hepatic Resection for Colorectal Metastases. Ann. Surg. 2005, 241, 715-724. [CrossRef]

384. Hemming, A.W.; Reed, A.; Langham, M.; Fujita, S.; Howard, R.J. Combined Resection of the Liver and Inferior Vena Cava for Hepatic Malignancy. Ann. Surg. 2004, 239, 712-721. [CrossRef]

385. Ware, M.; Nguyen, L.P.; Law, J.J.; Krzykawska-Serda, M.; Taylor, K.M.; Cao, H.S.T.; Anderson, A.O.; Pulikkathara, M.; Newton, J.M.; Ho, J.C.; et al. A new mild hyperthermia device to treat vascular involvement in cancer surgery. Sci. Rep. 2017, 7, 1-14. [CrossRef] [PubMed]

386. Dixon, K.; Gibbins, S.; Moghissi, K. A Surgical View of Photodynamic Therapy in Oncology: A Review. Surg. J. 2015, 1, e1-e15. [CrossRef] [PubMed]

387. Moghissi, K.; Stringer, M.; Dixon, K. Fluorescence photodiagnosis in clinical practice. Photodiagnosis Photodyn. Ther. 2008, 5, 235-237. [CrossRef] [PubMed]

388. Eljamel, M.S. Fluorescence image-guided surgery of brain tumors: Explained step-by-step. Photodiagnosis Photodyn. Ther. 2008, 5, 260-263. [CrossRef]

389. Höckel, M.; Vaupel, P. Tumor Hypoxia: Definitions and Current Clinical, Biologic, and Molecular Aspects. J. Natl. Cancer Inst. 2001, 93, 266-276. [CrossRef] [PubMed]

390. Span, P.N.; Bussink, J. Biology of hypoxia. Semin. Nucl. Med. 2015, 45, 101-109. [CrossRef]

391. Epel, B.; Maggio, M.C.; Barth, E.D.; Miller, R.C.; Pelizzari, C.A.; Krzykawska-Serda, M.; Sundramoorthy, S.V.; Aydogan, B.; Weichselbaum, R.R.; Tormyshev, V.M.; et al. Oxygen-Guided Radiation Therapy. Int. J. Radiat. Oncol. 2019, 103, 977-984. [CrossRef]

392. Muz, B.; de la Puente, P.; Azab, F.; Azab, A.K. The role of hypoxia in cancer progression, angiogenesis, metastasis, and resistance to therapy. Hypoxia 2015, 3, 83-92. [CrossRef]

393. Carnero, A.; Lleonart, M. The hypoxic microenvironment: A determinant of cancer stem cell evolution. Insid. Cell 2015, 1, 96-105. [CrossRef]

394. Helmlinger, G.; Yuan, F.; Dellian, M.; Jain, R.K. Interstitial $\mathrm{pH}$ and $\mathrm{pO}_{2}$ gradients in solid tumors in vivo: High-resolution measurements reveal a lack of correlation. Nat. Med. 1997, 3, 177-182. [CrossRef]

395. Elming, P.B.; Sørensen, B.S.; Oei, A.L.; Franken, N.A.; Crezee, J.; Overgaard, J.; Horsman, M.R. Hyperthermia: The Optimal Treatment to Overcome Radiation Resistant Hypoxia. Cancers 2019, 11, 60. [CrossRef]

396. Sierra, H.; Cordova, M.; Chen, C.-S.J.; Rajadhyaksha, M. Confocal Imaging-Guided Laser Ablation of Basal Cell Carcinomas: An Ex Vivo Study. J. Investig. Dermatol. 2015, 135, 612-615. [CrossRef]

397. Azad, M.; Chen, Y.; Henson, E.S.; Cizeau, J.; McMillan-Ward, E.; Israels, S.J.; Gibson, S.B. Hypoxia induces autophagic cell death in apoptosis-competent cells through a mechanism involving BNIP3. Autophagy 2008, 4, 195-204. [CrossRef]

398. Lee, J.G.; Shin, J.H.; Shim, H.S.; Lee, C.Y.; Kim, D.J.; Kim, Y.S.; Chung, K.Y. Autophagy contributes to the chemo-resistance of non-small cell lung cancer in hypoxic conditions. Respir. Res. 2015, 16, 1-9. [CrossRef] [PubMed]

399. Harhaji-Trajkovic, L.; Vilimanovich, U.; Kravic-Stevovic, T.; Bumbasirevic, V.; Trajkovic, V. AMPK-mediated autophagy inhibits apoptosis in cisplatin-treated tumour cells. J. Cell. Mol. Med. 2009, 13, 3644-3654. [CrossRef] [PubMed]

400. Govaert, K.M.; Emmink, B.L.; Nijkamp, M.W.; Cheung, Z.J.; Steller, E.J.A.; Fatrai, S.; de Bruijn, M.T.; Kranenburg, O.; Rinkes, I.H.M.B. Hypoxia After Liver Surgery Imposes an Aggressive Cancer Stem Cell Phenotype on Residual Tumor Cells. Ann. Surg. 2014, 259, 750-759. [CrossRef]

401. Rey, S.; Schito, L.; Koritzinsky, M.; Wouters, B.G. Molecular targeting of hypoxia in radiotherapy. Adv. Drug Deliv. Rev. 2017, 109, 45-62. [CrossRef] [PubMed]

402. Moeller, B.J.; Richardson, R.A.; Dewhirst, M.W. Hypoxia and radiotherapy: Opportunities for improved outcomes in cancer treatment. Cancer Metastasis Rev. 2007, 26, 241-248. [CrossRef] [PubMed]

403. Garg, A.; Nowis, D.; Golab, J.; Agostinis, P. Photodynamic therapy: Illuminating the road from cell death towards anti-tumour immunity. Apoptosis 2010, 15, 1050-1071. [CrossRef]

404. Chen, B.; Roskams, T.; de Witte, P. Enhancing the antitumoral effect of hypericin-mediated photodynamic therapy by hyperthermia. Lasers Surg. Med. 2002, 31, 158-163. [CrossRef] 